Prepared in cooperation with the

New York City Department of Environmental Protection

\title{
Groundwater-Level Data From an Earthen Dam Site in Southern Westchester County, New York
}

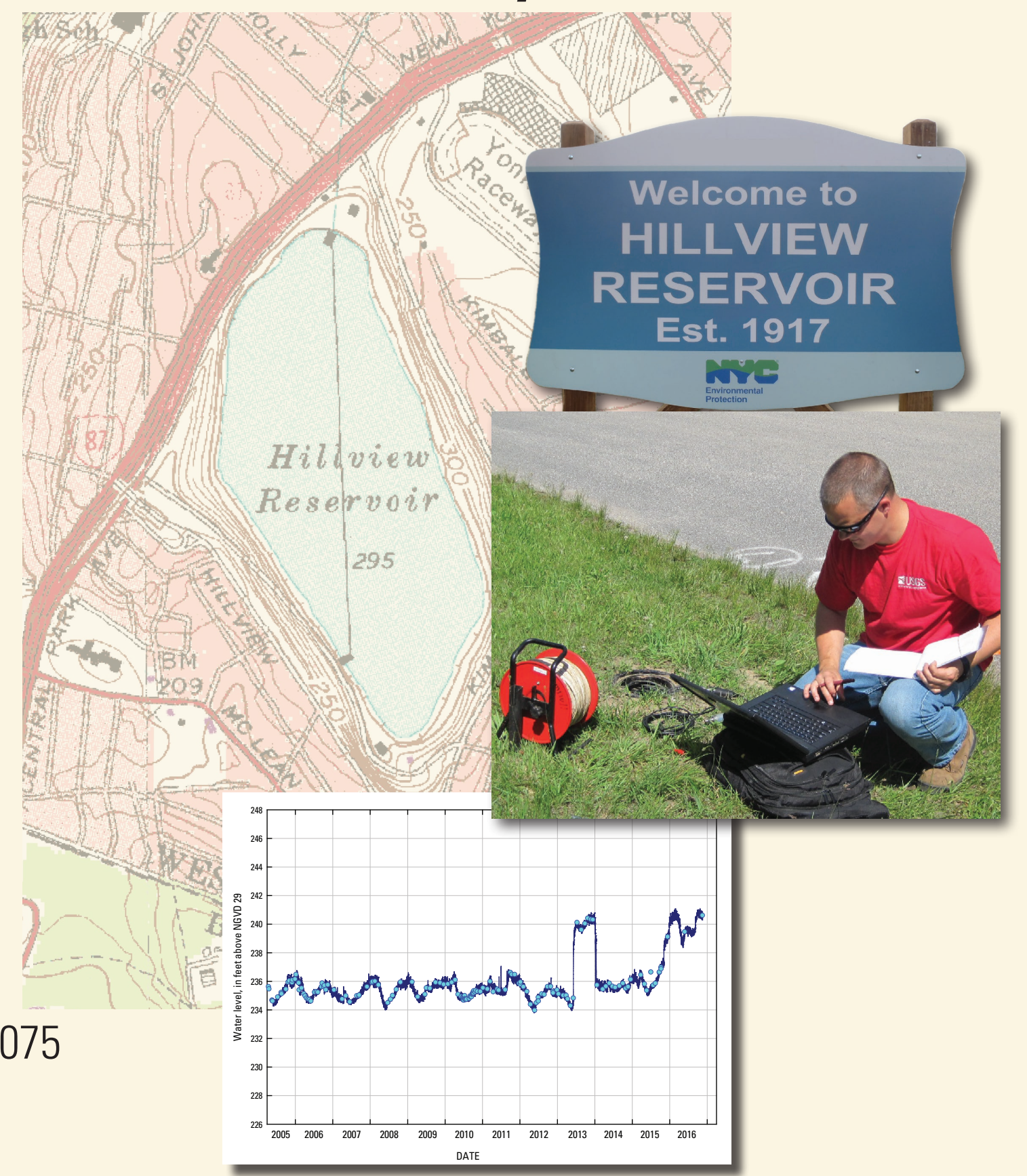

U.S. Department of the Interior

U.S. Geological Survey 
Cover (clockwise). U.S. Geological Survey (USGS) 7.5-minute (1:24,000-scale) topographic map of Mount Vernon, New York; from The National Map.

Welcome sign posted at an earthen dam site in Westchester County, New York; photograph by Michael L. Noll, USGS.

USGS scientist downloading data from a water level recorder; photograph by Simonette Rivera, USGS. Hydrograph for observation well TB-5S from an earthen dam site in Westchester County, New York, showing data from 2005 to 2016. 


\section{Groundwater-Level Data From an Earthen Dam Site in Southern Westchester County, New York}

By Michael L. Noll and Anthony Chu

Prepared in cooperation with the

New York City Department of Environmental Protection

Data Series 1075 


\title{
U.S. Department of the Interior \\ RYAN K. ZINKE, Secretary
}

\section{U.S. Geological Survey William H. Werkheiser, Deputy Director exercising the authority of the Director}

\author{
U.S. Geological Survey, Reston, Virginia: 2018
}

For more information on the USGS - the Federal source for science about the Earth, its natural and living resources, natural hazards, and the environment-visit https://www.usgs.gov or call 1-888-ASK-USGS.

For an overview of USGS information products, including maps, imagery, and publications, visit https://store.usgs.gov.

Any use of trade, firm, or product names is for descriptive purposes only and does not imply endorsement by the U.S. Government.

Although this information product, for the most part, is in the public domain, it also may contain copyrighted materials as noted in the text. Permission to reproduce copyrighted items must be secured from the copyright owner.

Suggested citation:

Noll, M.L., and Chu, A., 2018, Groundwater-level data from an earthen dam site in southern Westchester County, New York: U.S. Geological Survey Data Series 1075, 35 p., https://doi.org/10.3133/ds1075.

ISSN 2327-0271 (print) ISSN 2327-638X (online) ISBN 978-1-4113-4200-2 


\section{Acknowledgments}

The authors thank Richard Zunino, Will Melendez, and Masud Ahmed of the New York City

Department of Environmental Protection for their technical assistance and logistical support and for their cooperation in providing timely information on reservoir operations and construction to ensure successful U.S. Geological Survey field efforts. The authors also thank William Capurso, Peter Joesten, and Michael D. Como of the U.S. Geological Survey for their technical support during hydrologic data collection. 



\section{Contents}

Acknowledgments ……...................................................................................................................

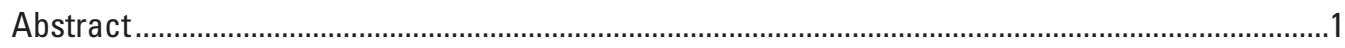

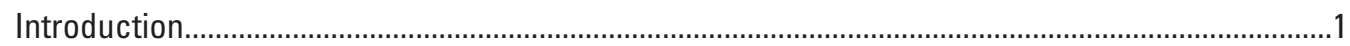

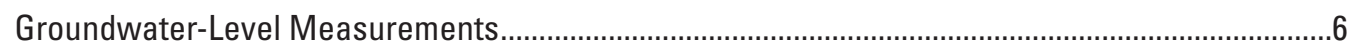

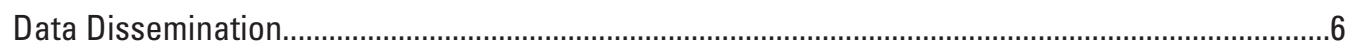

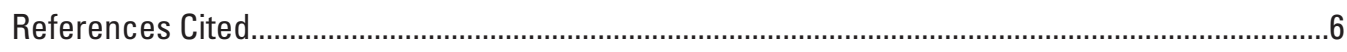

Appendix 1. Discrete and Continuous-Record Groundwater-Level Measurements for

Observation Wells in Bronx and Westchester Counties, New York .....................................35

\section{Figures}

1. Map showing location of the Hillview Reservoir study area and selected observation wells in Westchester County, New York....................................................2

2. Map showing location of observation wells on the southern embankment at the Hillview Reservoir in Westchester County, New York.

3-52. Graphs showing discrete and continuous-record groundwater-level measurements for observation wells from an earthen dam site in southern Westchester County, New York:

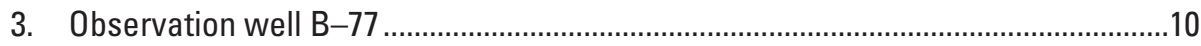

4. Observation well TB-1S .................................................................................

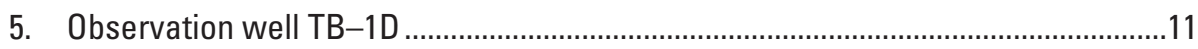

6. Observation well TB-2S .......................................................................................11

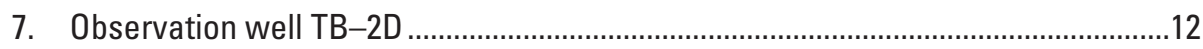

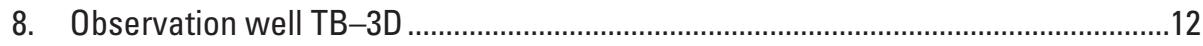

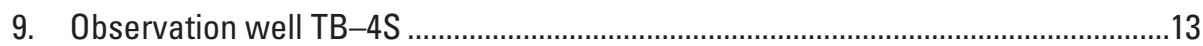

10. Observation well TB-4D ..................................................................................13

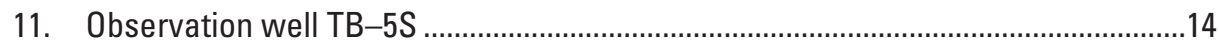

12. Observation well TB-5D .................................................................................. 14

13. Observation well TB-8

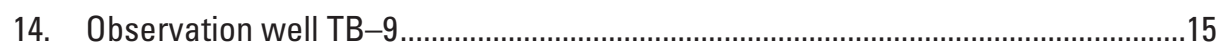

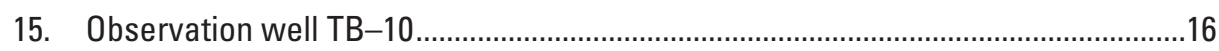

16. Observation well TB-11B ...............................................................................16

17. Observation well TB-12

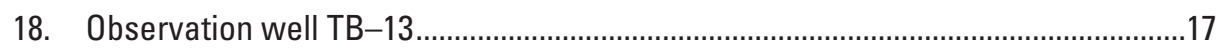

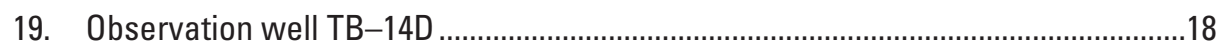

20. Observation well TB-15 ....................................................................................18

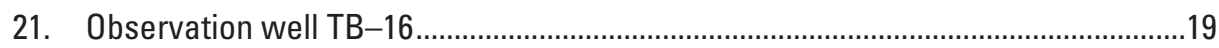

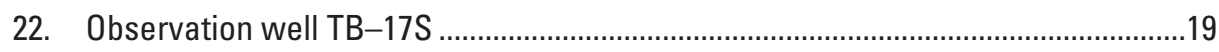

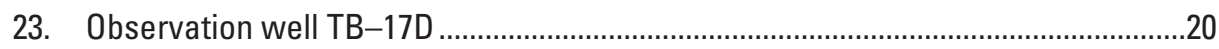

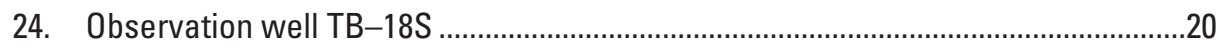

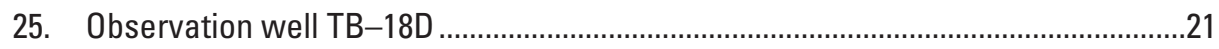

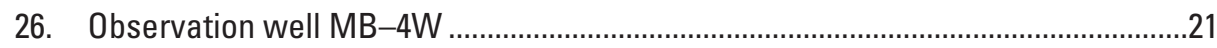

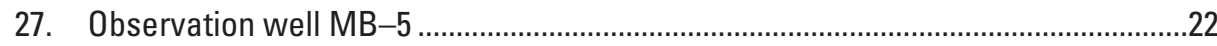




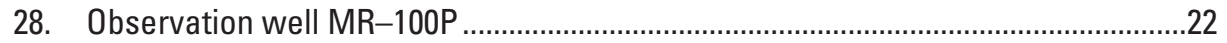

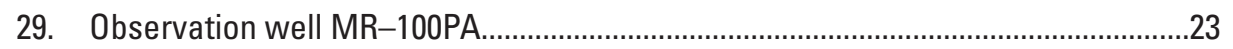

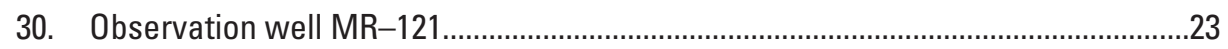

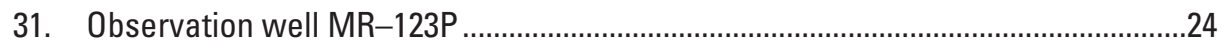

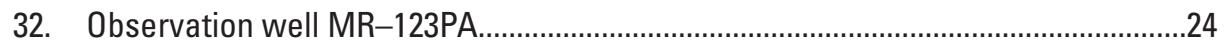

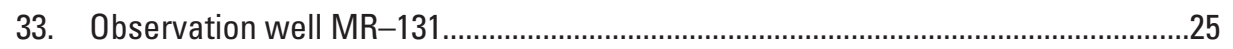

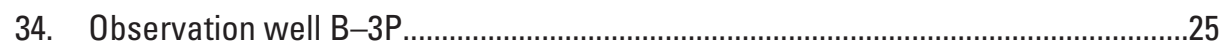

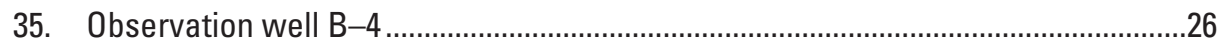

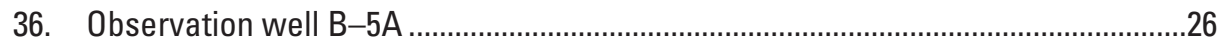

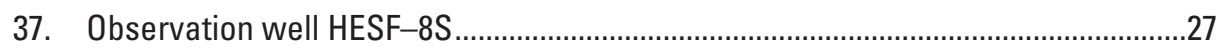

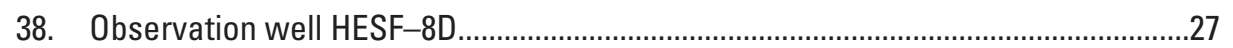

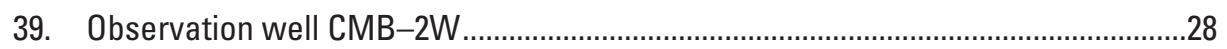

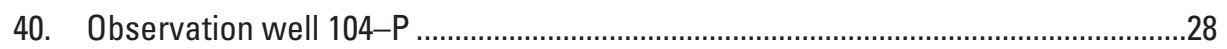

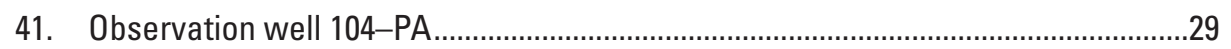

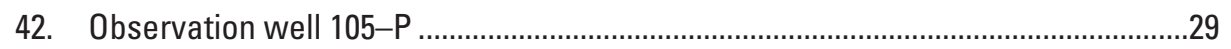

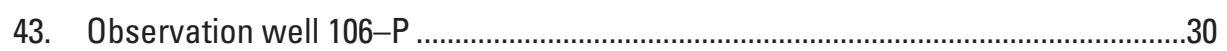

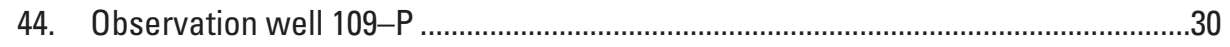

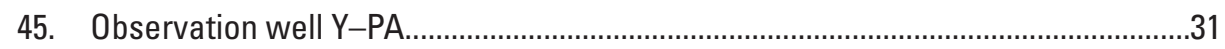

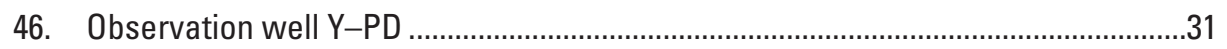

47. Observation well Z-PA..........................................................................................32

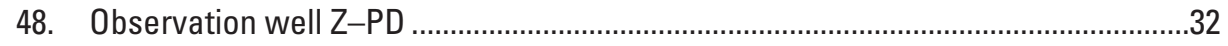

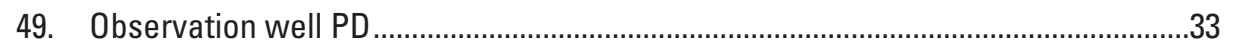

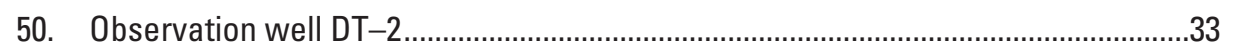

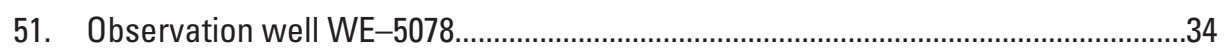

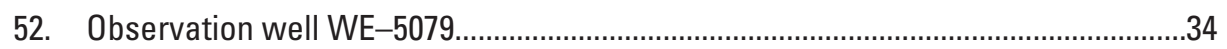

\section{Table}

1. Site information for observation wells at Hillview Reservoir in Westchester County, New York 


\section{Conversion Factors}

U.S. customary units to International System of Units

\begin{tabular}{lll}
\hline \multicolumn{1}{c}{ Multiply } & By & \multicolumn{1}{c}{ To obtain } \\
\hline inch (in.) & 2.54 & centimeter $(\mathrm{cm})$ \\
foot (ft) & 0.3048 & meter $(\mathrm{m})$ \\
mile (mi) & 1.609 & kilometer $(\mathrm{km})$ \\
acre & 0.004047 & square kilometer $\left(\mathrm{km}^{2}\right)$ \\
gallon (gal) & 3.785 & liter $(\mathrm{L})$ \\
pound, avoirdupois $(\mathrm{lb})$ & 0.4536 & kilogram $(\mathrm{kg})$ \\
pound per square inch $\left(\mathrm{lb} / \mathrm{in}^{2}\right)$ & 6.895 & kilopascal $(\mathrm{kPa})$ \\
\hline
\end{tabular}

\section{Datum}

Vertical coordinate information is referenced to the National Geodetic Vertical Datum of 1929 (NGVD 29).

Horizontal coordinate information is referenced to the North American Datum of 1983 (NAD 83).

Altitude, as used in this report, refers to distance above the vertical datum.

\section{Abbreviations}

NYCDEP New York City Department Environmental Protection

USGS U.S. Geological Survey 



\title{
Groundwater-Level Data From an Earthen Dam Site in Southern Westchester County, New York
}

\author{
By Michael L. Noll and Anthony Chu
}

\section{Abstract}

In 2005, the U.S. Geological Survey began a cooperative study with New York City Department of Environmental Protection to characterize the local groundwater-flow system and identify potential sources of seeps on the southern embankment of the Hillview Reservoir in Westchester County, New York. Groundwater levels were collected at 49 wells at Hillview Reservoir, and 1 well in northern Bronx County, from April 2005 through November 2016. Groundwater levels were measured discretely with a chalked steel or electric tape, or continuously with a digital pressure transducer, or both, in accordance with U.S. Geological Survey groundwatermeasurement standards. These groundwater-level data were plotted as time series and are presented in this report as hydrographs. Twenty-eight of the 50 hydrographs have continuous record and discrete field groundwater-level measurements, 22 of the hydrographs contain only discrete measurements.

\section{Introduction}

The Hillview Reservoir (fig. 1) in southern Westchester County, New York, which was constructed between 1913 and 1916, contains more than 900 million gallons of water and maintains a hydrostatic head of about 293 feet (ft) on the New York City water distribution system to the south. Most of the water used in New York City passes through the Hillview Reservoir facility from the Kensico Reservoir, which is fed by the Delaware and Catskill aqueducts in upstate New York. Water is chlorinated at the reservoir and is piped from the southern end of the reservoir for distribution to users in New York City. The 90 -acre reservoir, which is partly lined by concrete, is about equally divided into the East Basin and West Basin by a concrete-dividing wall. It has operated continuously since the first water tunnel was completed in 1917.

The earthen embankment comprises highly compact, low-permeability glacial clays that were excavated from the site and rest on a veneer of low-permeability glacial till that overlie crystalline bedrock (New York City Department of Environmental Protection, 1909; Malcolm Pirnie, Inc. and
TAMS Consultants, Inc., 2002). The earthen embankment was subsequently modified by other construction and maintenance projects near the downtake, uptake, and control chambers; connecting shafts; connecting conduits; the reservoir dividing wall; and the bypass tunnel that are critical to reservoir operations (fig. 2).

From April 2005 through November 2016, the U.S. Geological Survey (USGS), in cooperation with the New York City Department of Environmental Protection, collected hydraulic-head data (groundwater levels) at 49 wells at Hillview Reservoir and 1 well in northern Bronx County. The principal objectives of this study were to characterize the distribution of groundwater levels near the reservoir to better understand the embankment groundwater-flow system, characterize possible flow paths of water to the seeps, and monitor the long- and short-term changes in groundwater levels and seep discharge within the study area.

Groundwater-level data from the 50 wells that were monitored during the project are shown in hydrographs in this report (figs. 3-52) and can be retrieved from the USGS National Water Information System (U.S. Geological Survey, 2016) by using the USGS site identifiers in table 1 . These data are also available in tabular format in appendix 1.

Groundwater generally flows or seeps outward from the reservoir through the low-permeability embankment toward the surrounding glacial drift. Since 1999, several seeps downslope from the East Basin have flowed out from the western side of the southern embankment, which is the steepest slope at the Hillview Reservoir (fig. 2). One seep that flowed continuously during the study was discovered during an inspection of the embankment in 1999 (George Schmitt, New York City Department of Environmental Protection, written commun., 2007). In 2001, the New York City Department of Environmental Protection (NYCDEP) drilled 25 wells at the southern end of the reservoir, adding to the 32 wells previously installed around the reservoir in an effort to locate the potential sources of the continuous flowing seep. The NYCDEP approach included taking periodic depth-towater measurements and sampling reservoir and spring water for major ions (Malcolm Pirnie, Inc. and TAMS Consultants, Inc., 2002). 


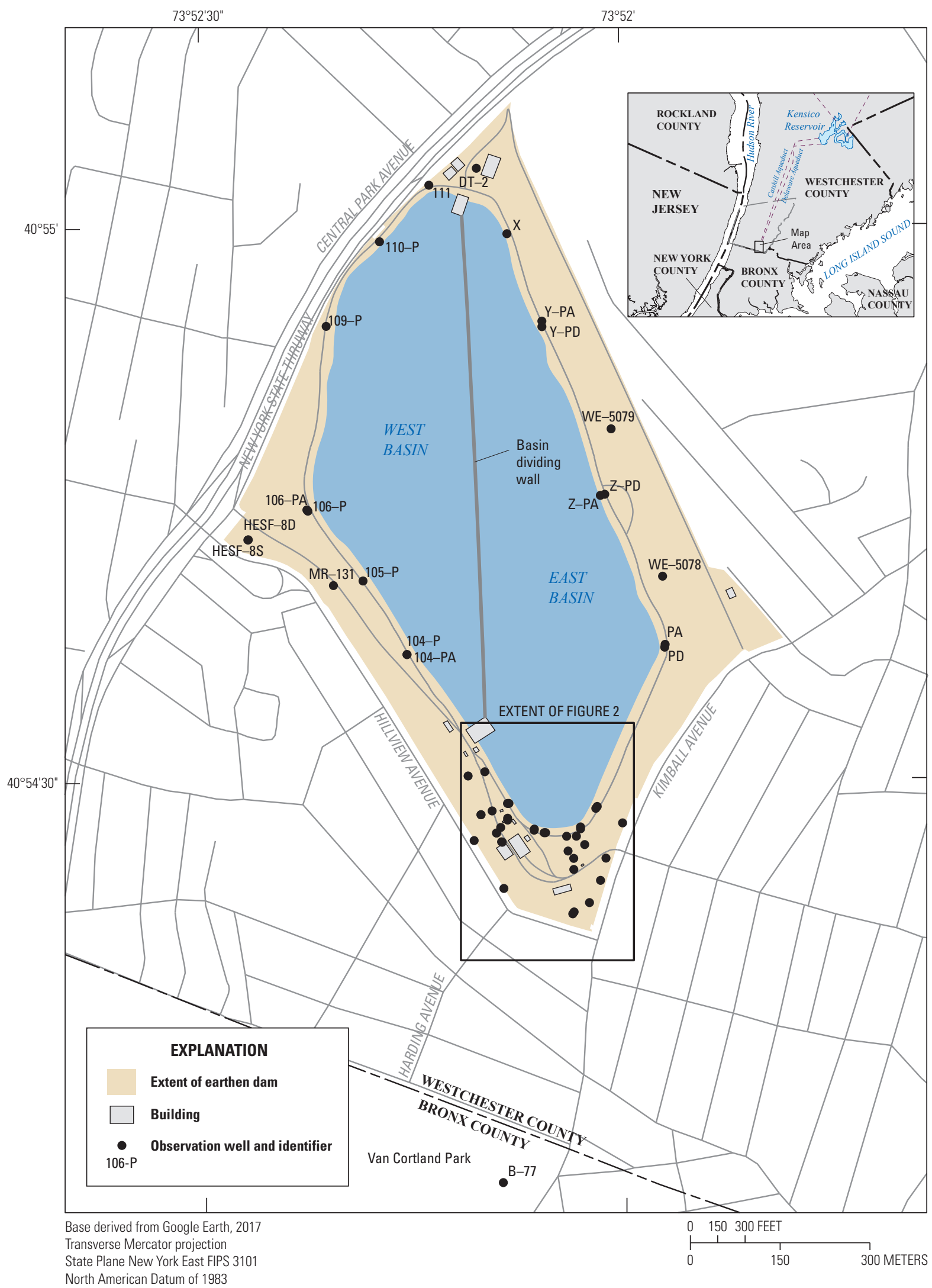

Figure 1. Location of the Hillview Reservoir study area and selected observation wells in Westchester County, New York. 


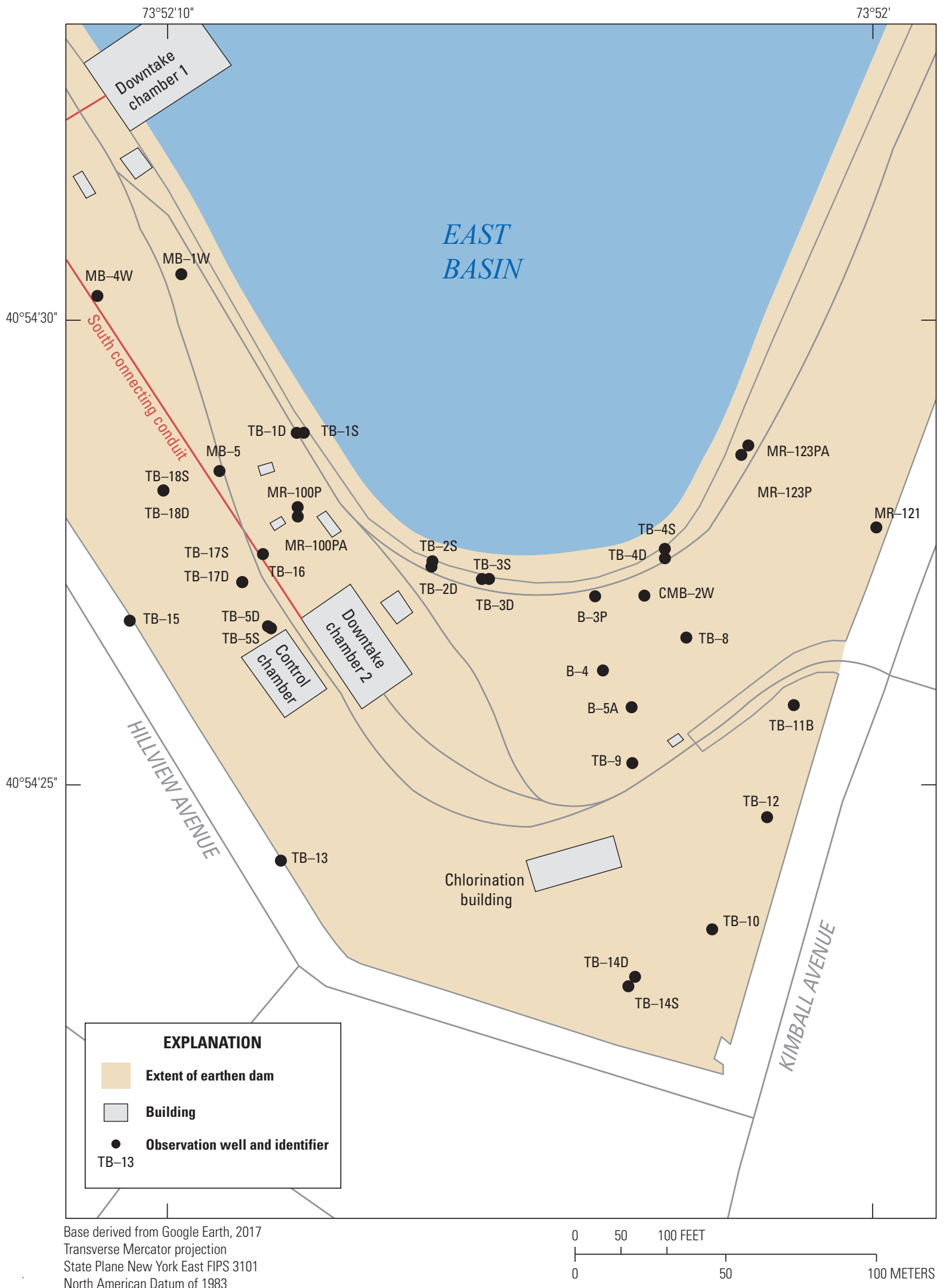

Figure 2. Location of observation wells on the southern embankment at the Hillview Reservoir in Westchester County, New York. 
Table 1. Site information for observation wells at Hillview Reservoir in Westchester County, New York.

[Altitudes are in feet above the National Geodetic Vertical Datum of 1929. Depths are in feet below land surface. Latitude and longitude are referenced to the North American Datum of 1983. NYSDEC, New York State Department of Environmental Conservation; ID, identifier; USGS, U.S. Geological Survey; ft, foot; —, no data; D, discrete measurements only; DC, discrete and continuous-record measurements]

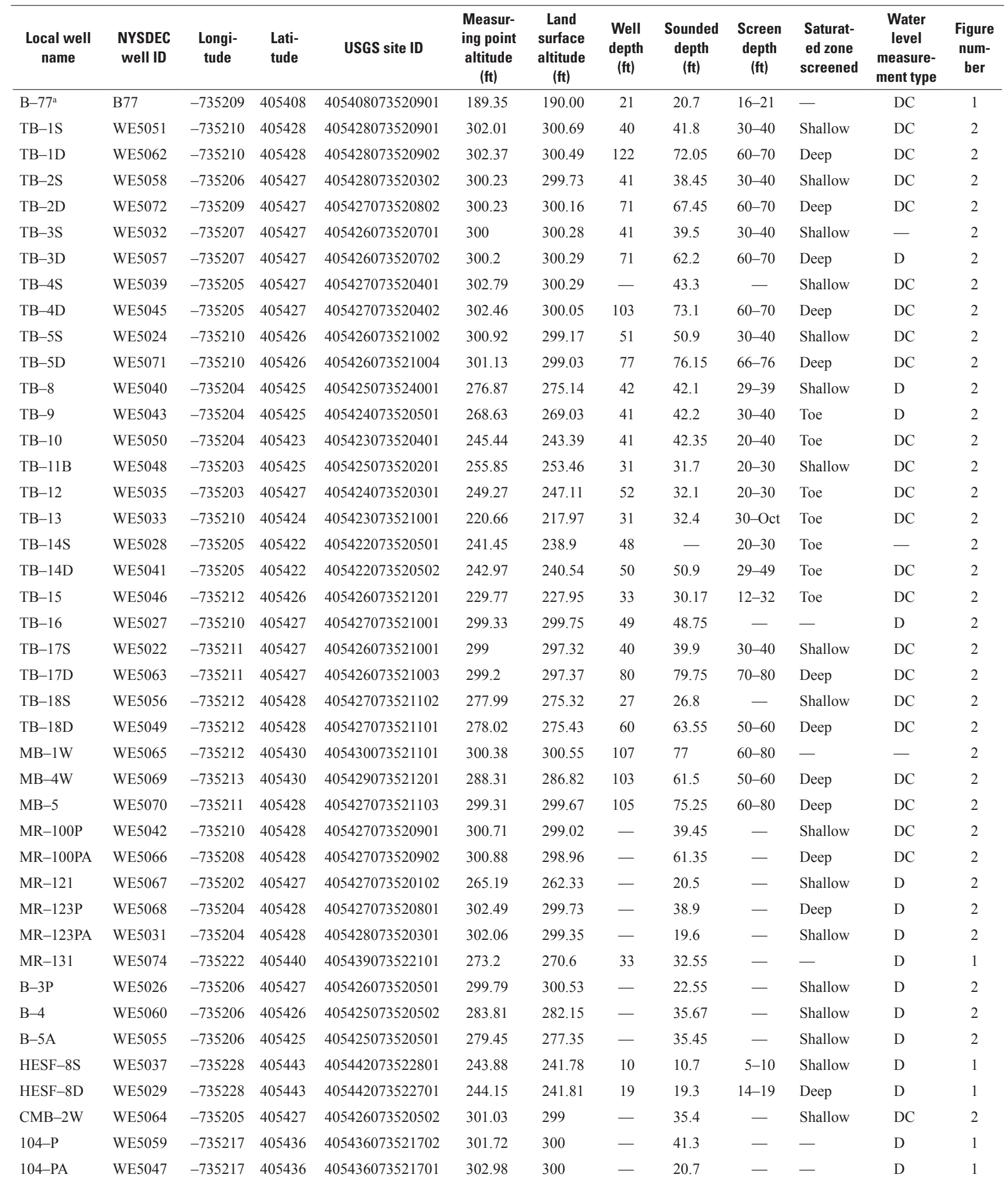


Table 1. Site information for observation wells at Hillview Reservoir in Westchester County, New York.-Continued

[Altitudes are in feet above the National Geodetic Vertical Datum of 1929. Depths are in feet below land surface. Latitude and longitude are referenced to the North American Datum of 1983. NYSDEC, New York State Department of Environmental Conservation; ID, identifier; USGS, U.S. Geological Survey; ft, foot; —, no data; D, discrete measurements only; DC, discrete and continuous-record measurements]

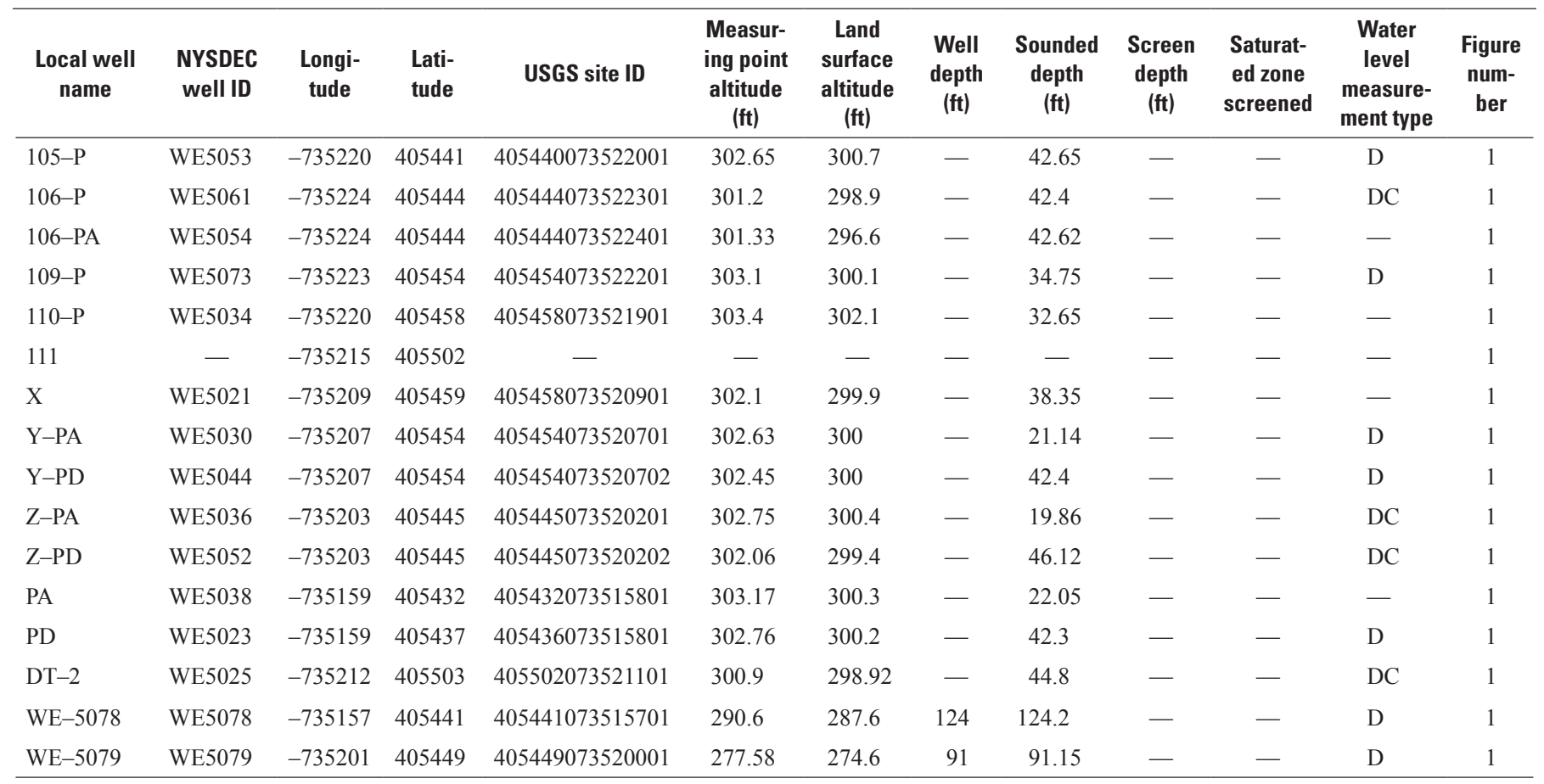

${ }^{a}$ Well B-77 is in Bronx County. 
In 2005, the U.S. Geological Survey (USGS) began a cooperative study with the NYCDEP to investigate the relevant hydrogeologic framework to characterize the local groundwater-flow system and to determine possible sources of the seeps (Chu and others, 2013). In August 2011, the USGS drilled one additional well, B-77 (fig. 1; table 1), south of the reservoir in Van Cortland Park in Bronx County to supplement the existing 57-monitoring-well network. The USGS was able to access 50 of the 58 wells for monitoring groundwater levels.

\section{Groundwater-Level Measurements}

Discrete and continuous-record groundwater levels were collected at 50 of the 58 wells from April 2005 through November 2016 (fig. 1; table 1). Groundwater-level data were not collected from eight sites (TB-3S, TB-14S, MB-1W, 106-PA, 110-P, 111, X, and PA) in the monitoring network because these wells were decommissioned, damaged, or destroyed before the beginning of the study. Groundwaterlevel records are incomplete for wells HESF-8D, HESF-8S, MR-131, Y-PA, and 104-P because they were destroyed during various construction projects at the reservoir during the study period (figs. 3 through 52, in back of report). To supplement the existing monitoring network and replace damaged or destroyed wells, MR-123P, MR-123PA, PD, and Y-PD were repaired during the study period so groundwater levels could be collected. For some wells, such as TB-16, TB-18S, and B-77, water levels occasionally dropped below the bottom of the well screen; these measurements were recorded as "dry" in the National Water Information System (NWIS) database (U.S. Geological Survey, 2016) and are not shown on the hydrographs in figures 3 through 52 (in back of report). Throughout the study, the USGS measured groundwater levels on a monthly basis except when site access was limited or denied for legal or safety concerns. Episodic groundwater measurements were made at select wells during hydraulic testing, water-quality sampling, and other data-collection activities throughout the course of the study.

Water-level measurements were either taken manually with a chalked, graduated steel tape or a calibrated electric tape from the wellhead (measuring point) or calculated from pressure-transducer output that was recorded automatically by data loggers installed on select observation wells. Manual depth-to-water measurements were made in accordance with standard USGS procedures (Cunningham and Schalk, 2011). Depth-to-water measurements were converted to groundwaterlevel altitude values by subtracting the depth-to-water measurement from the wellhead altitude. Depth-to-water measurements using the steel tape or calibrated electric tape method are considered accurate to about $0.01 \mathrm{ft}$ (Cunningham and Schalk, 2011).

Vented submersible pressure transducers were installed in 28 wells and were programmed to measure and record groundwater levels every 60 minutes. Data logged on these instruments were downloaded and corrected for instrument drift based on manual measurements of groundwater-level altitudes that were made from the wellhead measuring points during periodic field inspections from April 2005 through November 2016. The accuracy of a pressure transducer rated to 15 pounds per square inch $\left(\mathrm{lb} / \mathrm{in}^{2}\right)$ is approximately $0.05 \mathrm{ft}$ (In-Situ Inc., 2015). Hydrographs were created from the continuous-record data (figs. 3 through 52, in back of report). Discrete field measurements are included in the hydrographs to verify the continuous-record measurements, and to provide data where continuous measurements are missing throughout the period of record. Twenty-eight of the 50 hydrographs in this report have both continuous record and discrete field groundwater-level measurements; the other 22 hydrographs contain only discrete measurements.

\section{Data Dissemination}

Discrete and continuous record groundwater-level data collected during this project are shown in hydrographs in the back of this report (figs. 3-52) and can be downloaded from the USGS National Water Information System (U.S. Geological Survey, 2016). These data have been replicated from the USGS National Water Information System in appendix 1 and can be downloaded in tabular format at https://doi.org/10.3133/ds1075.

\section{References Cited}

Chu, Anthony, Stumm, Frederick, Joesten, P.K., and Noll, M.L., 2013, Geophysical and hydrologic analysis of an earthen dam site in southern Westchester County, New York: U.S. Geological Survey Scientific Investigations Report 2012-5247, 64 p. [Also available at http://pubs.usgs.gov/sir/2012/5247/.]

Cunningham, W.L., and Schalk, C.W., comps., 2011, Groundwater technical procedures of the U.S. Geological Survey: U.S. Geological Survey Techniques and Methods, book 1, chap. A1, 151 p. [Also available at https://pubs.usgs.gov/ tm/1a1/.]

In-Situ Inc., 2015, Level Troll 500: In-Situ Inc. website, accessed June 16, 2015, at https://in-situ.com/products/ level-temp-data-loggers/level-troll-500-data-logger/.

Malcolm Pirnie, Inc., and TAMS Consultants, Inc., 2002, Capital project W-10, Hillview reservoir-Cover, phase I, dividing wall stability buttress construction; south embankment monitoring and leakage investigations: U.S. Environmental Protection Agency, 18 p. 
New York City Department of Environmental Protection, 1909, Board of Water Supply, Hillview Reservoir, contract 30, May 15, 1909: New York City Department of Environmental Protection report, [unpaginated].

U.S. Geological Survey, 2016, Groundwater levels for the nation, in USGS water data for the nation: U.S. Geological Survey National Water Information System database, accessed March 23, 2017, at https://doi.org/10.5066/

F7P55KJN. [Groundwater level data directly accessible at https://waterdata.usgs.gov/nwis/gw.] 

Figures 3-52 


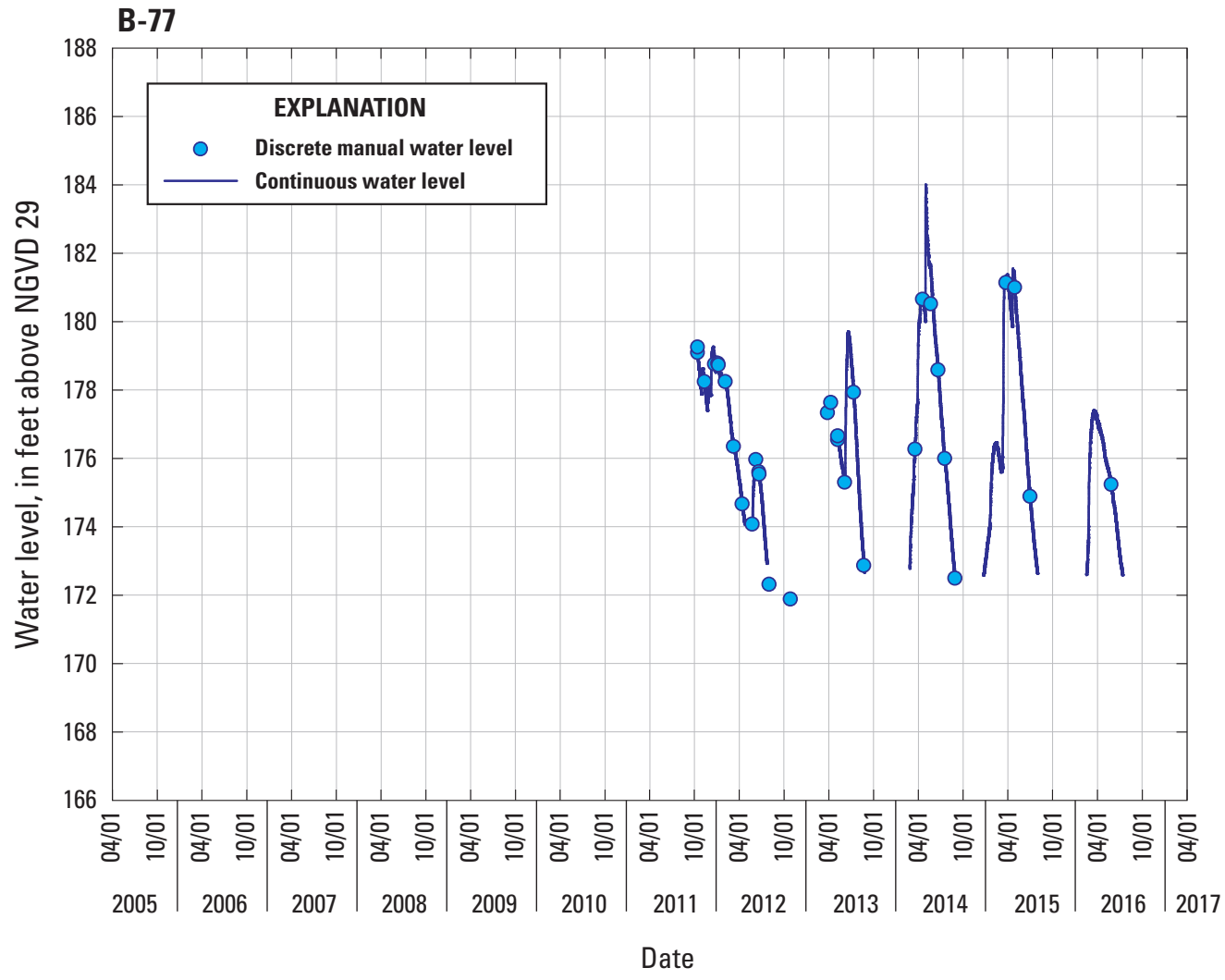

Figure 3. Discrete and continuous-record groundwaterlevel measurements for observation well B-77 from an earthen dam site in southern Westchester County, New York. Well B-77 is in Bronx County. Gaps in groundwater-level record indicate no data or a dry measurement. Location of well shown on figure 1; details are listed in table 1

\section{TB-1S}

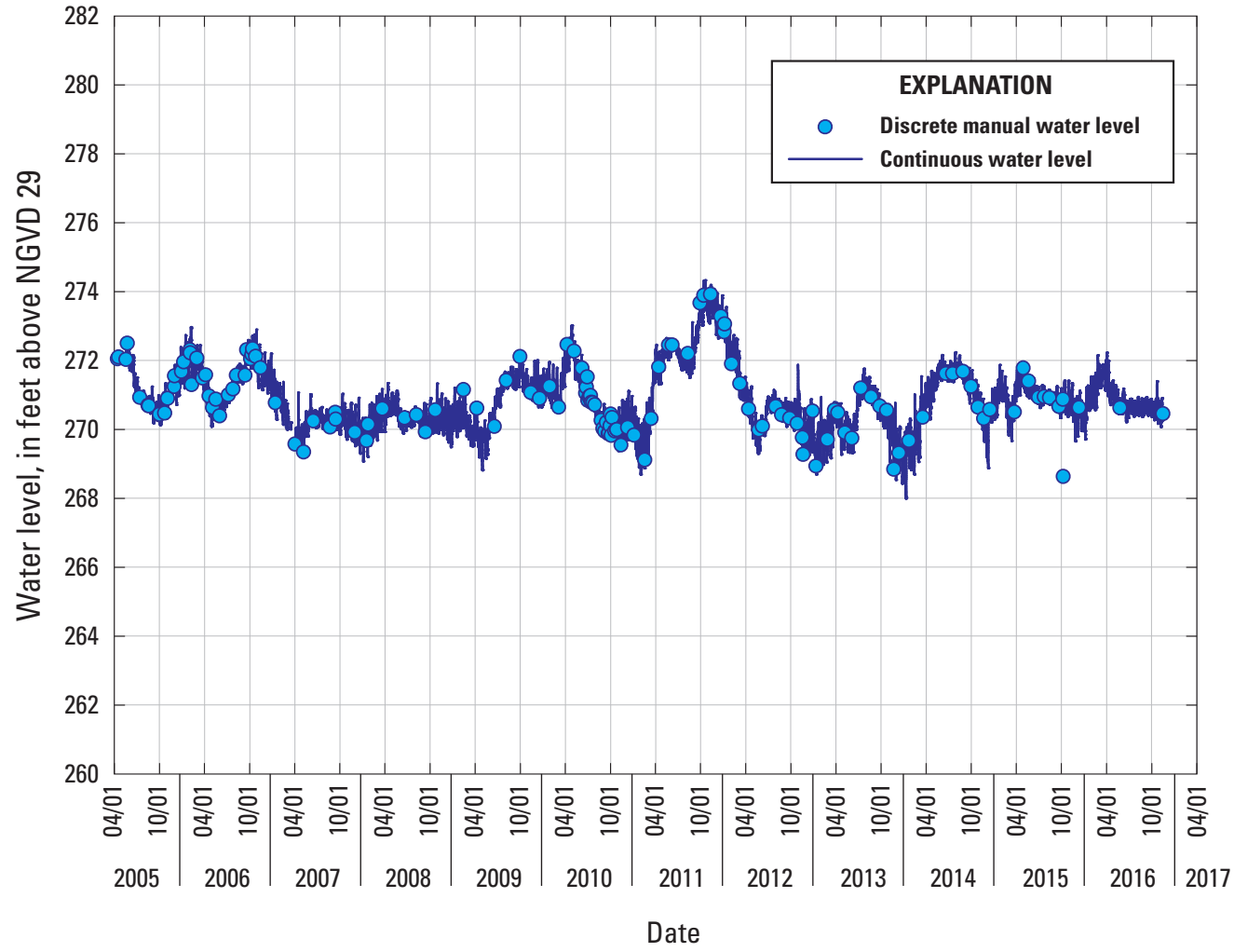

Figure 4. Discrete and continuous-record groundwaterlevel measurements for observation well TB-1S from an earthen dam site in southern Westchester County, New York. Gaps in groundwater-level record indicate no data or a dry measurement. Location of well shown on figure 2; details are listed in table 1. 
TB-1D

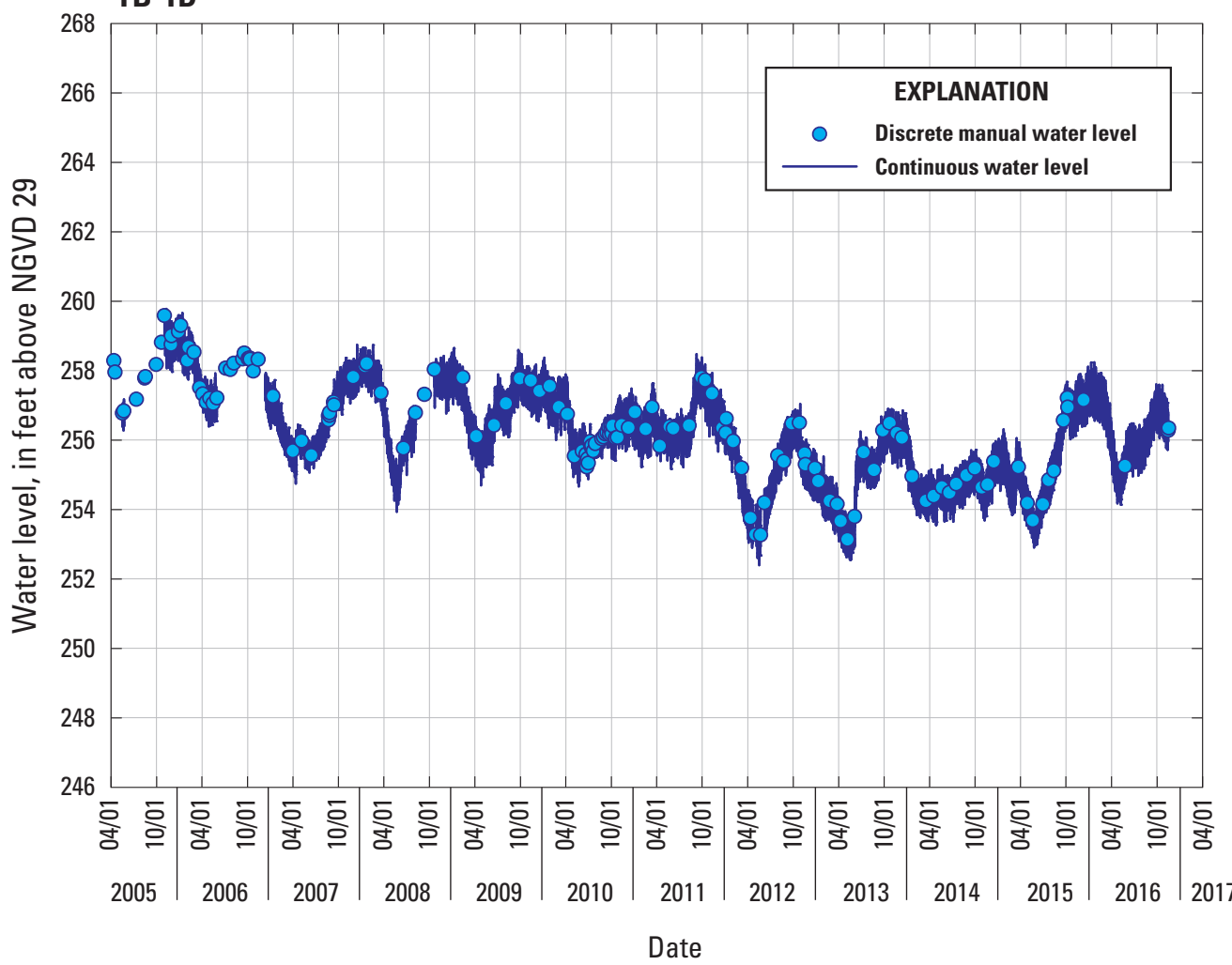

Figure 5. Discrete and continuous-record groundwaterlevel measurements for observation well TB-1D from an earthen dam site in southern Westchester County, New York. Gaps in groundwater-level record indicate no data or a dry measurement. Location of well shown on figure 2; details are listed in table 1.

\section{TB-2S}

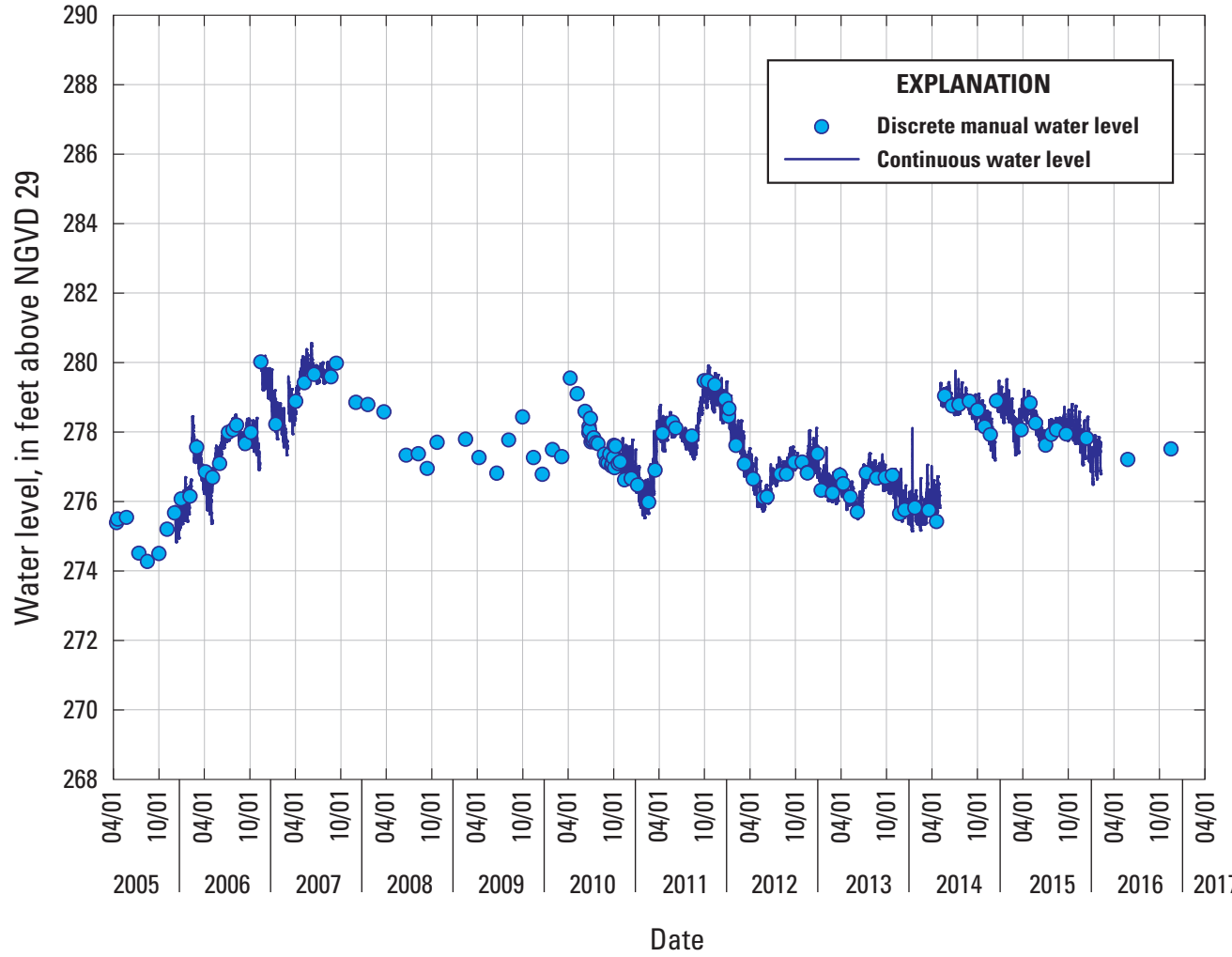

Figure 6. Discrete and continuous-record groundwaterlevel measurements for observation well TB-2S from an earthen dam site in southern Westchester County, New York. Gaps in groundwater-level record indicate no data or a dry measurement. Location of well shown on figure 2; details are listed in table 1. 
TB-2D

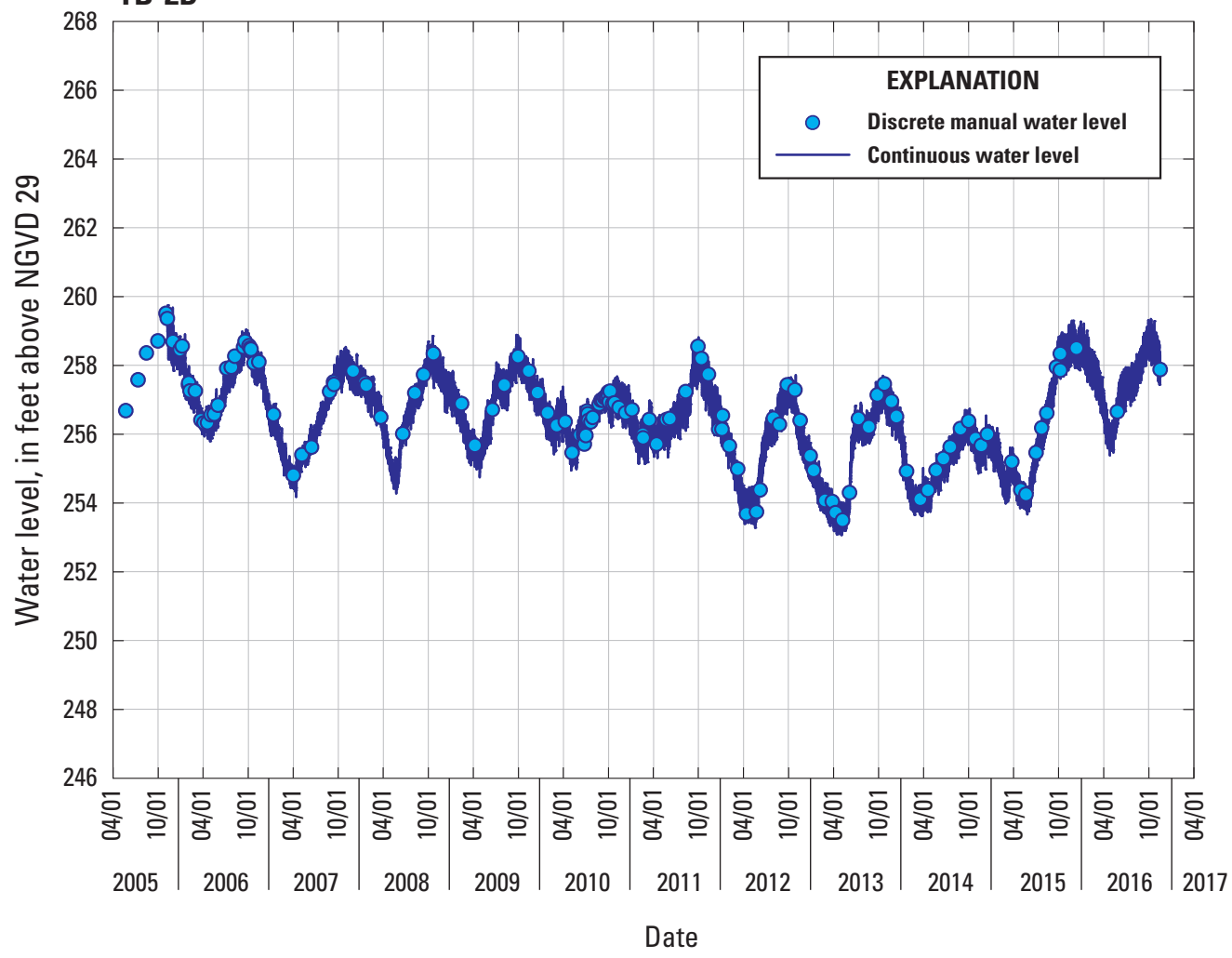

Figure 7. Discrete and continuous-record groundwaterlevel measurements for observation well TB-2D from an earthen dam site in southern Westchester County, New York. Gaps in groundwater-level record indicate no data or a dry measurement. Location of well shown on figure 2; details are listed in table 1.
TB-3D

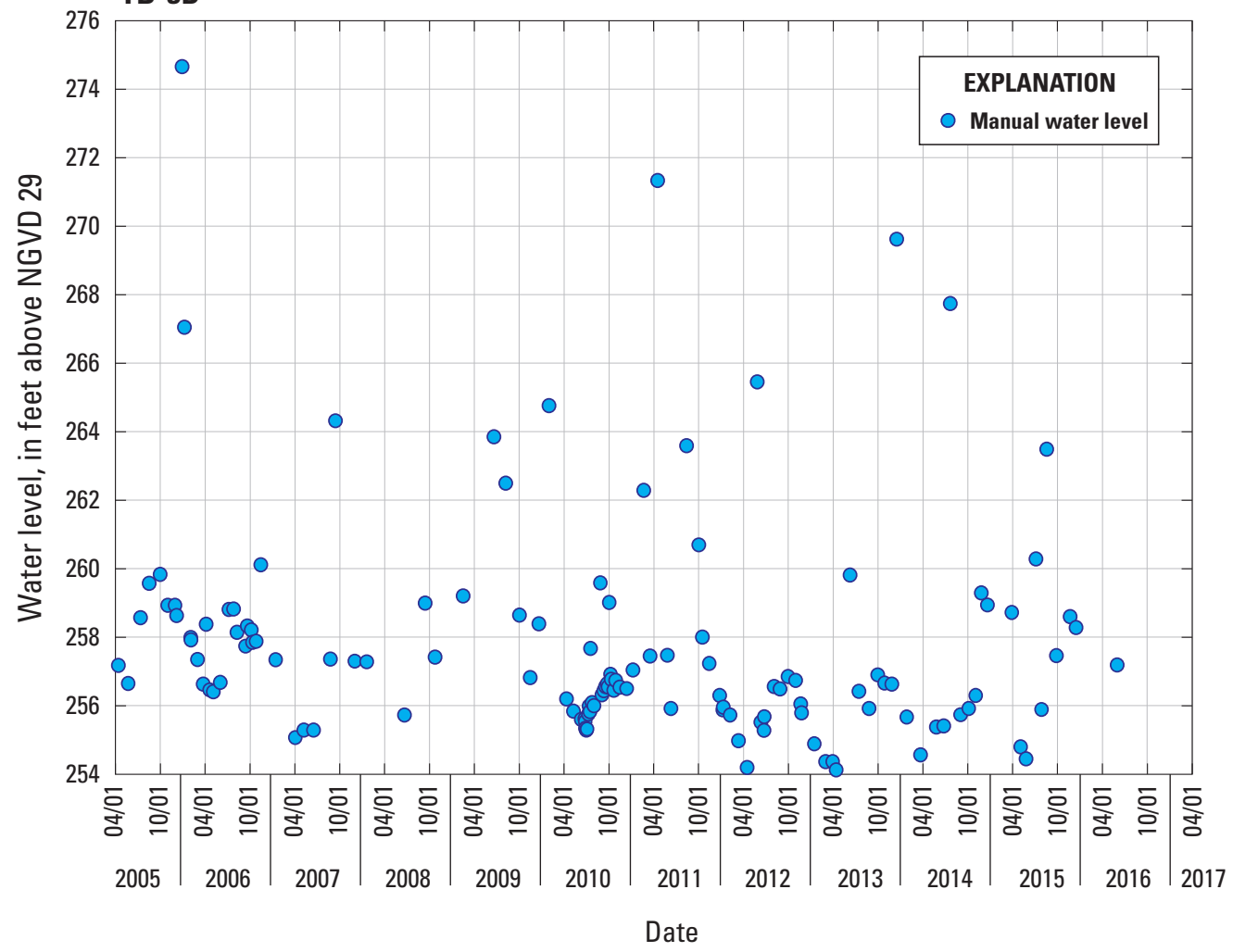

Figure 8. Discrete groundwater-level measurements for observation well TB-3D from an earthen dam site in southern Westchester County, New York. Gaps in groundwater-level record indicate no data or a dry measurement. Location of well shown on figure 2; details are listed in table 1. 
TB-4S

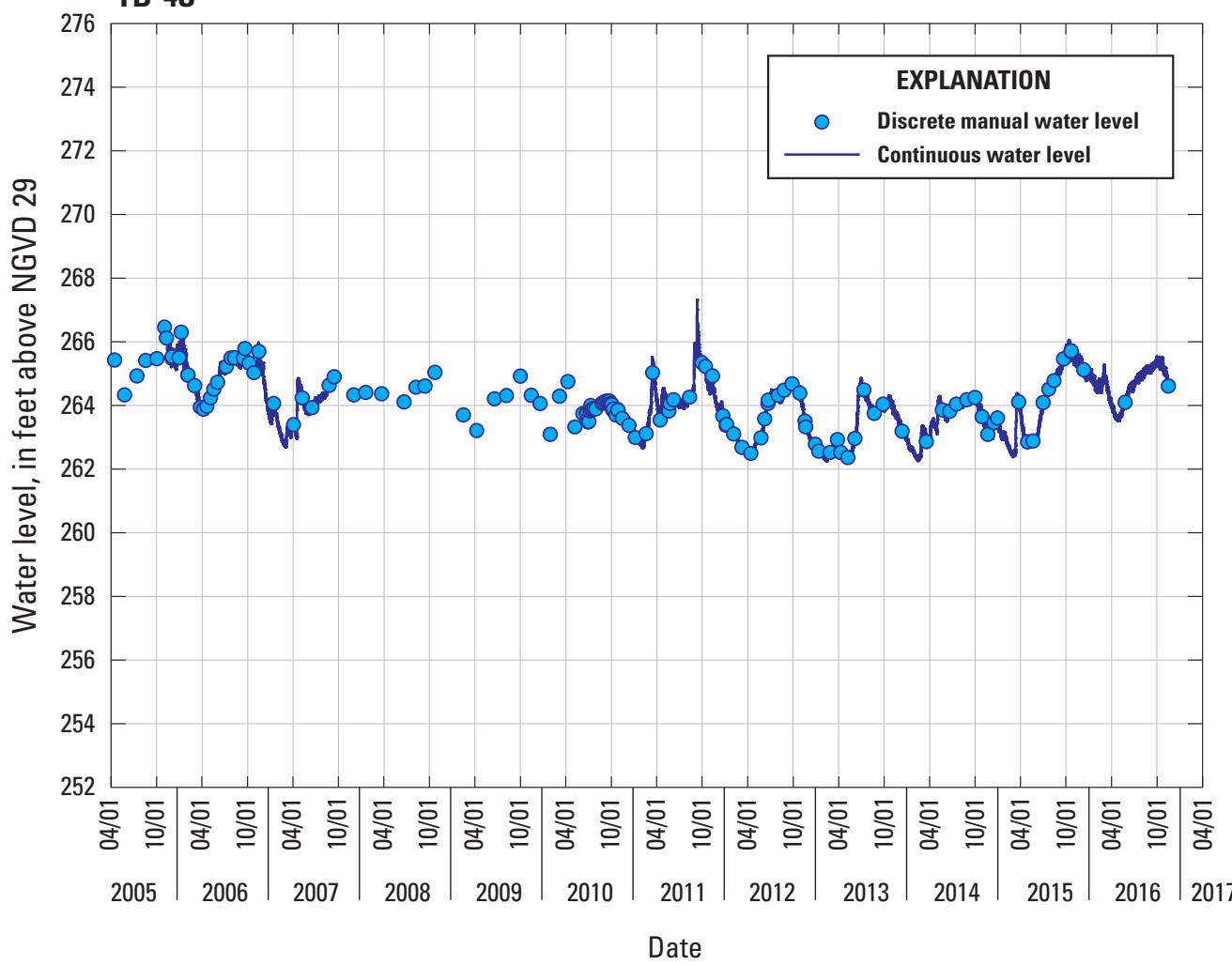

Figure 9. Discrete and continuous-record groundwaterlevel measurements for observation well TB-4S from an earthen dam site in southern Westchester County, New York. Gaps in groundwater-level record indicate no data or a dry measurement. Location of well shown on figure 2; details are listed in table 1.

\section{TB-4D}

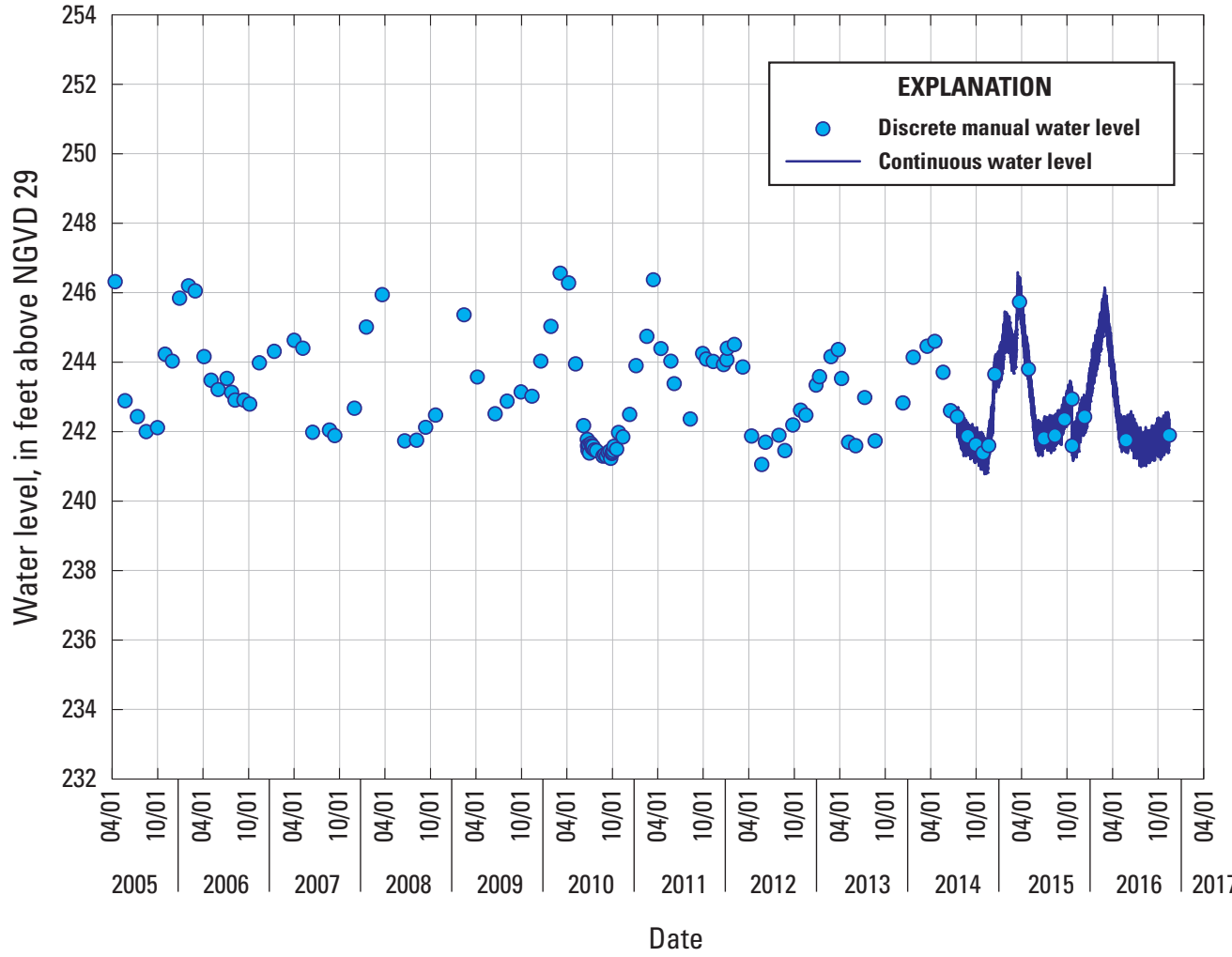

Figure 10. Discrete and continuous-record groundwaterlevel measurements for observation well TB-4D from an earthen dam site in southern Westchester County, New York. Gaps in groundwater-level record indicate no data or a dry measurement. Location of well shown on figure 2; details are listed in table 1. 
TB-5S

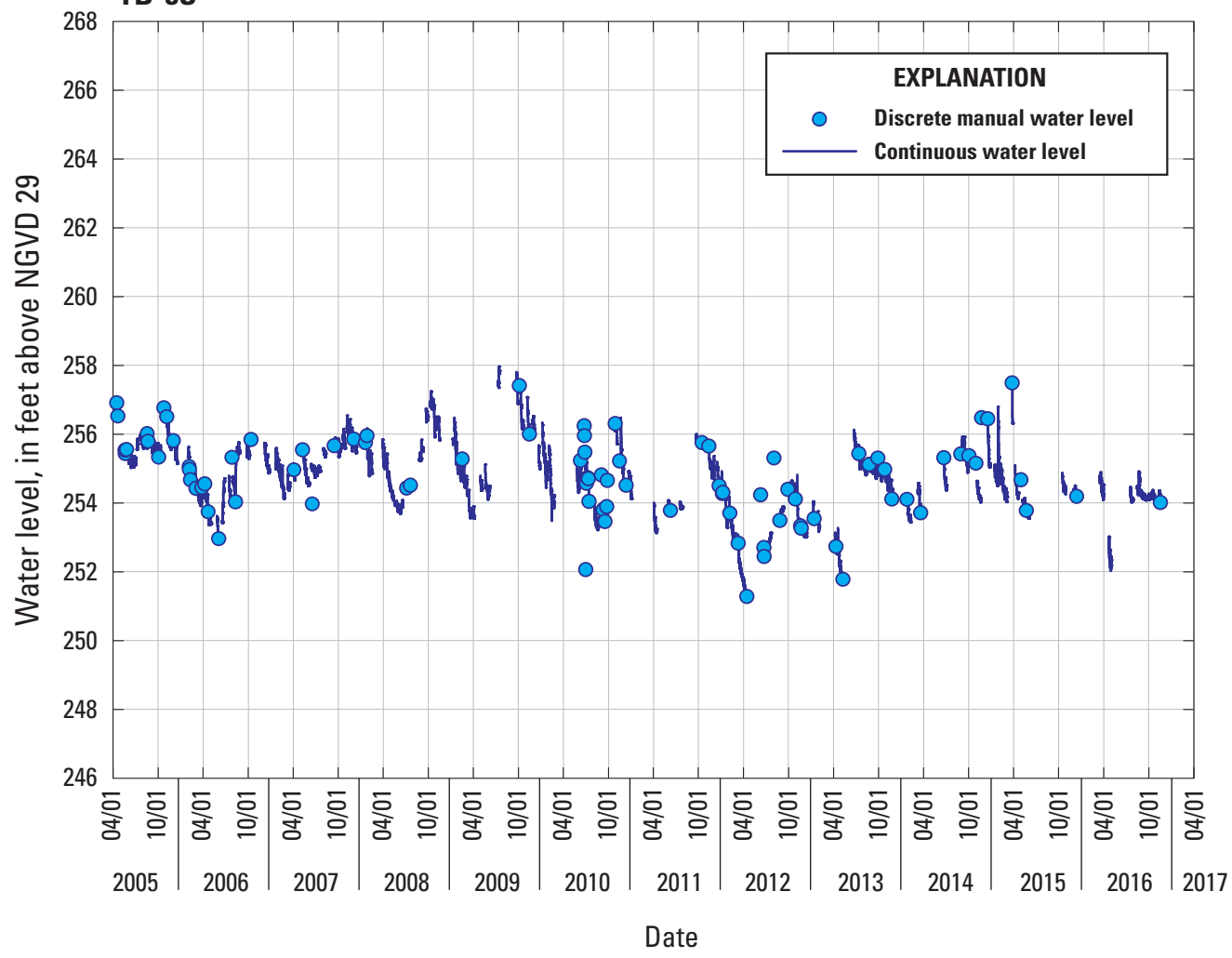

Figure 11. Discrete and continuous-record groundwaterlevel measurements for observation well TB-5S from an earthen dam site in southern Westchester County, New York. Gaps in groundwater-level record indicate no data or a dry measurement. Location of well shown on figure 2; details are listed in table 1.
TB-5D

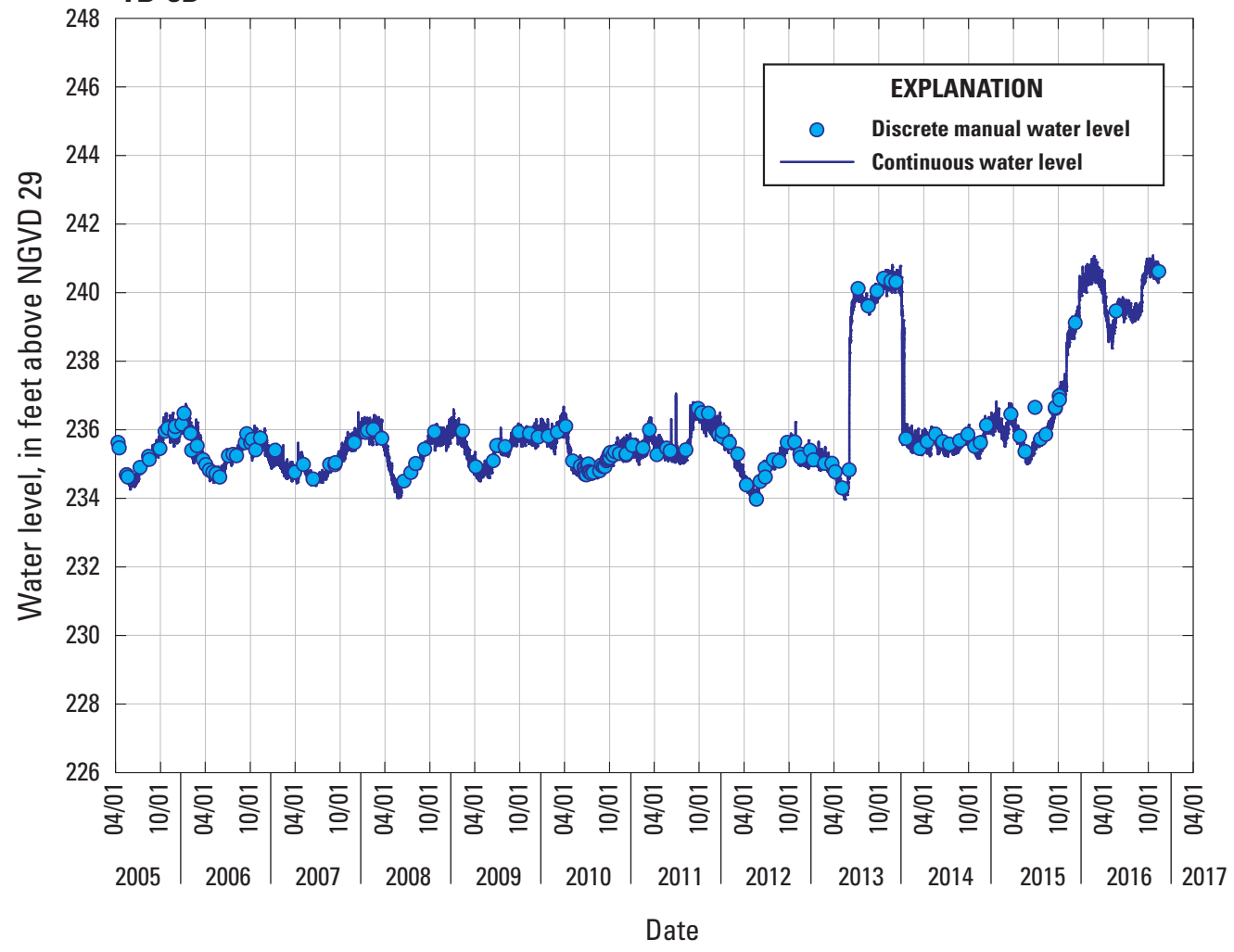

Figure 12. Discrete and continuous-record groundwaterlevel measurements for observation well TB-5D from an earthen dam site in southern Westchester County, New York. Gaps in groundwater-level record indicate no data or a dry measurement. Location of well shown on figure 2; details are listed in table 1. 
TB-8

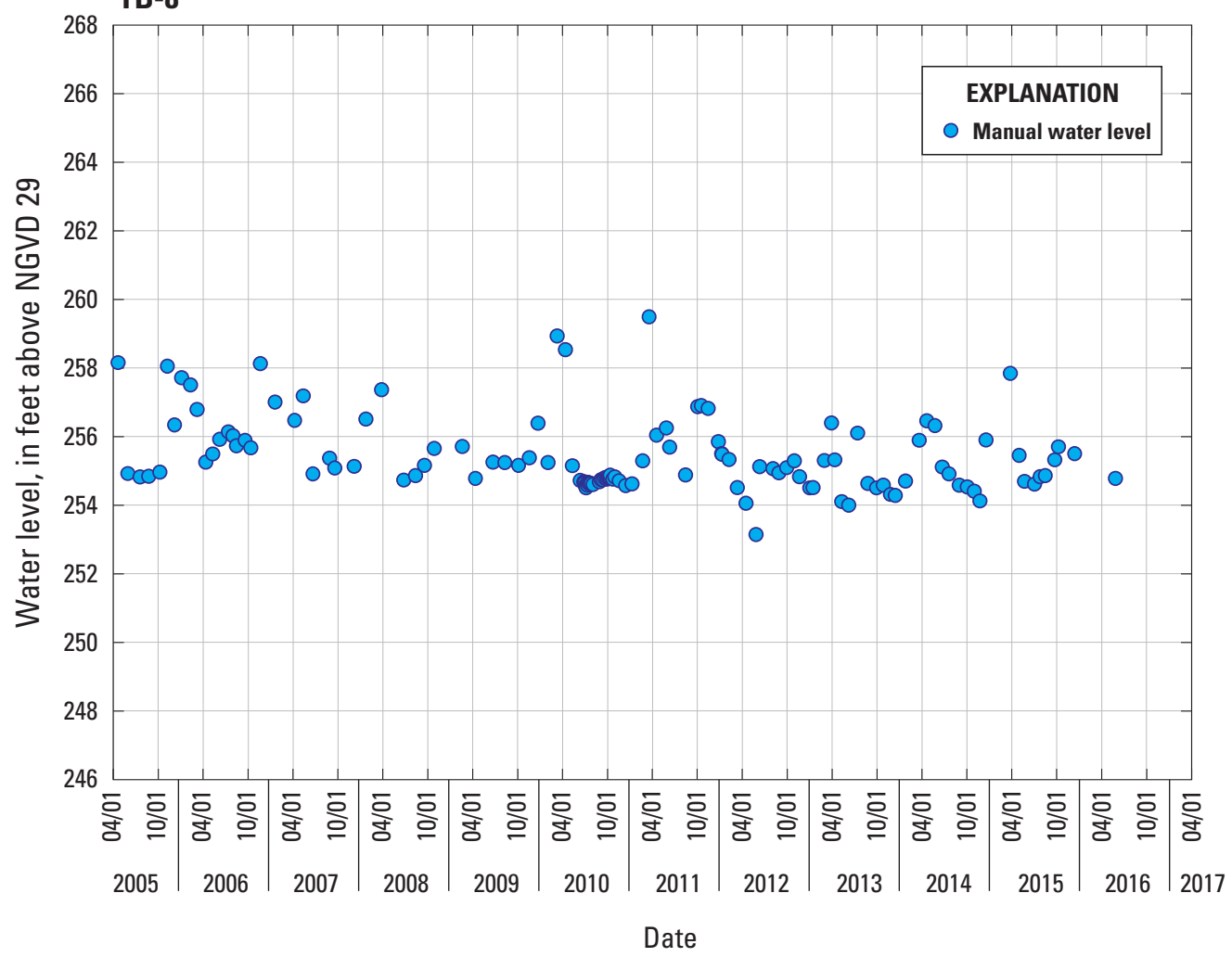

Figure 13. Discrete groundwater-level measurements for observation well TB-8 from an earthen dam site in southern Westchester County, New York. Gaps in groundwater-level record indicate no data or a dry measurement. Location of well shown on figure 2; details are listed in table 1.
TB-9

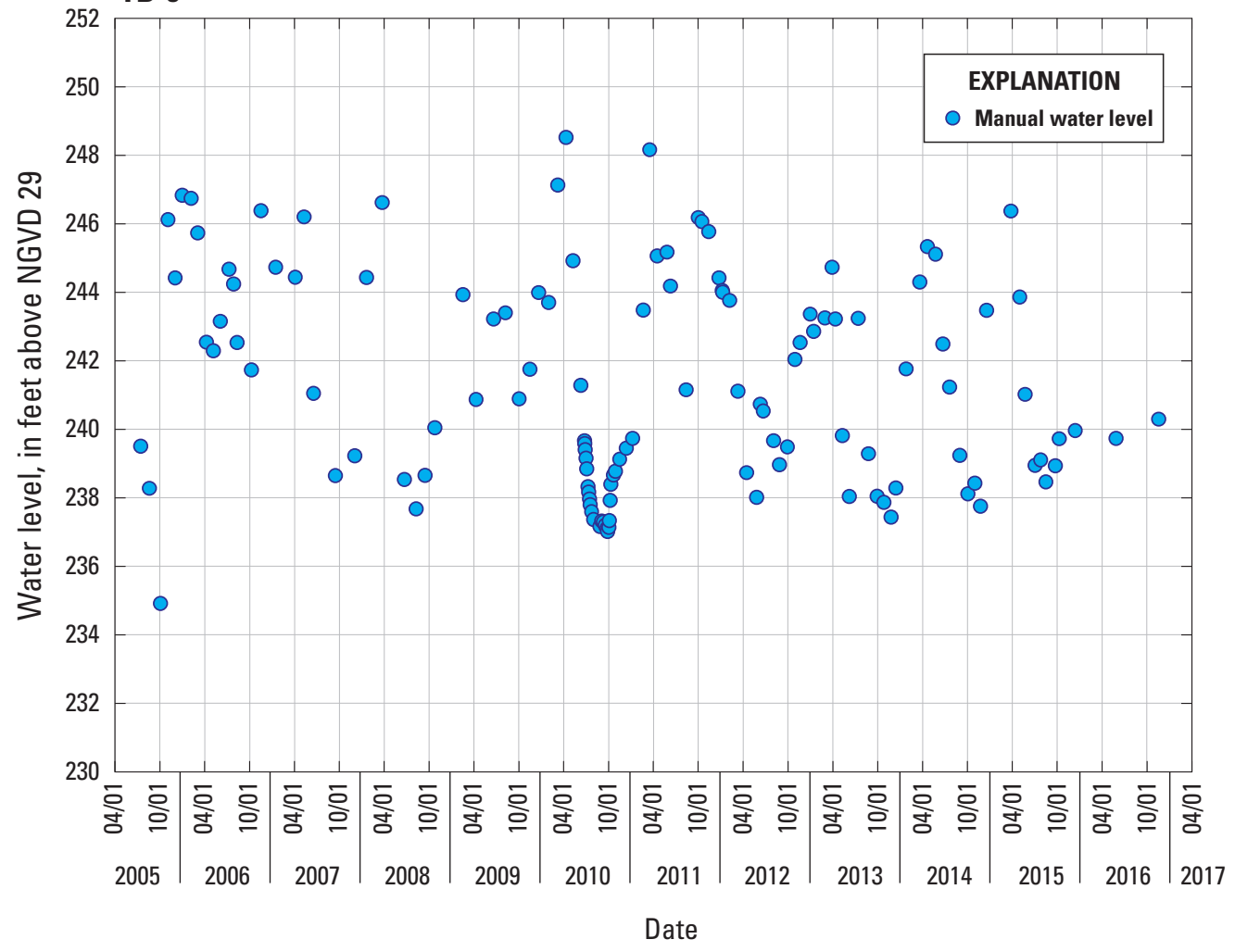

Figure 14. Discrete groundwater-level measurements for observation well TB-9 from an earthen dam site in southern Westchester County, New York. Gaps in groundwater-level record indicate no data or a dry measurement. Location of well shown on figure 2; details are listed in table 1. 
TB-10

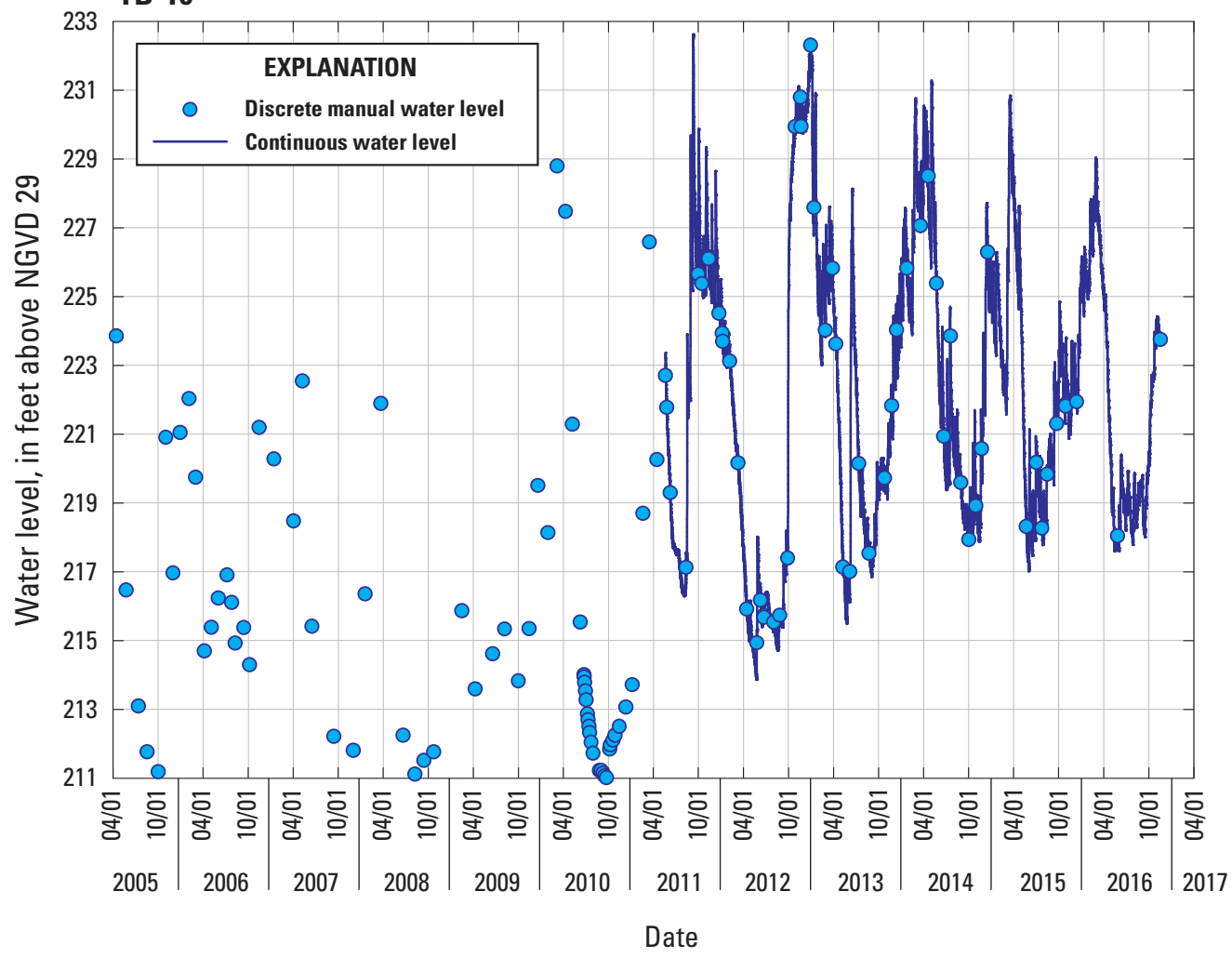

Figure 15. Discrete and continuous-record groundwaterlevel measurements for observation well TB-10 from an earthen dam site in southern Westchester County, New York. Gaps in groundwater-level record indicate no data or a dry measurement. Location of well shown on figure 2; details are listed in table 1.

\section{TB-11B}

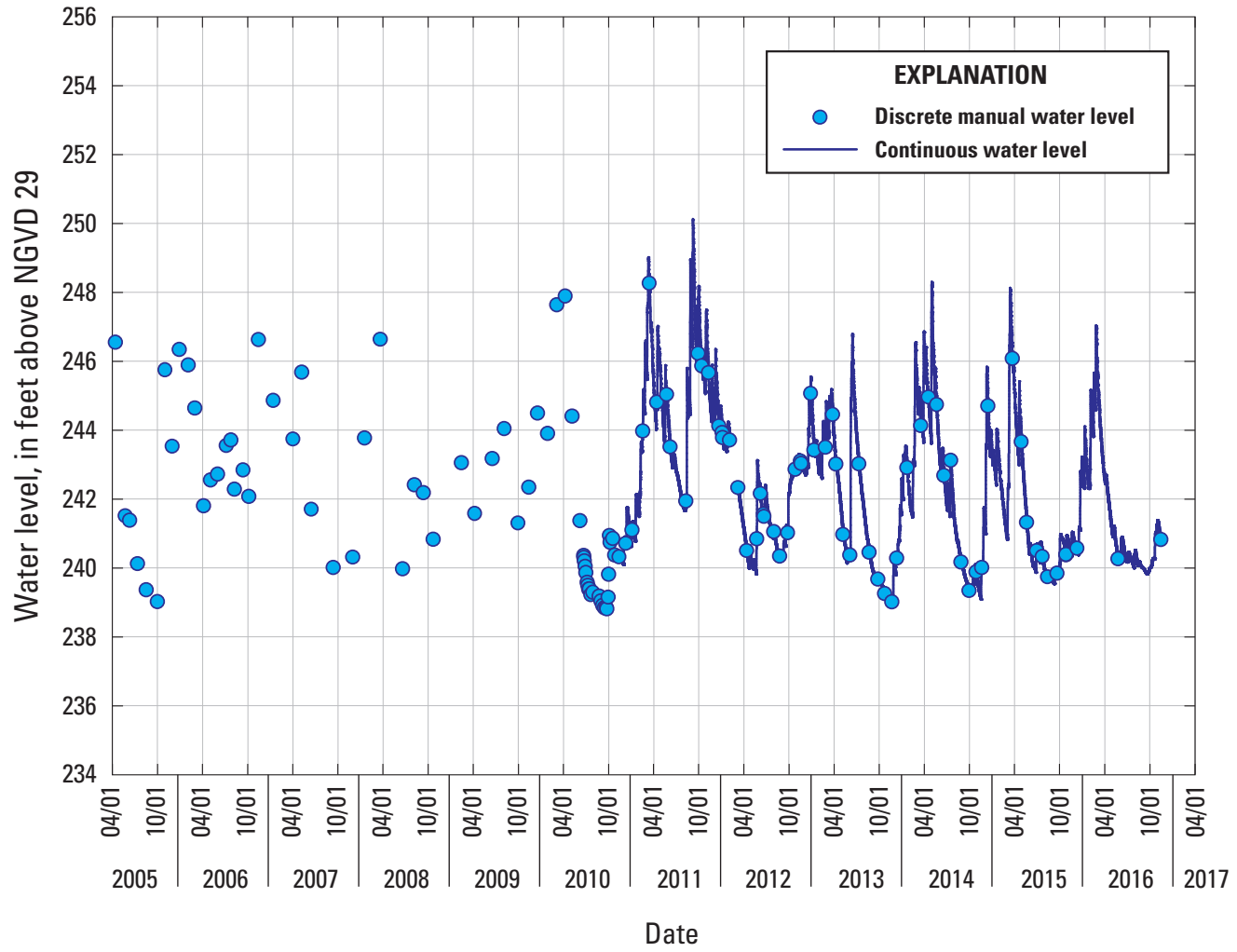

Figure 16. Discrete and continuous-record groundwaterlevel measurements for observation well TB-11B from an earthen dam site in southern Westchester County, New York. Gaps in groundwater-level record indicate no data or a dry measurement. Location of well shown on figure 2; details are listed in table 1. 
TB-12

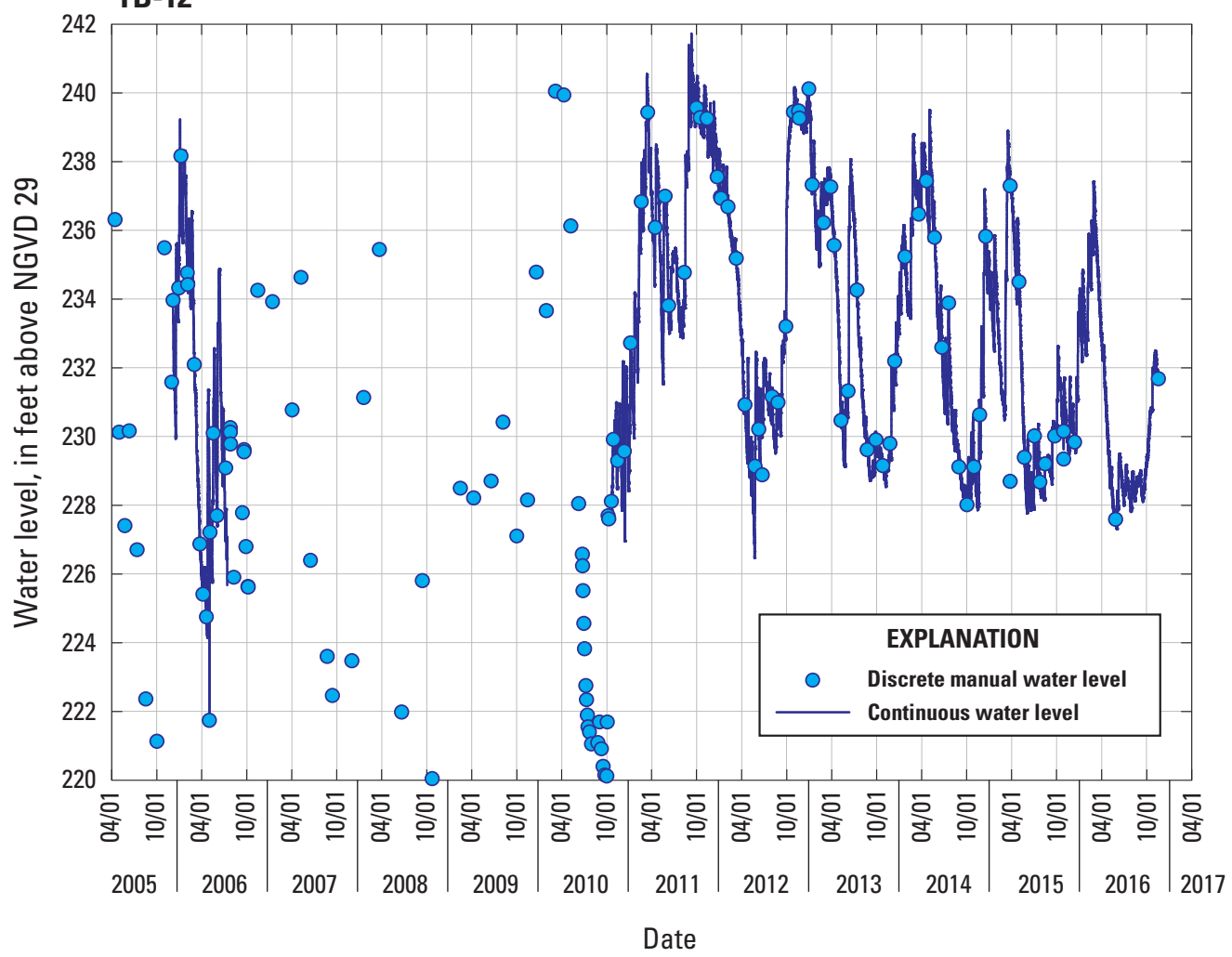

Figure 17. Discrete and continuous-record groundwaterlevel measurements for observation well TB-12 from an earthen dam site in southern Westchester County, New York. Gaps in groundwater-level record indicate no data or a dry measurement. Location of well shown on figure 2; details are listed in table 1.
TB-13

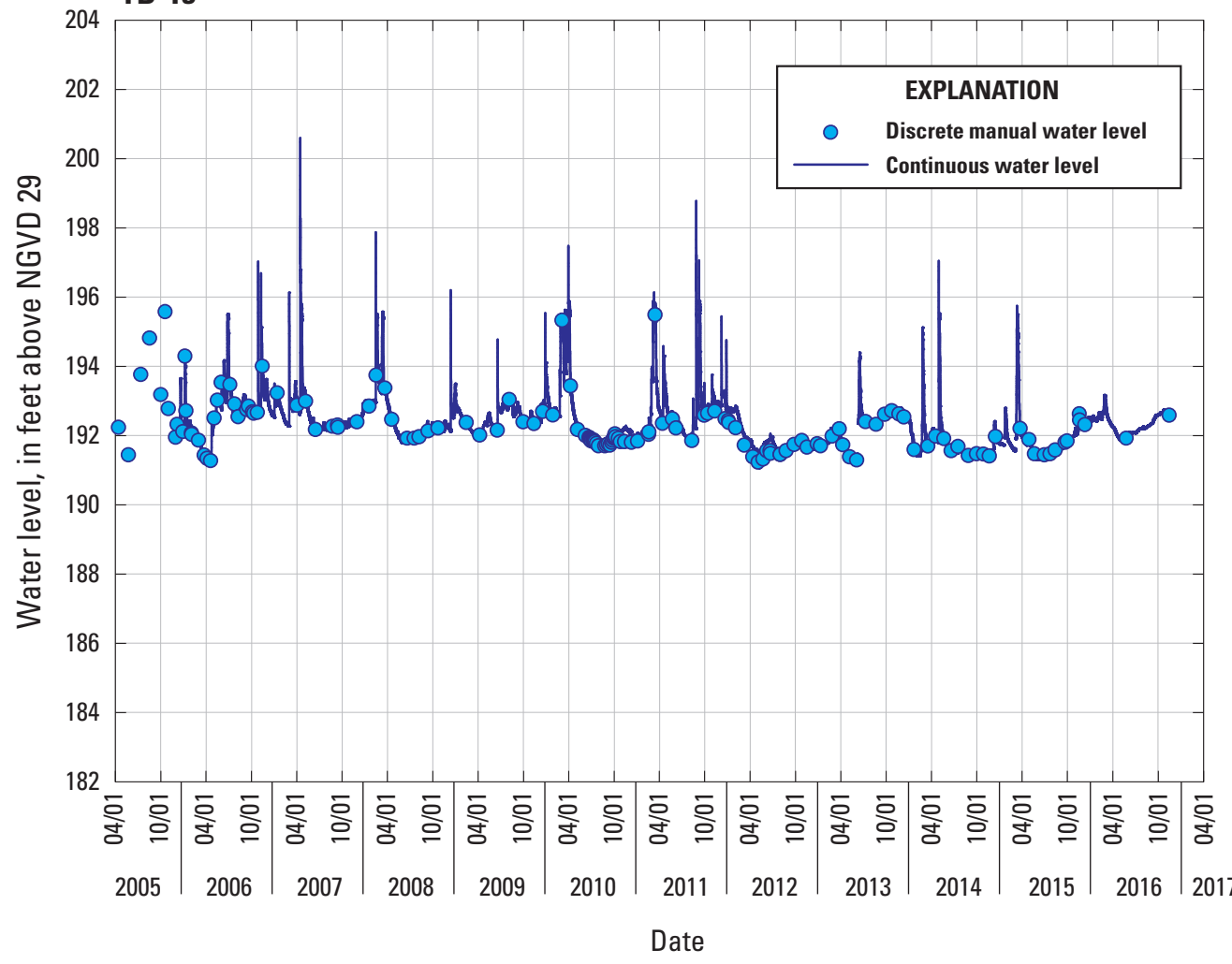

Figure 18. Discrete and continuous-record groundwaterlevel measurements for observation well TB-13 from an earthen dam site in southern Westchester County, New York. Gaps in groundwater-level record indicate no data or a dry measurement. Location of well shown on figure 2; details are listed in table 1. 


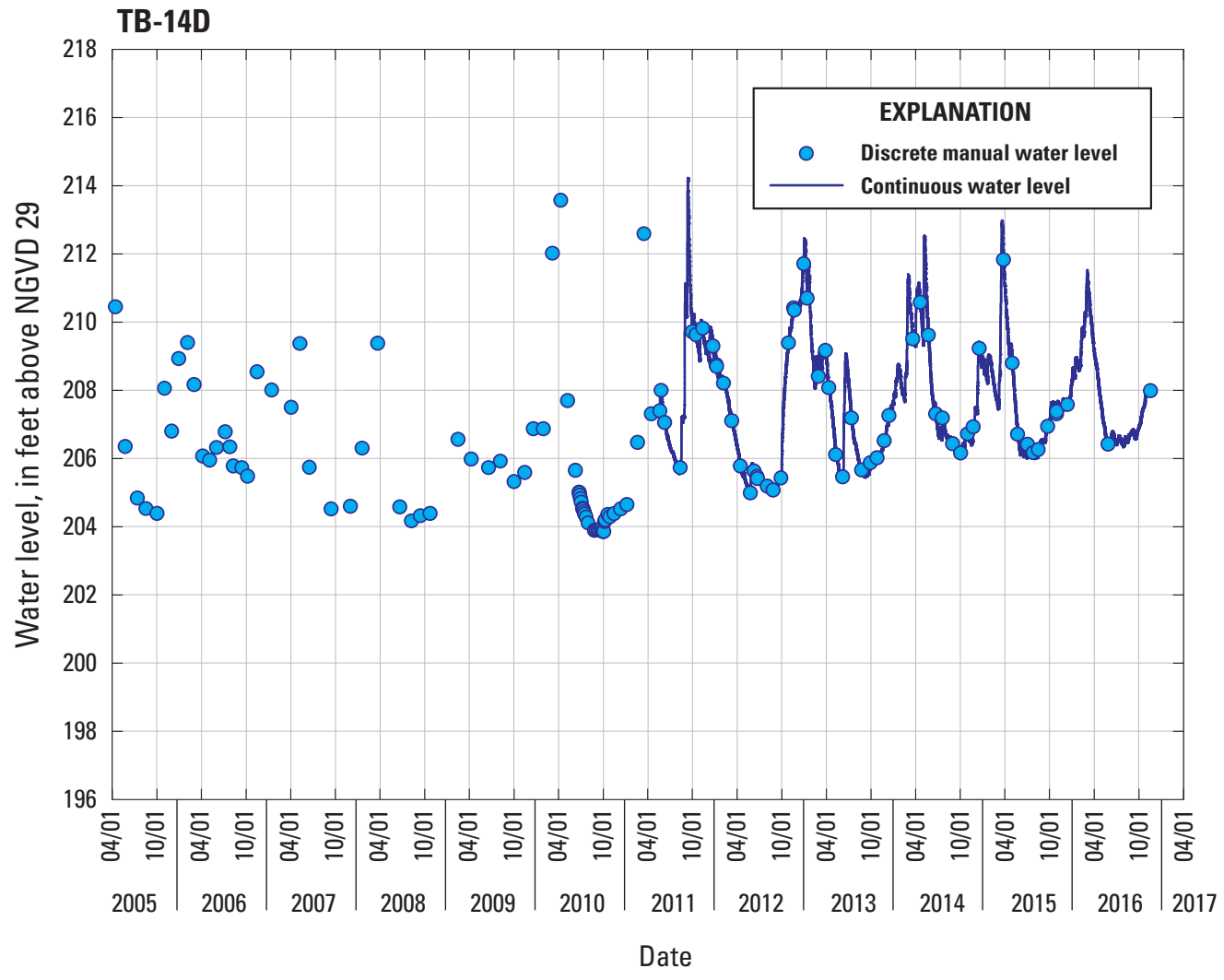

Figure 19. Discrete and continuous-record groundwaterlevel measurements for observation well TB-14D from an earthen dam site in southern Westchester County, New York. Gaps in groundwater-level record indicate no data or a dry measurement. Location of well shown on figure 2; details are listed in table 1.

\section{TB-15}

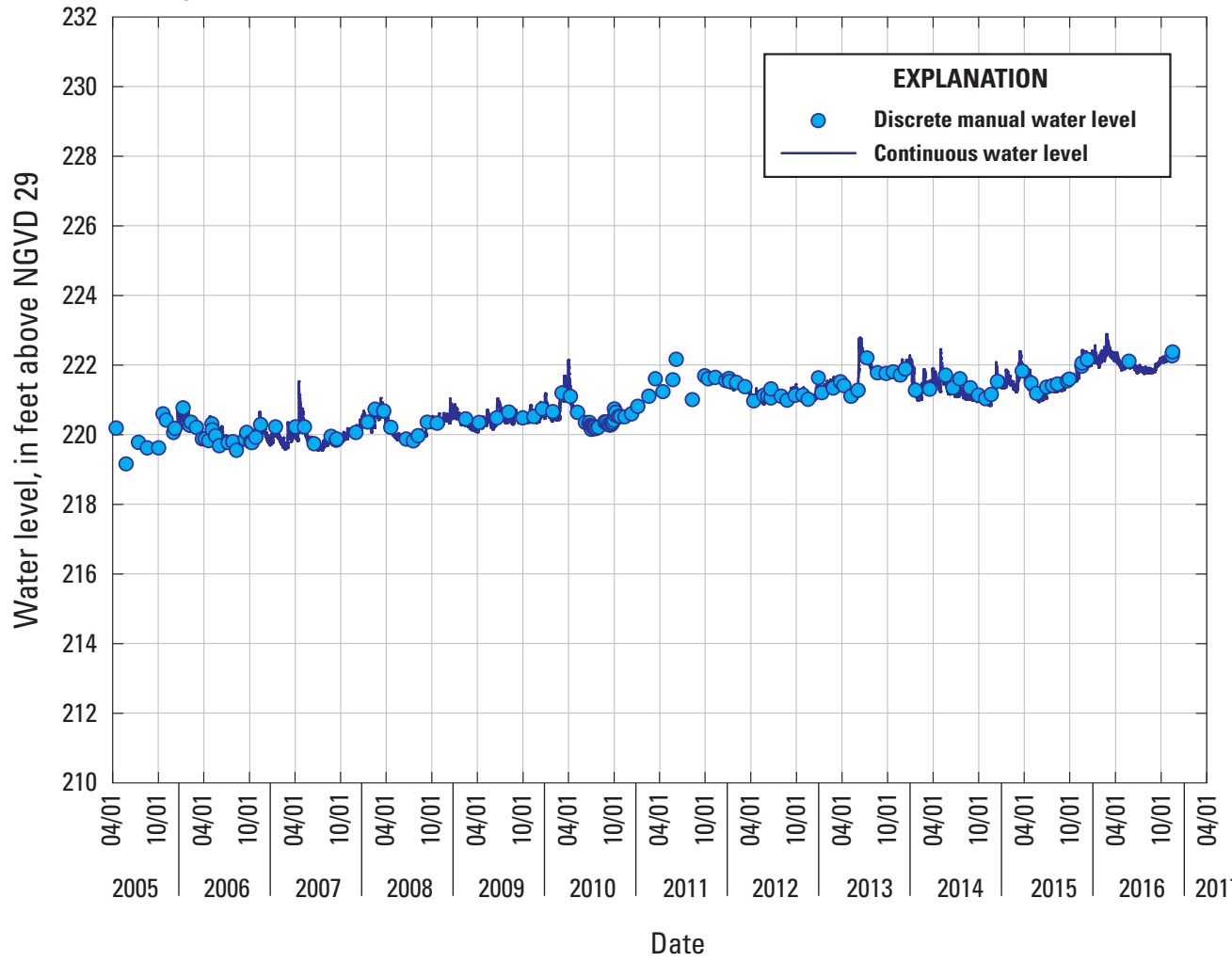

Figure 20. Discrete and continuous-record groundwaterlevel measurements for observation well TB-15 from an earthen dam site in southern Westchester County, New York. Gaps in groundwater-level record indicate no data or a dry measurement. Location of well shown on figure 2; details are listed in table 1. 


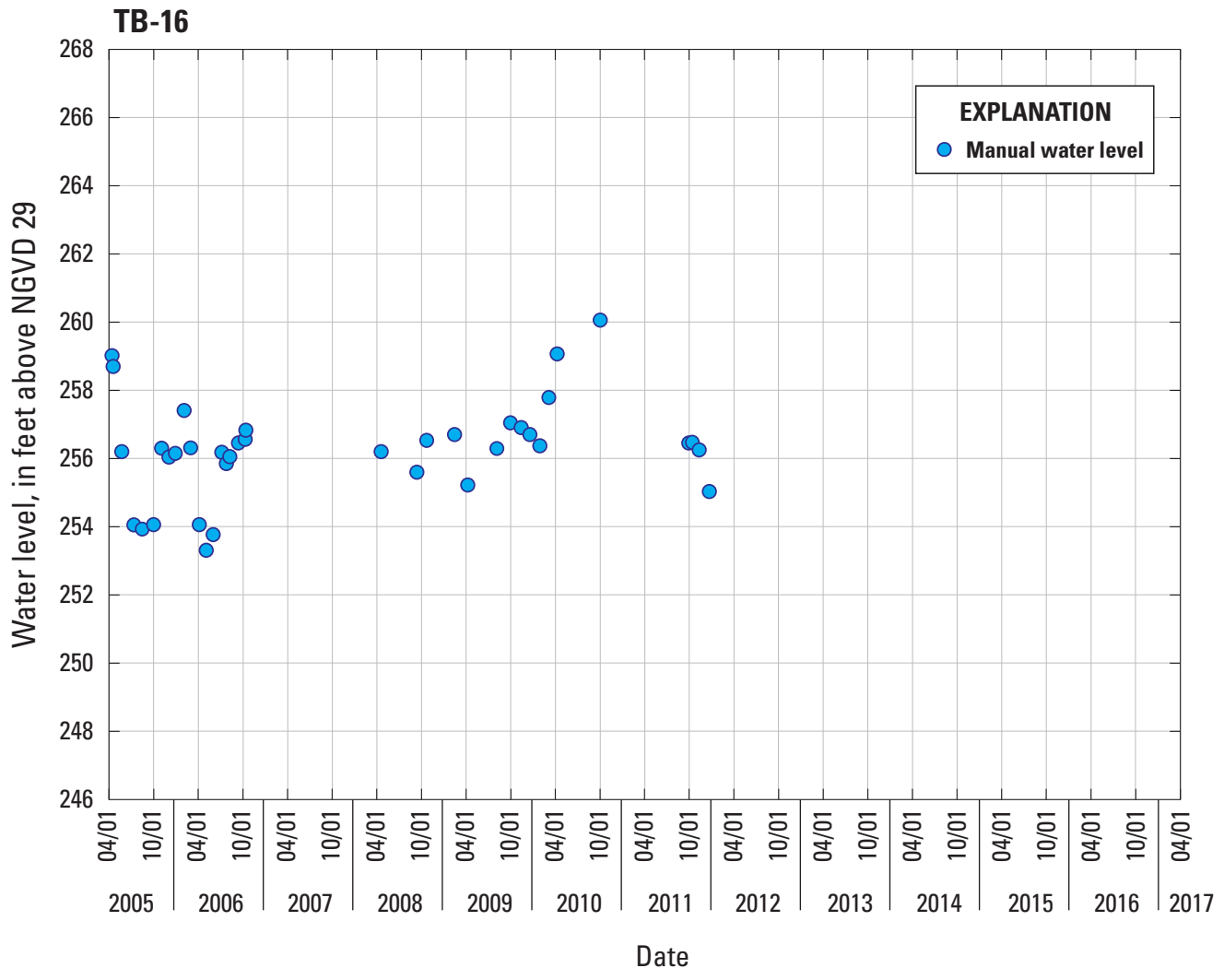

Figure 21. Discrete groundwater-level measurements for observation well TB-16 from an earthen dam site in southern Westchester County, New York. Gaps in groundwater-level record indicate no data or a dry measurement. Location of well shown on figure 2; details are listed in table 1.

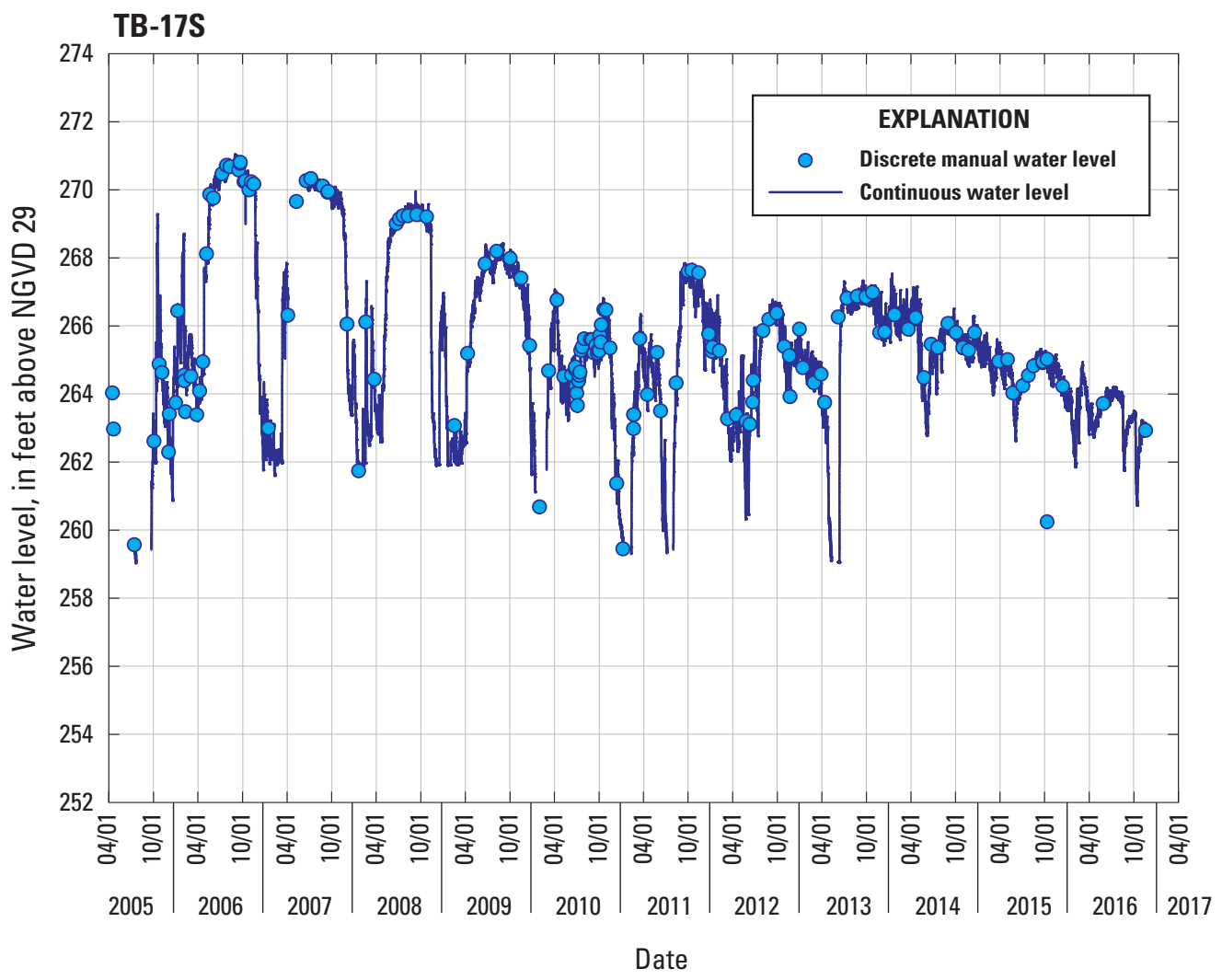

Figure 22. Discrete and continuous-record groundwaterlevel measurements for observation well TB-17S from an earthen dam site in southern Westchester County, New York. Gaps in groundwater-level record indicate no data or a dry measurement. Location of well shown on figure 2; details are listed in table 1. 


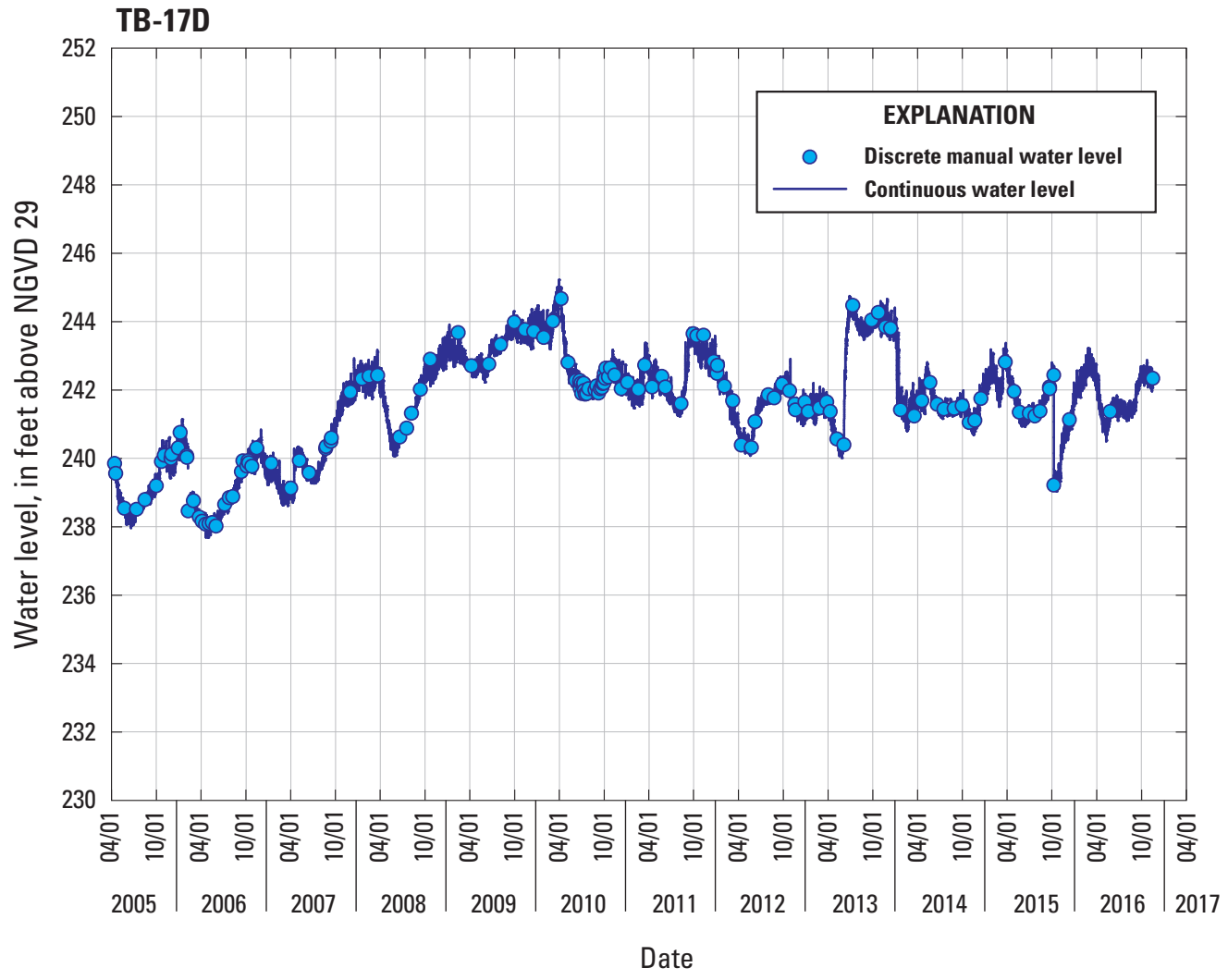

Figure 23. Discrete and continuous-record groundwaterlevel measurements for observation well TB-17D from an earthen dam site in southern Westchester County, New York. Gaps in groundwater-level record indicate no data or a dry measurement. Location of well shown on figure 2; details are listed in table 1.

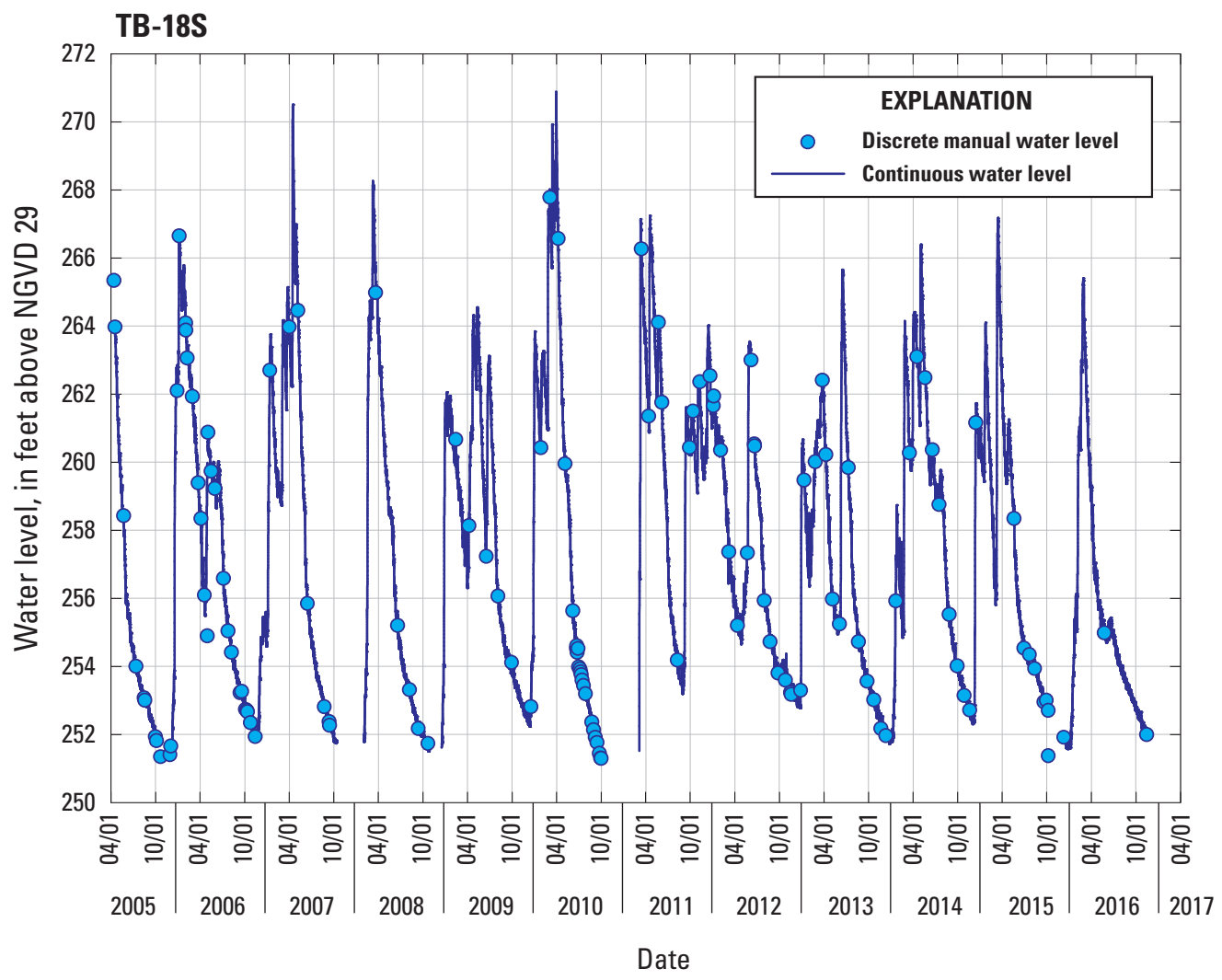

Figure 24. Discrete and continuous-record groundwaterlevel measurements for observation well TB-18S from an earthen dam site in southern Westchester County, New York. Gaps in groundwater-level record indicate no data or a dry measurement. Location of well shown on figure 2; details are listed in table 1. 
TB-18D

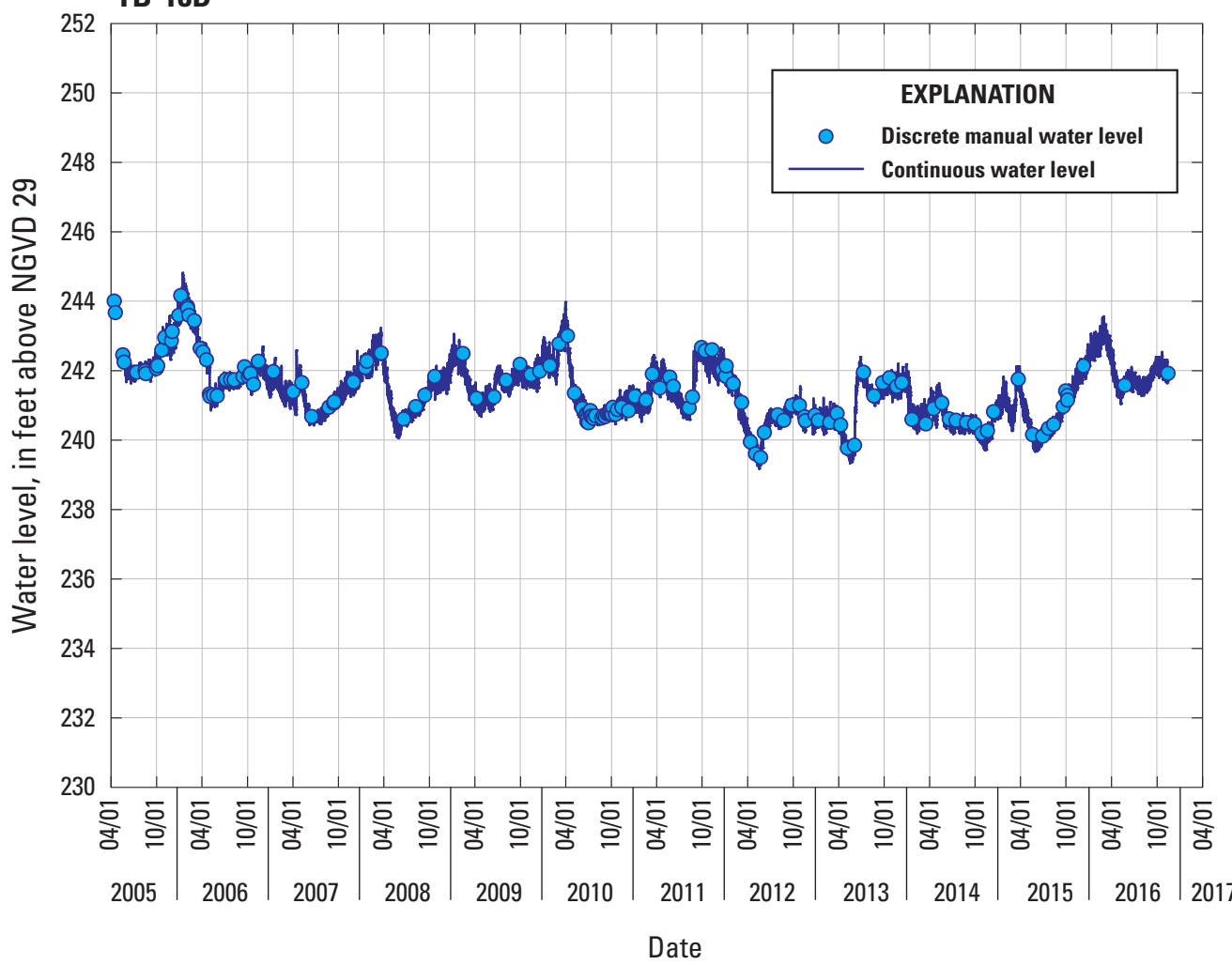

Figure 25. Discrete and continuous-record groundwaterlevel measurements for observation well TB-18D from an earthen dam site in southern Westchester County, New York. Gaps in groundwater-level record indicate no data or a dry measurement. Location of well shown on figure 2; details are listed in table 1.

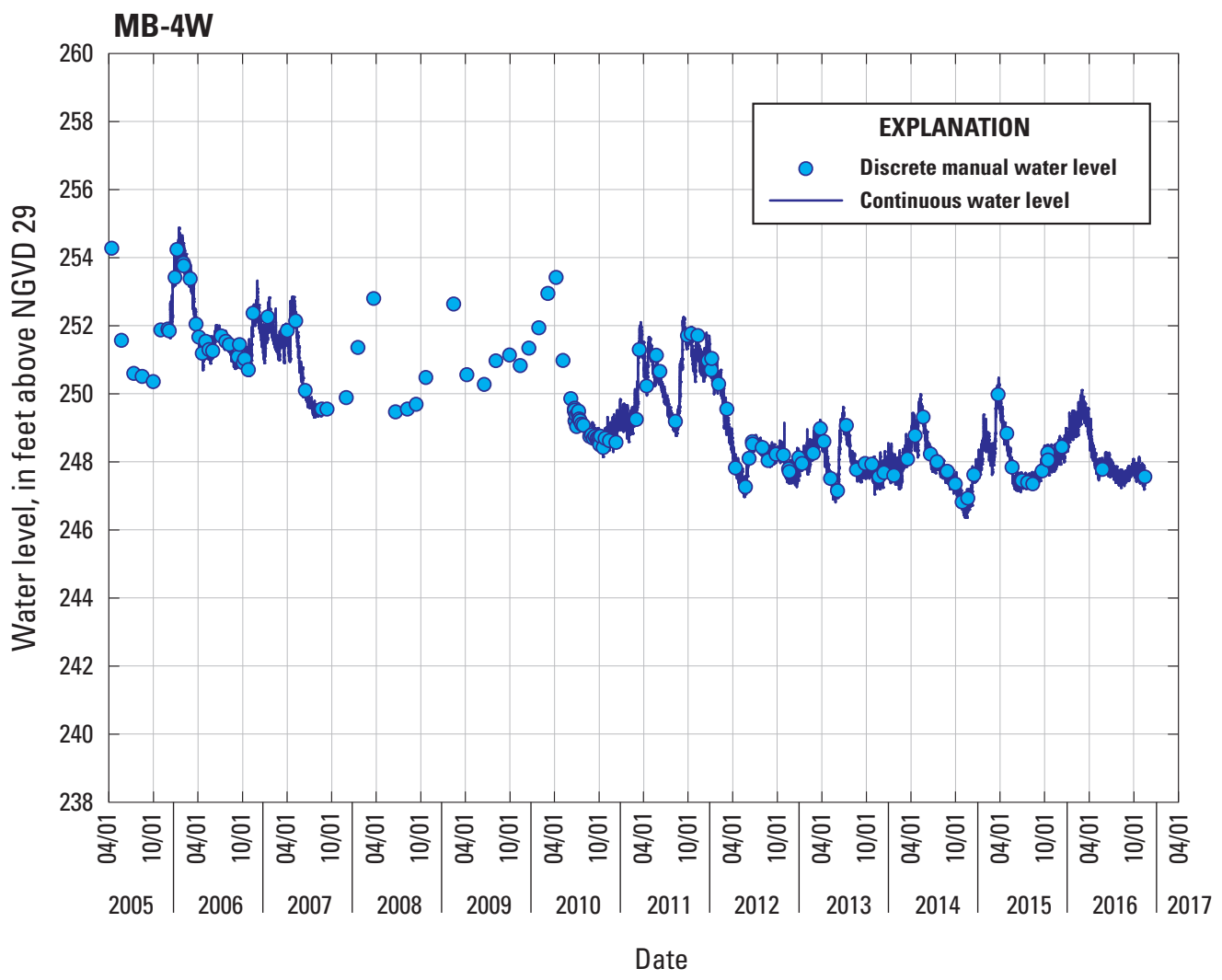

Figure 26. Discrete and continuous-record groundwaterlevel measurements for observation well MB-4W from an earthen dam site in southern Westchester County, New York. Gaps in groundwater-level record indicate no data or a dry measurement. Location of well shown on figure 2; details are listed in table 1. 


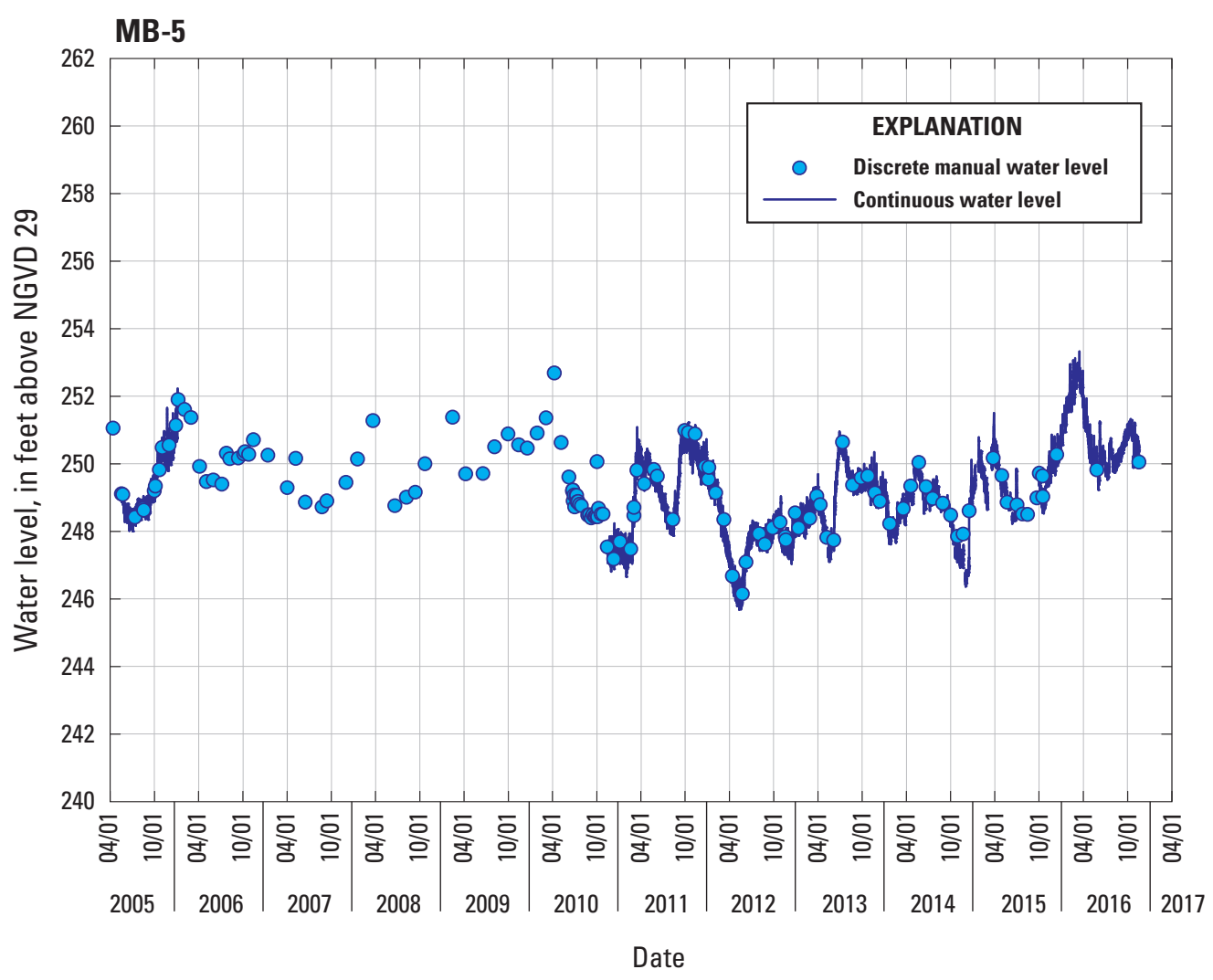

Figure 27. Discrete and continuous-record groundwaterlevel measurements for observation well MB-5 from an earthen dam site in southern Westchester County, New York. Gaps in groundwater-level record indicate no data or a dry measurement. Location of well shown on figure 2; details are listed in table 1.

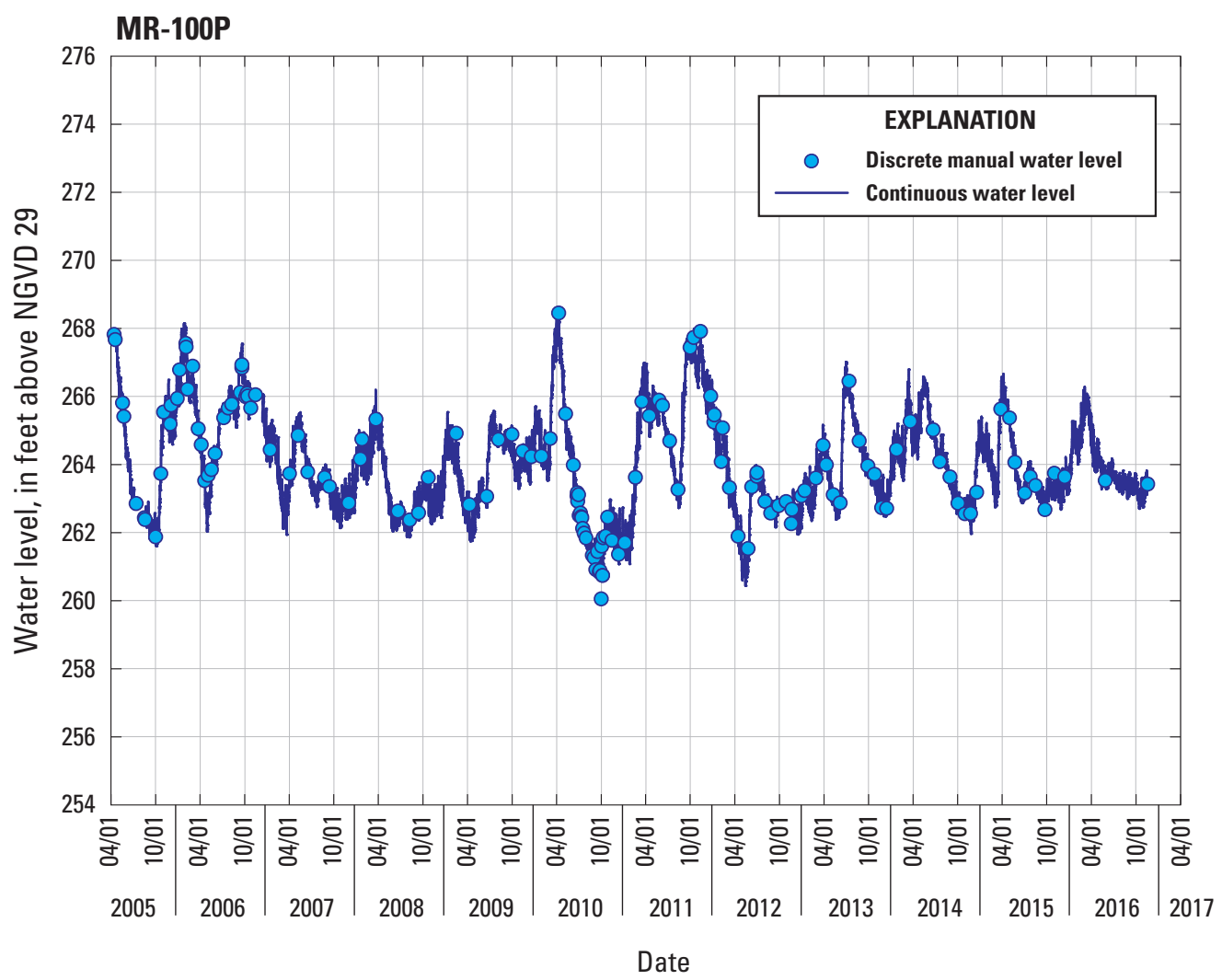

Figure 28. Discrete and continuous-record groundwaterlevel measurements for observation well MR-100P from an earthen dam site in southern Westchester County, New York. Gaps in groundwater-level record indicate no data or a dry measurement. Location of well shown on figure 2; details are listed in table 1. 


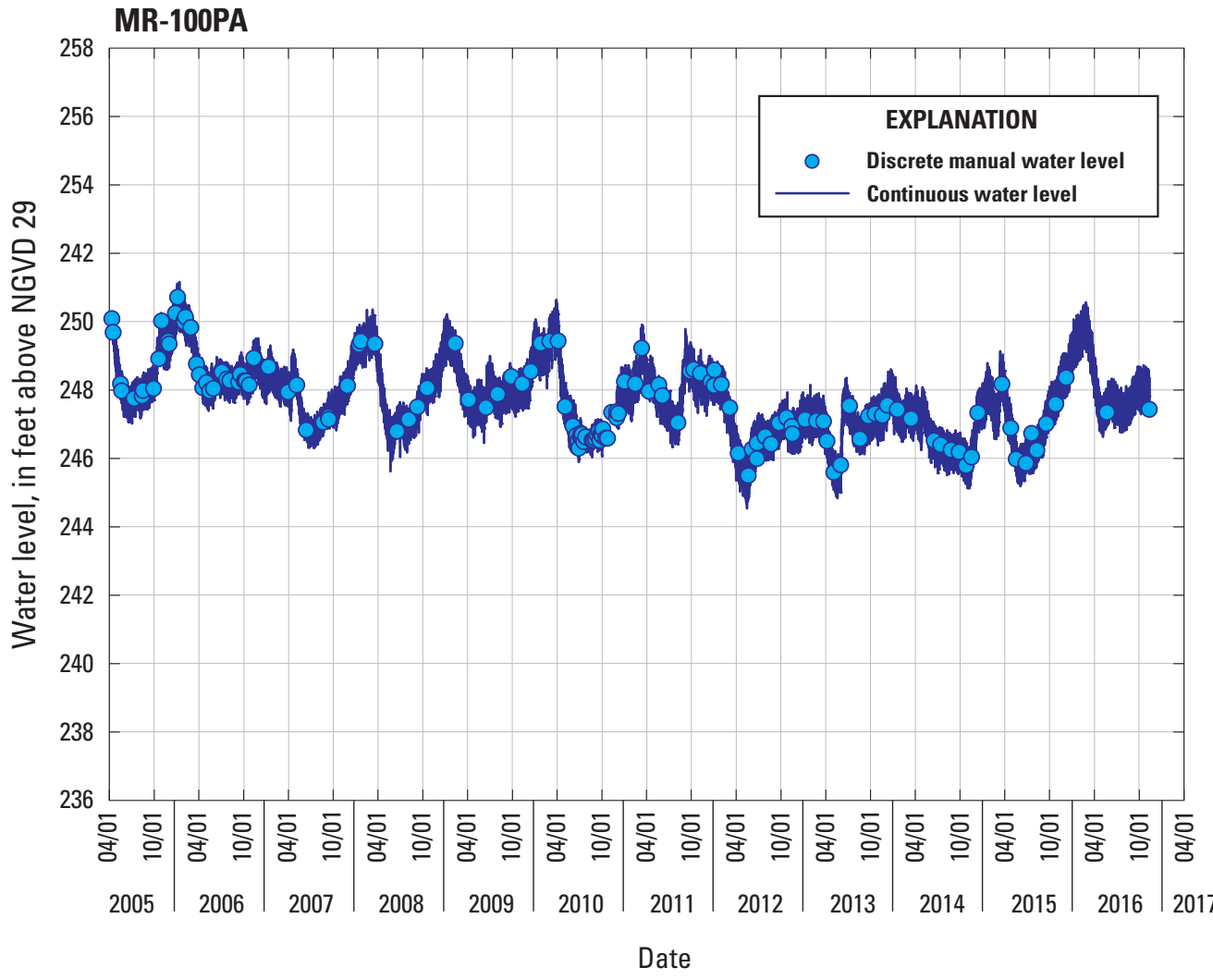

Figure 29. Discrete and continuous-record groundwaterlevel measurements for observation well MR-100PA from an earthen dam site in southern Westchester County, New York. Gaps in groundwater-level record indicate no data or a dry measurement. Location of well shown on figure 2; details are listed in table 1.
MR-121

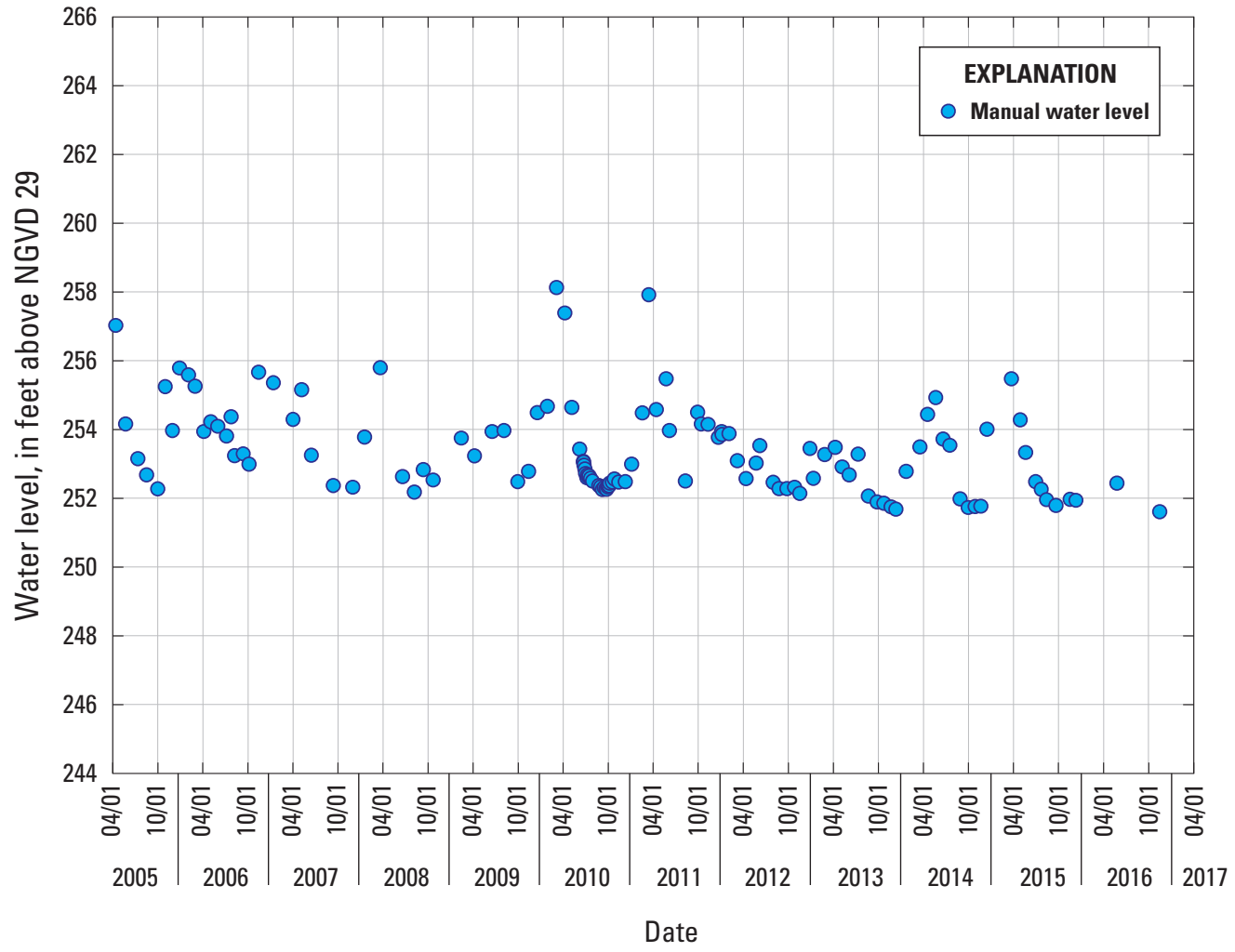

Figure 30. Discrete groundwater-level measurements for observation well MR-121 from an earthen dam site in southern Westchester County, New York. Gaps in groundwater-level record indicate no data or a dry measurement. Location of well shown on figure 2; details are listed in table 1. 


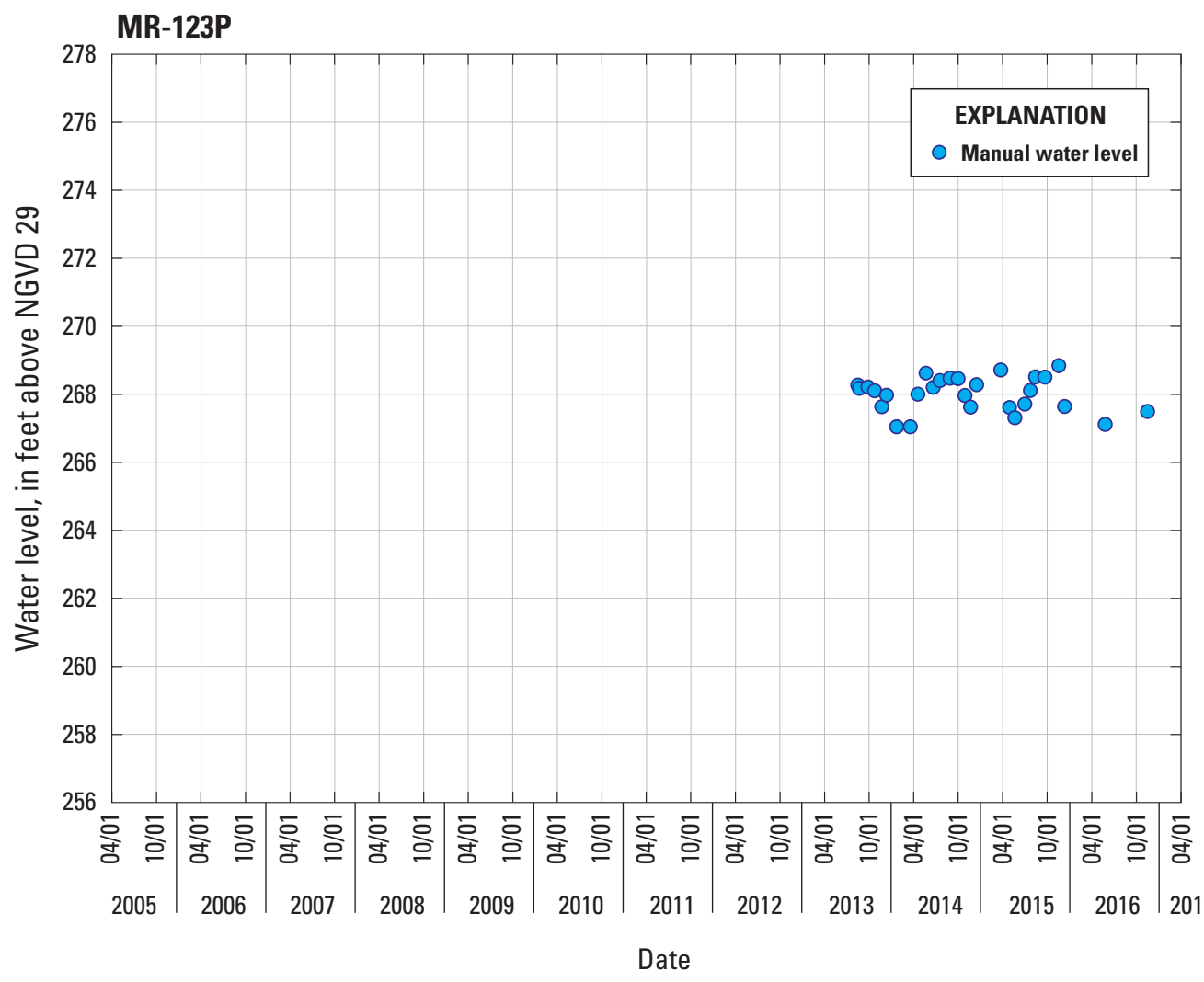

MR-123PA

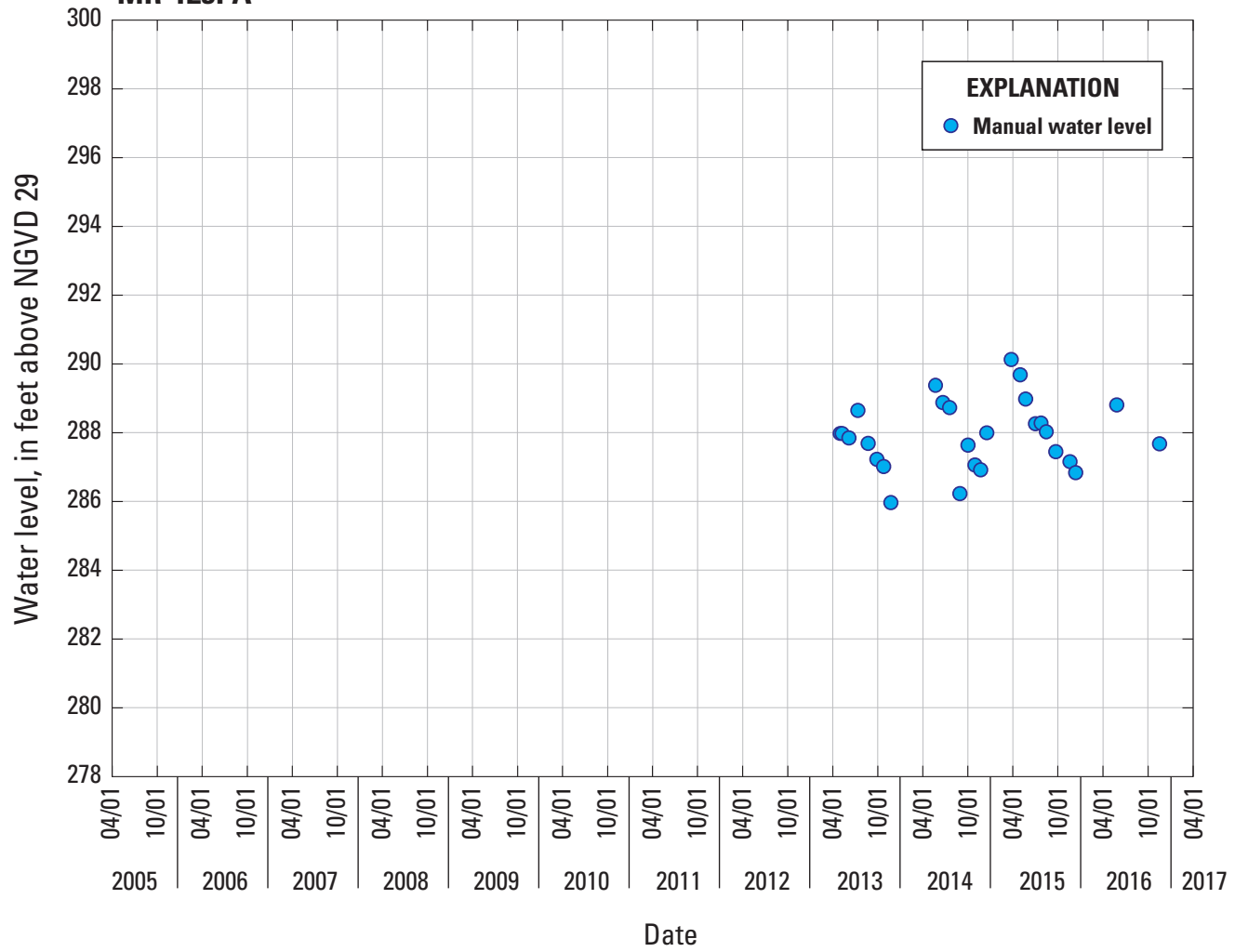

Figure 31. Discrete groundwater-level measurements for observation well MR-123P from an earthen dam site in southern Westchester County, New York. Gaps in groundwater-level record indicate no data or a dry measurement. Location of well shown on figure 2; details are listed in table 1.
Figure 32. Discrete groundwater-level measurements for observation well MR-123PA from an earthen dam site in southern Westchester County, New York. Gaps in groundwater-level record indicate no data or a dry measurement. Location of well shown on figure 2; details are listed in table 1. 


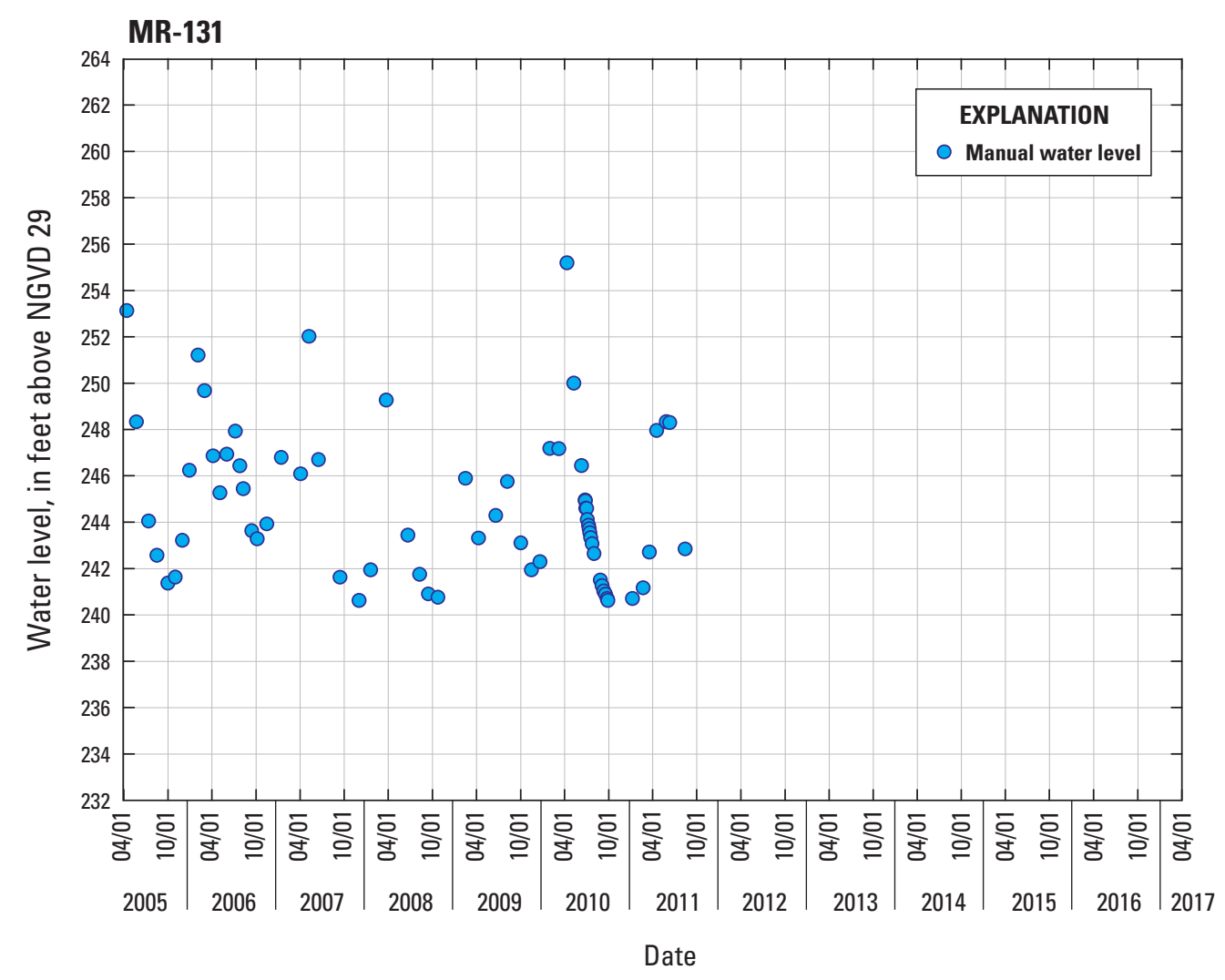

Figure 33. Discrete groundwater-level measurements for observation well MR-131 from an earthen dam site in southern Westchester County, New York. Gaps in groundwater-level record indicate no data or a dry measurement. Location of well shown on figure 1; details are listed in table 1.

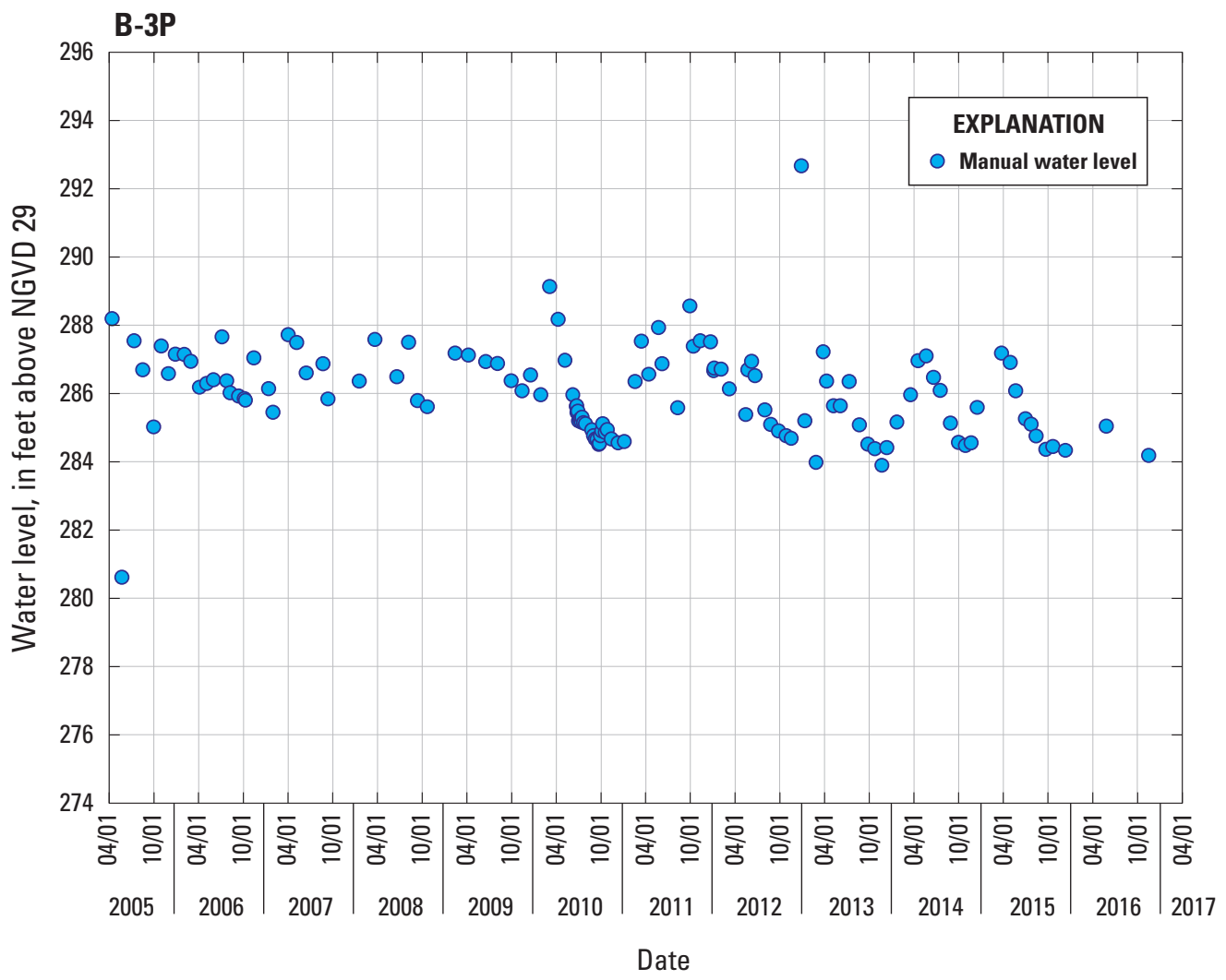

Figure 34. Discrete groundwater-level measurements for observation well B-3P from an earthen dam site in southern Westchester County, New York. Gaps in groundwater-level record indicate no data or a dry measurement. Location of well shown on figure 2; details are listed in table 1. 


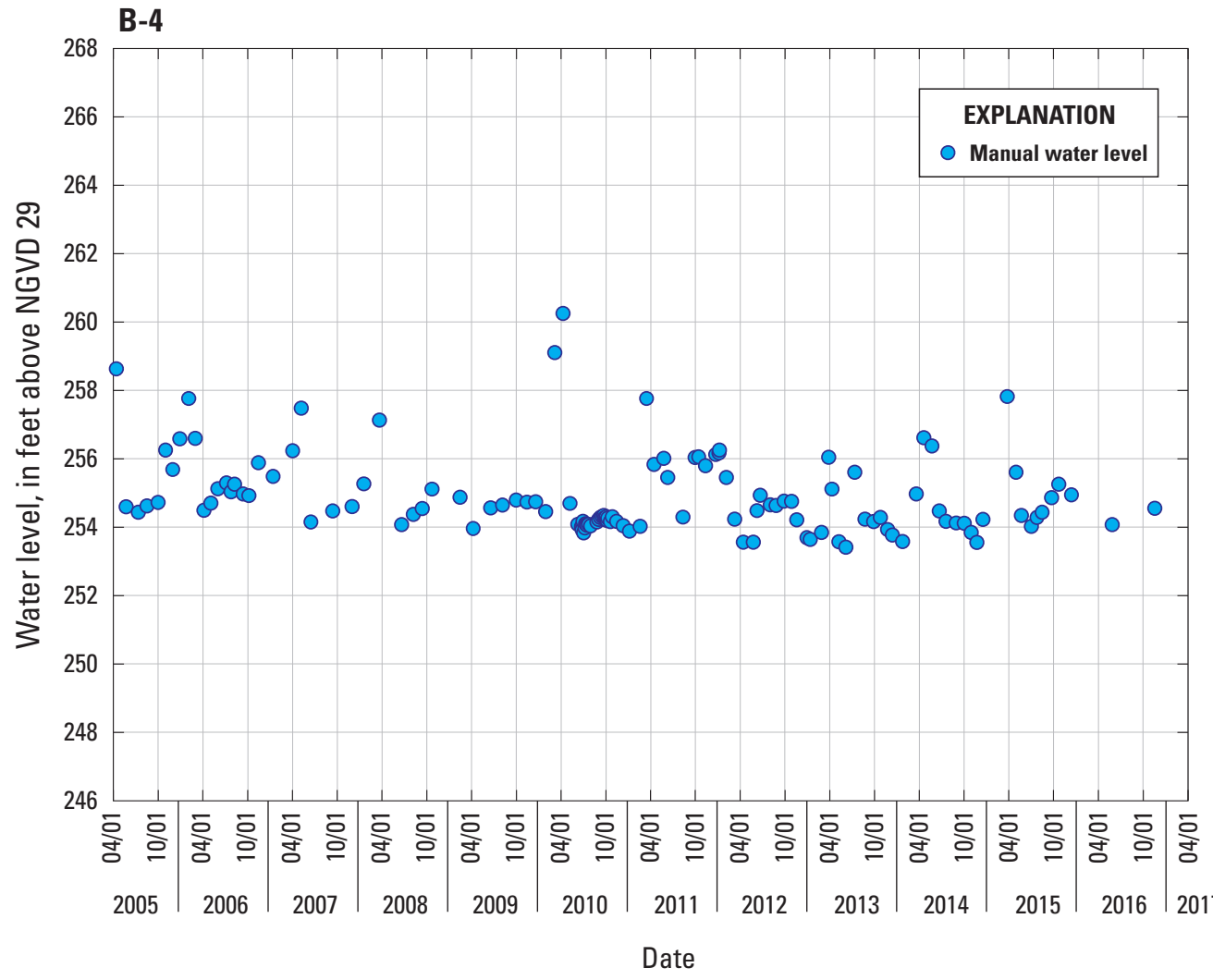

Figure 35. Discrete groundwater-level measurements for observation well B-4 from an earthen dam site in southern Westchester County, New York. Gaps in groundwater-level record indicate no data or a dry measurement. Location of well shown on figure 2; details are listed in table 1.

\section{B-5A}

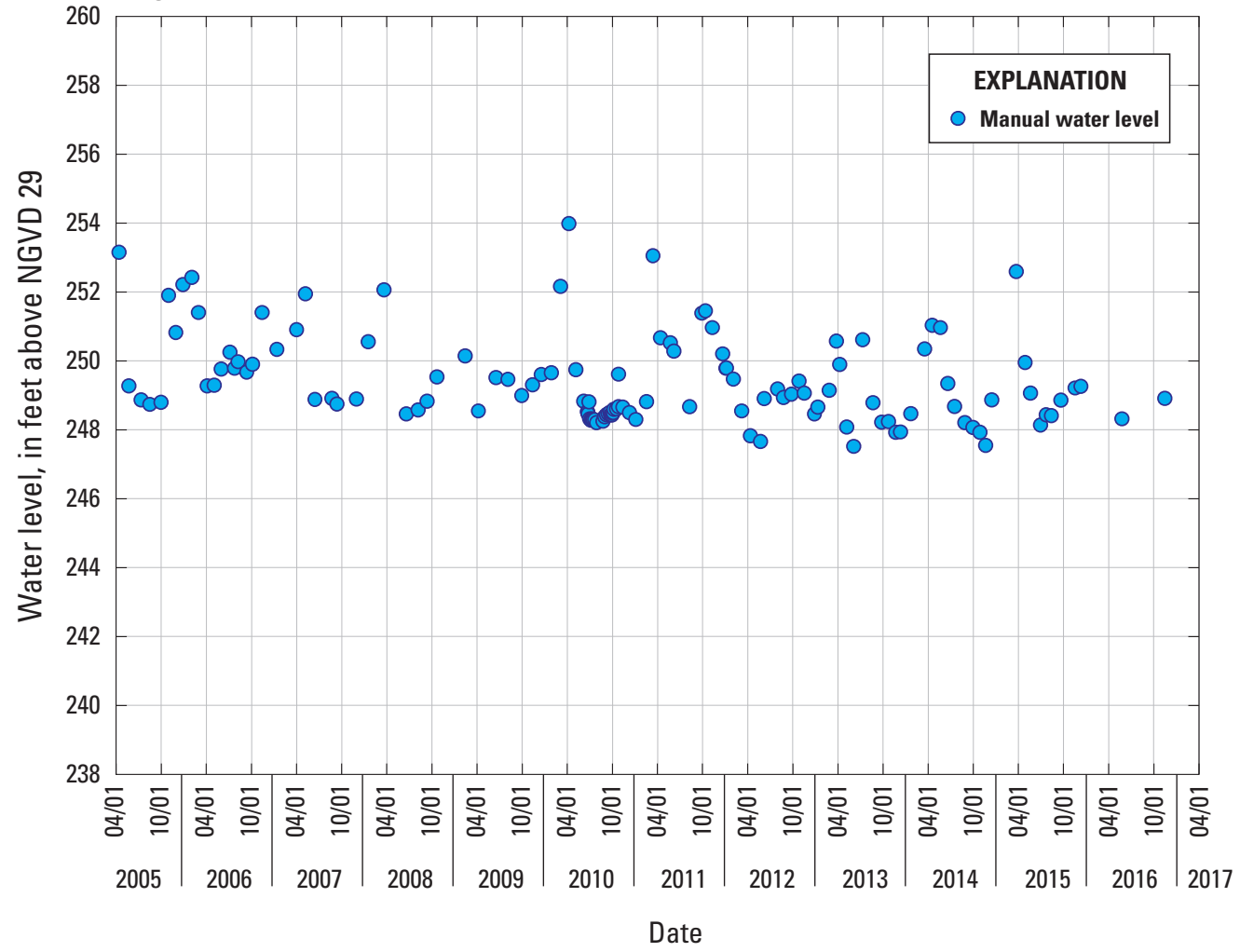

Figure 36. Discrete groundwater-level measurements for observation well B-5A from an earthen dam site in southern Westchester County, New York. Gaps in groundwater-level record indicate no data or a dry measurement. Location of well shown on figure 2; details are listed in table 1. 


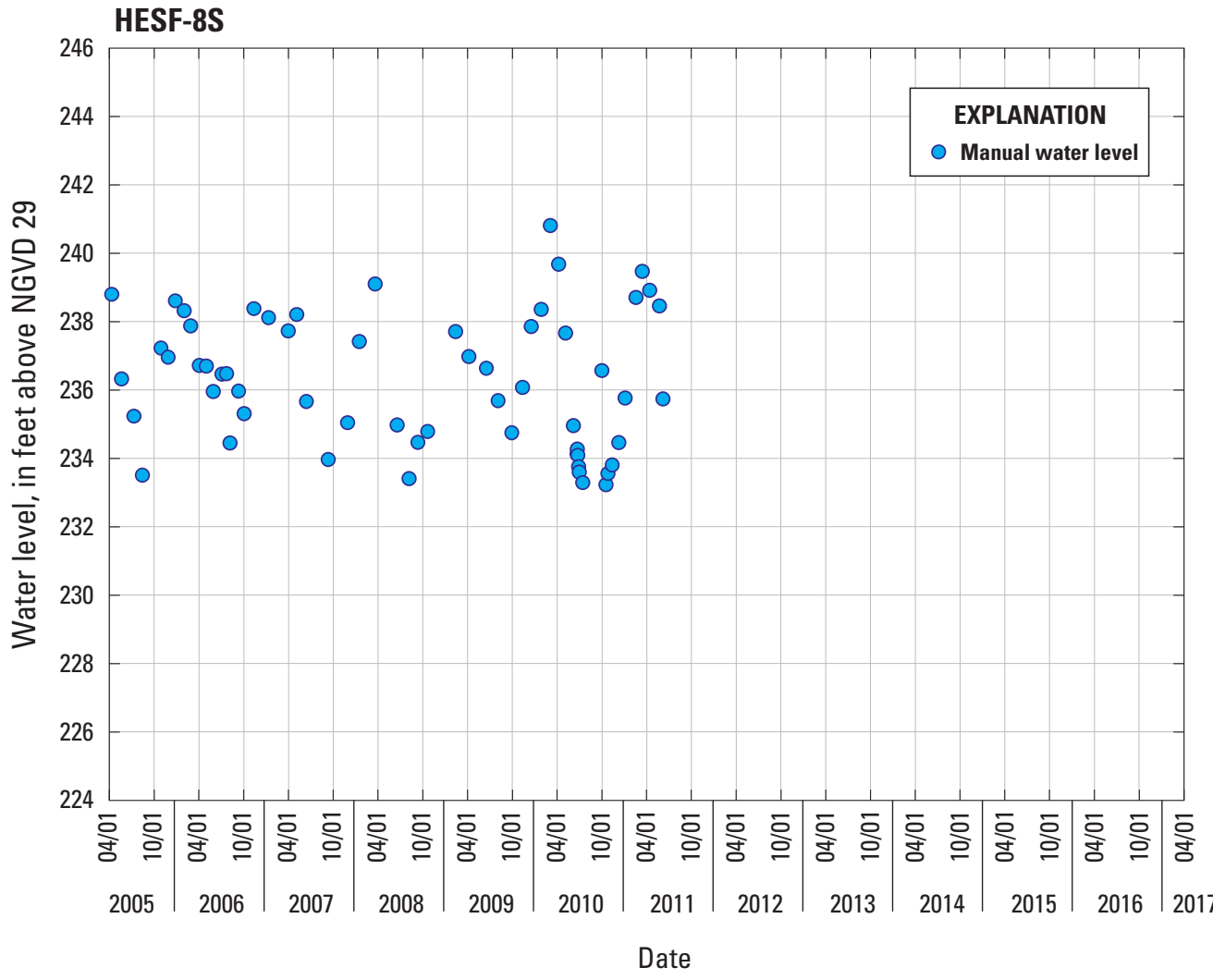

HESF-8D

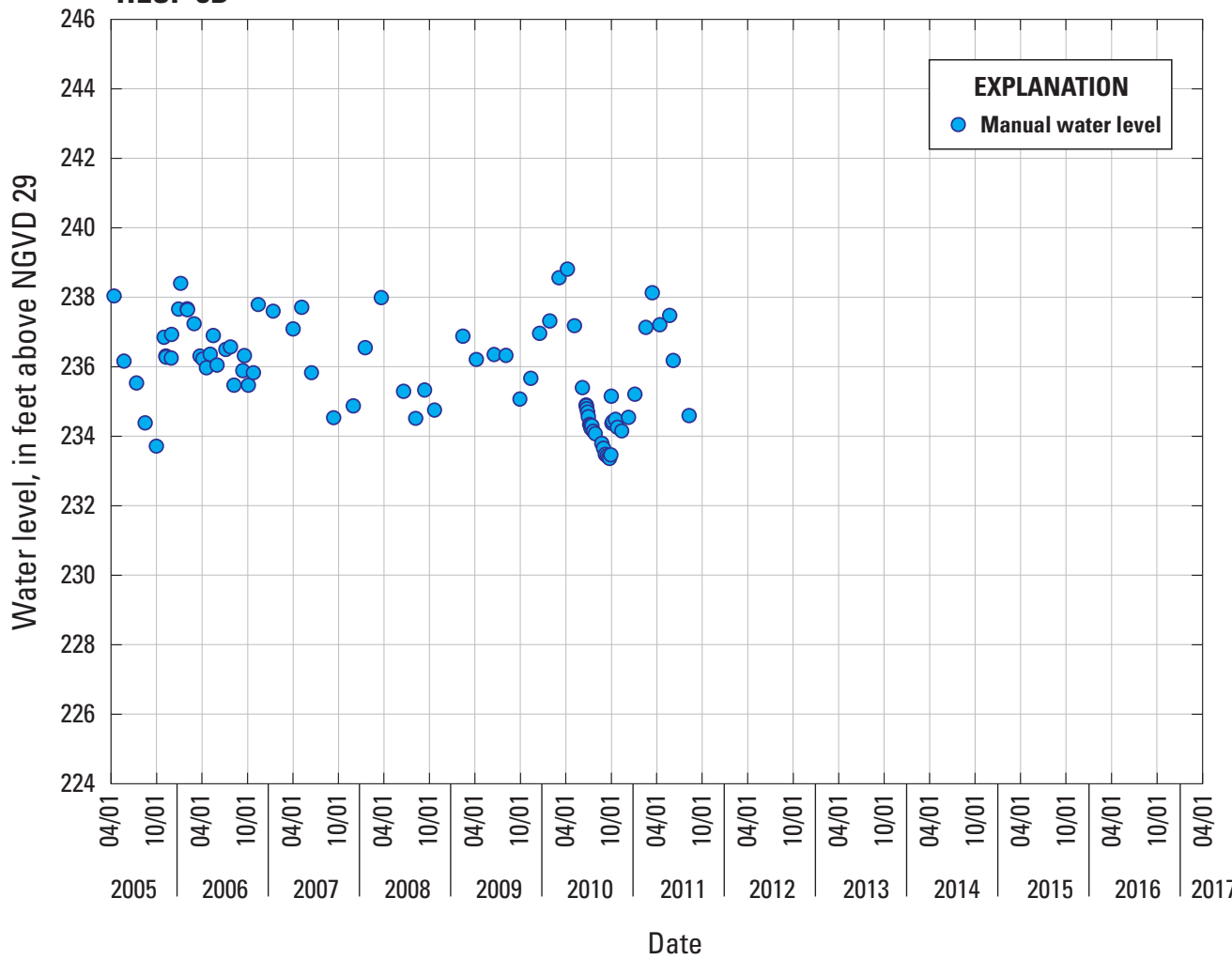

Figure 37. Discrete groundwater-level measurements for observation well HESF-8S from an earthen dam site in southern Westchester County, New York. Gaps in groundwater-level record indicate no data or a dry measurement. Location of well shown on figure 1; details are listed in table 1.
Figure 38. Discrete groundwater-level measurements for observation well HESF-8D from an earthen dam site in southern Westchester County, New York. Gaps in groundwater-level record indicate no data or a dry measurement. Location of well shown on figure 1; details are listed in table 1. 


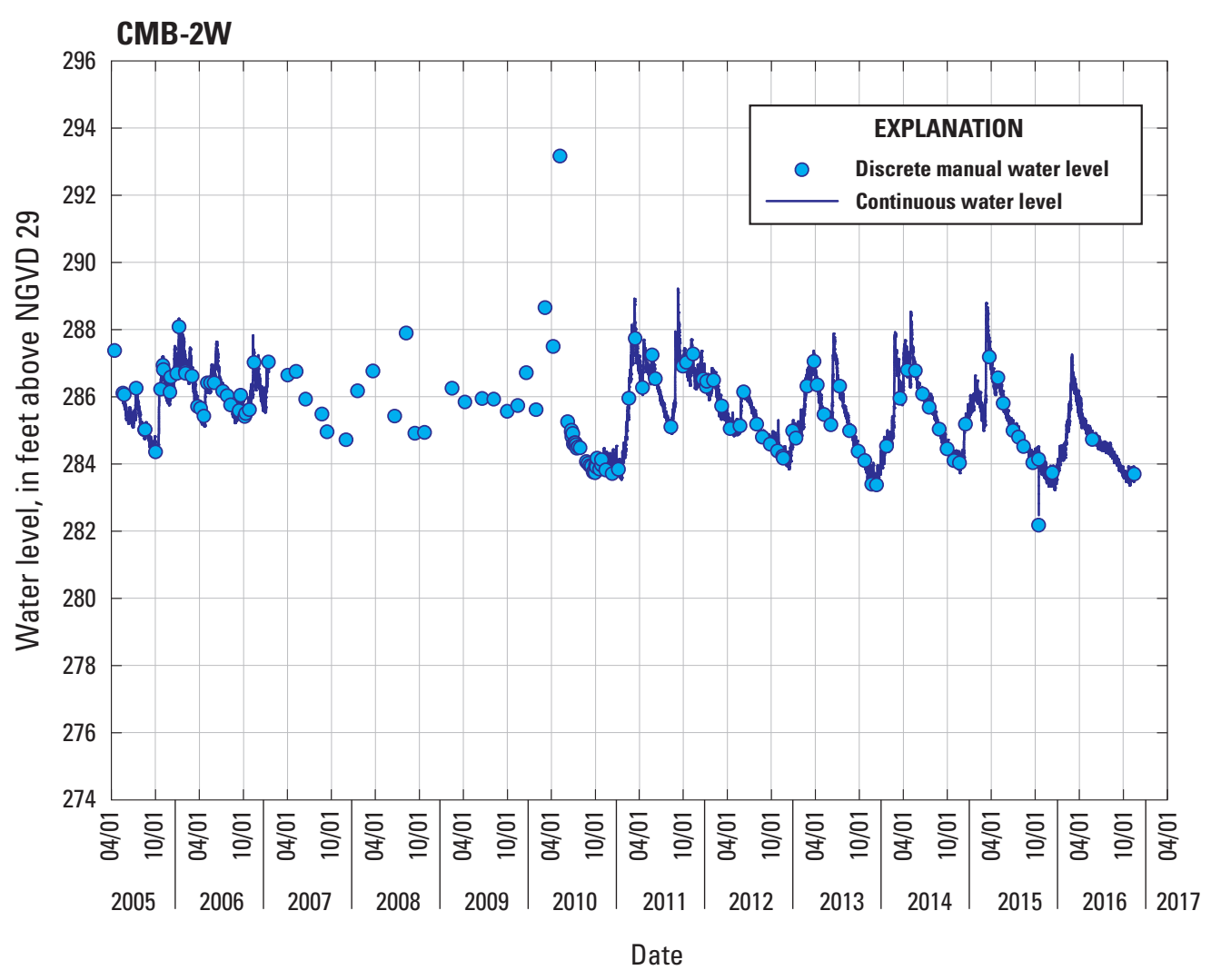

Figure 39. Discrete and continuous-record groundwaterlevel measurements for observation well CMB-2W from an earthen dam site in southern Westchester County, New York. Gaps in groundwater-level record indicate no data or a dry measurement. Location of well shown on figure 2; details are listed in table 1.

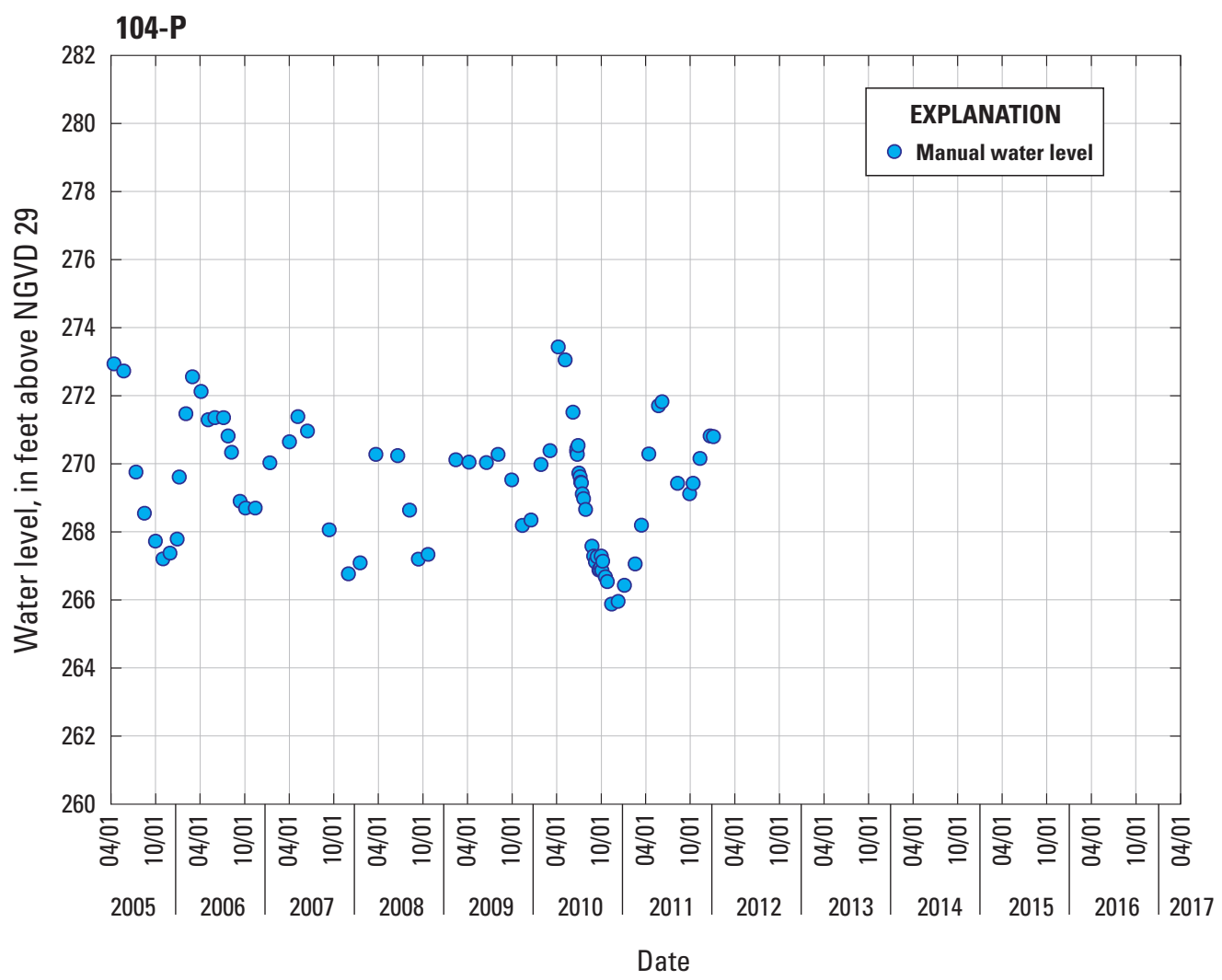

Figure 40. Discrete groundwater-level measurements for observation well 104-P from an earthen dam site in southern Westchester County, New York. Gaps in groundwater-level record indicate no data or a dry measurement. Location of well shown on figure 1; details are listed in table 1. 


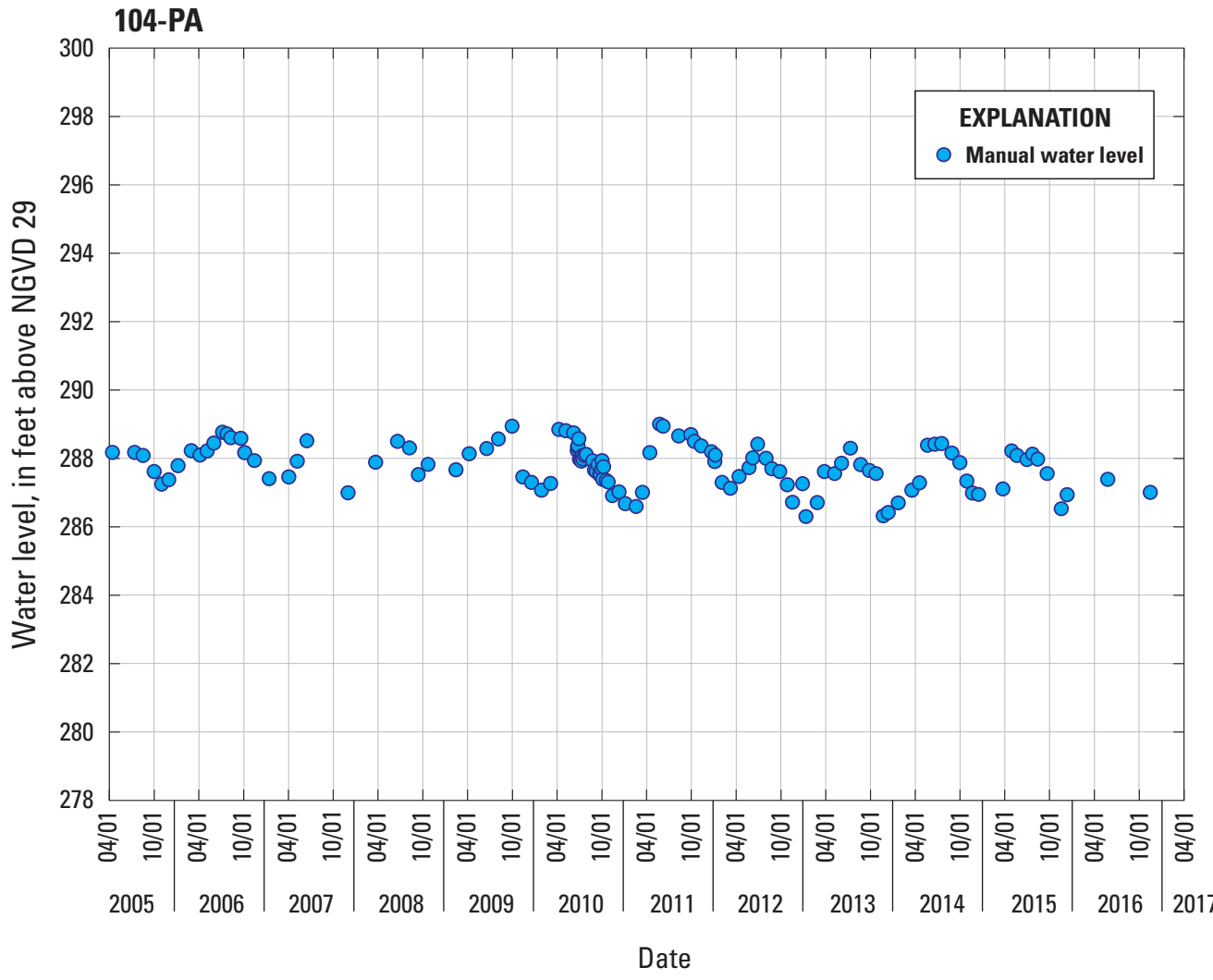

Figure 41. Discrete groundwater-level measurements for observation well 104-PA from an earthen dam site in southern Westchester County, New York. Gaps in groundwater-level record indicate no data or a dry measurement. Location of well shown on figure 1 ; details are listed in table 1.

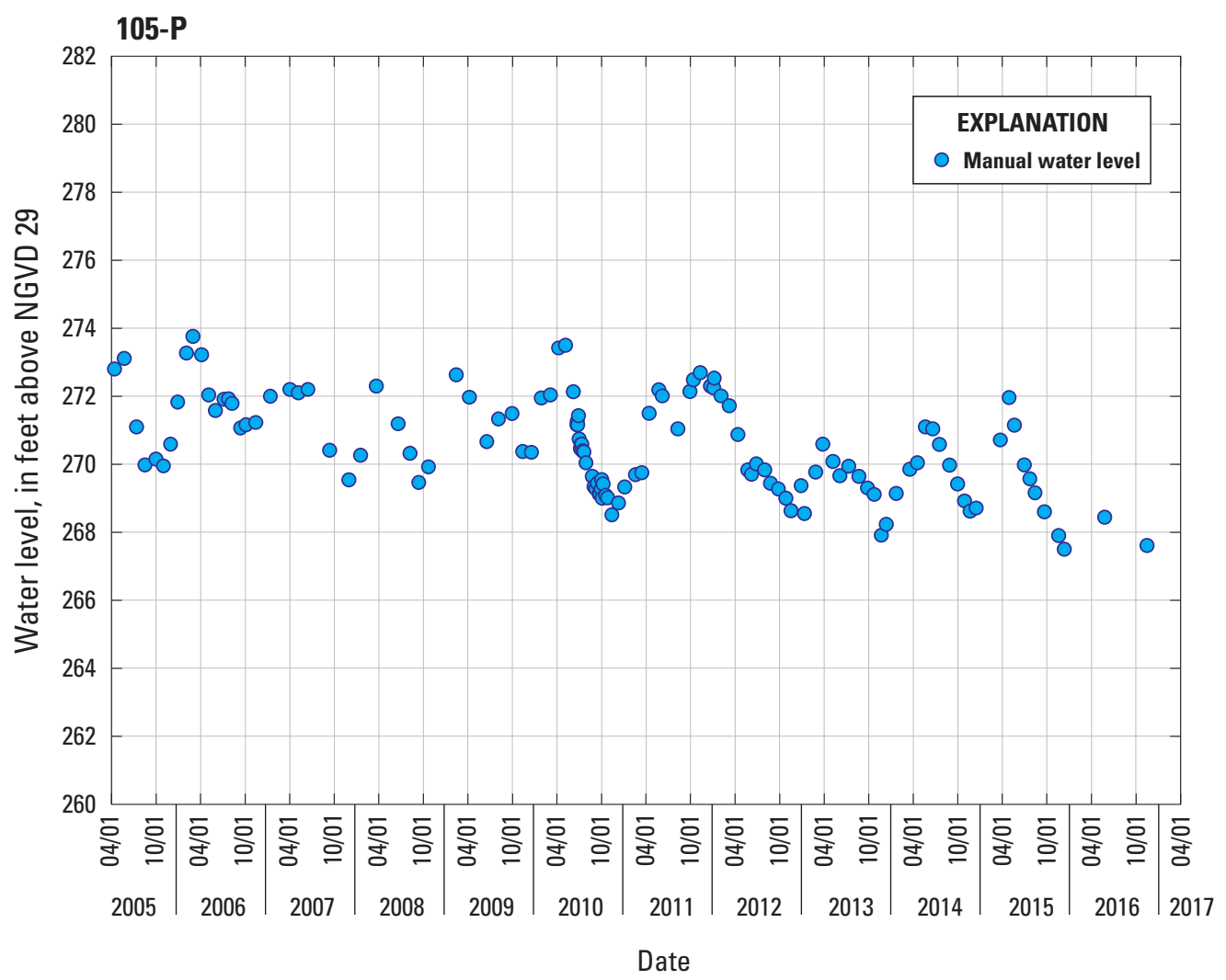

Figure 42. Discrete groundwater-level measurements for observation well 105-P from an earthen dam site in southern Westchester County, New York. Gaps in groundwater-level record indicate no data or a dry measurement. Location of well shown on figure 1; details are listed in table 1. 


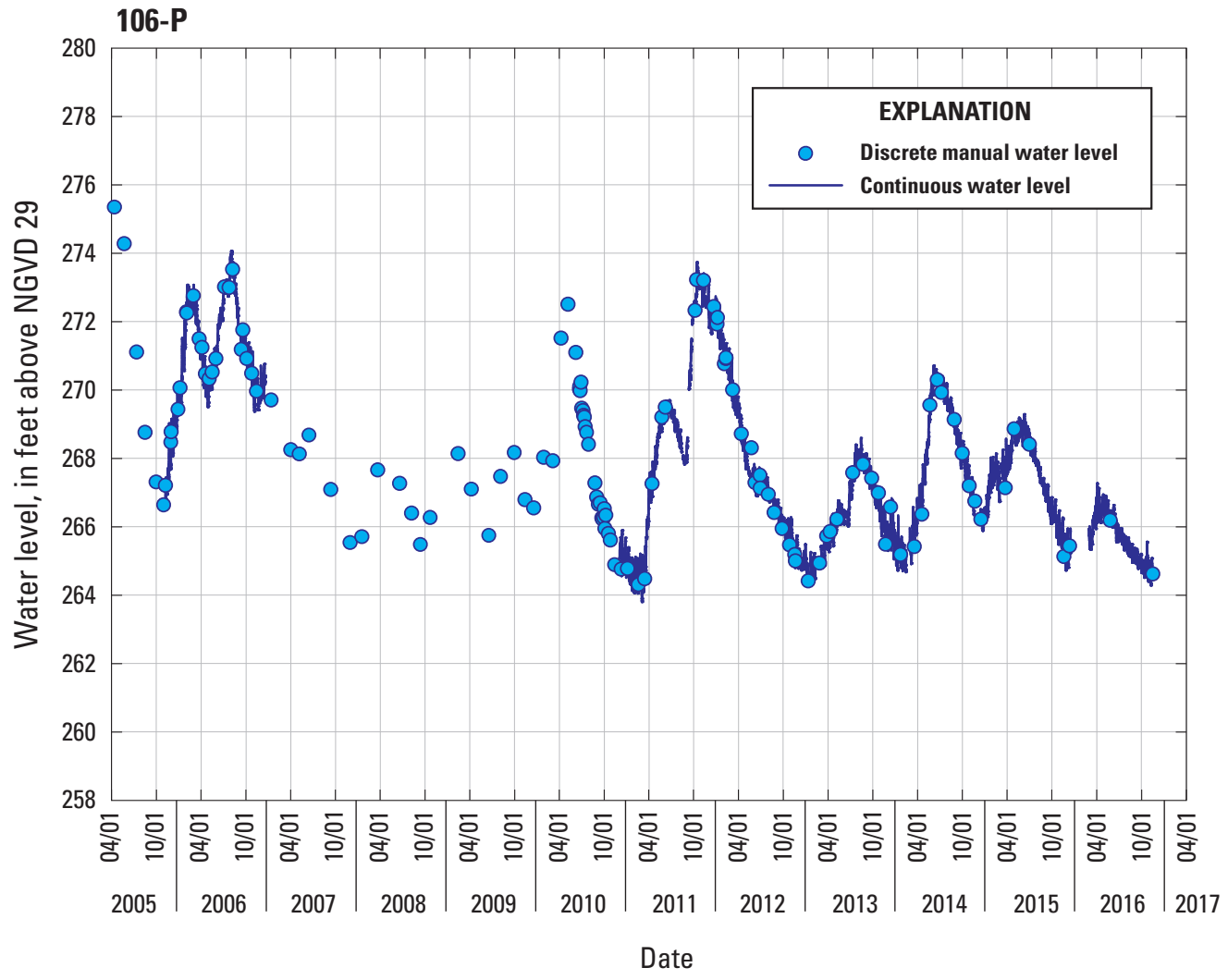

Figure 43. Discrete and continuous-record groundwaterlevel measurements for observation well 106-P from an earthen dam site in southern Westchester County, New York. Gaps in groundwater-level record indicate no data or a dry measurement. Location of well shown on figure 1; details are listed in table 1.
109-P

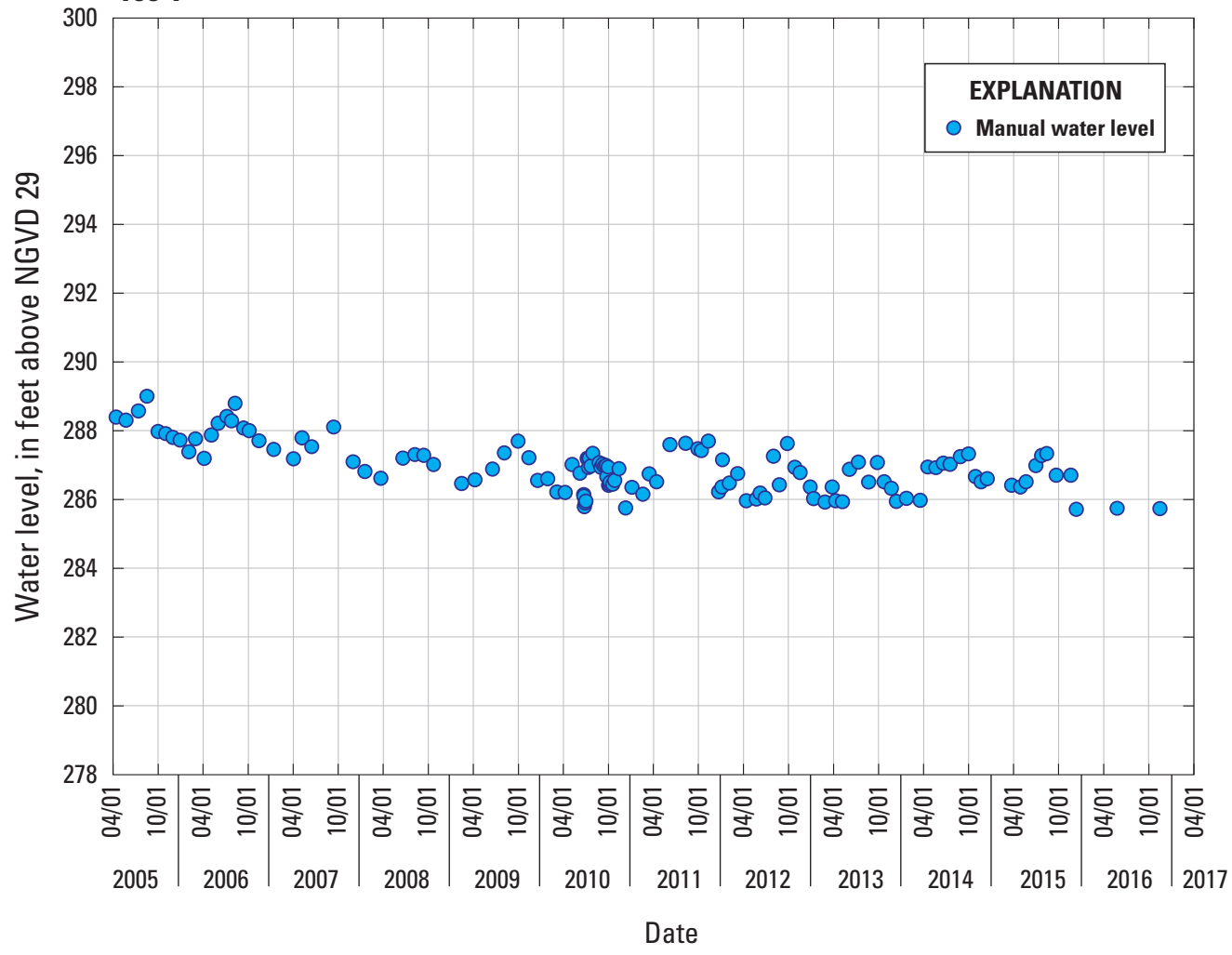

Figure 44. Discrete groundwater-level measurements for observation well 109-P from an earthen dam site in southern Westchester County, New York. Gaps in groundwater-level record indicate no data or a dry measurement. Location of well shown on figure 1; details are listed in table 1. 


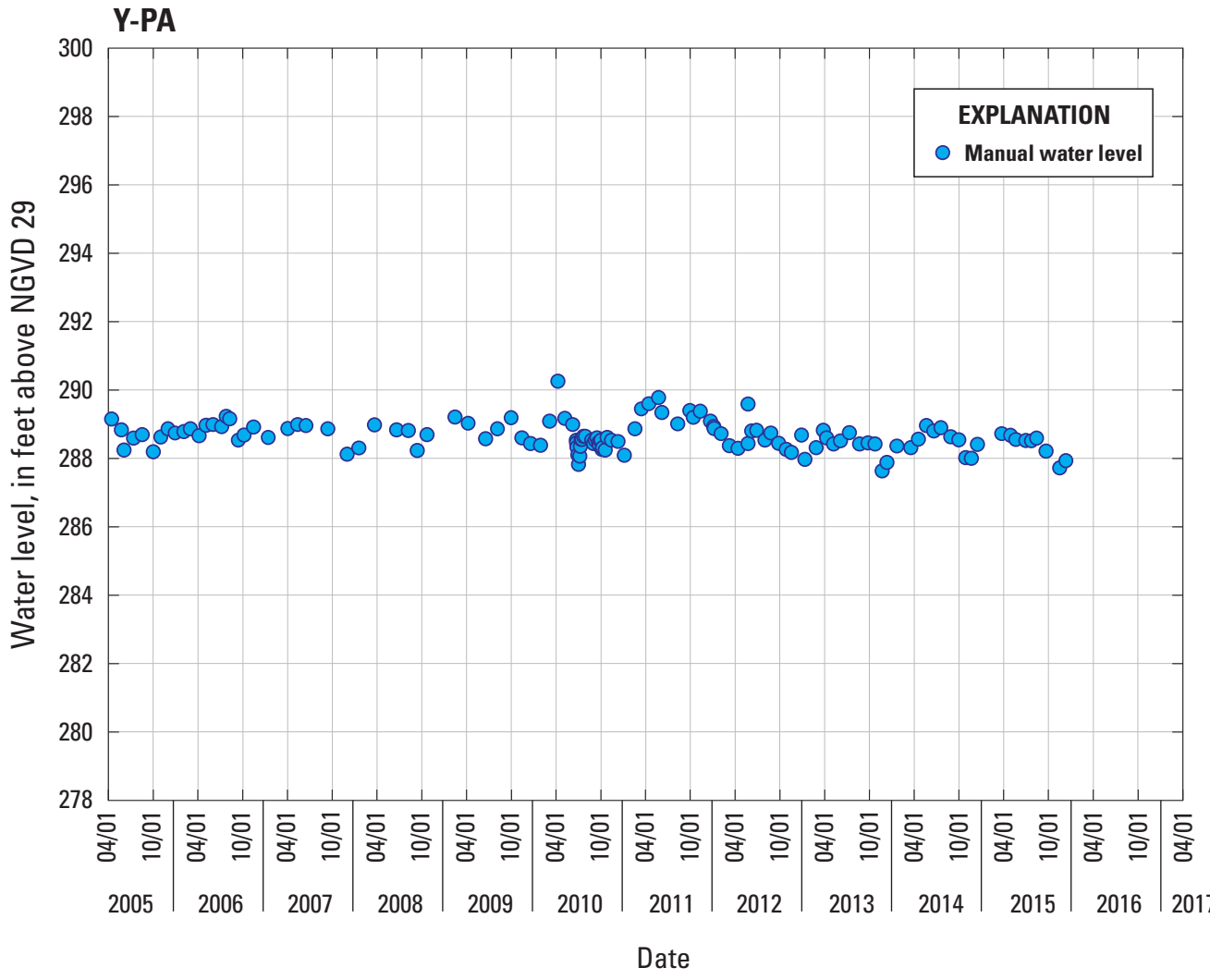

Figure 45. Discrete groundwater-level measurements for observation well Y-PA from an earthen dam site in southern Westchester County, New York. Gaps in groundwater-level record indicate no data or a dry measurement. Location of well shown on figure 1; details are listed in table 1.

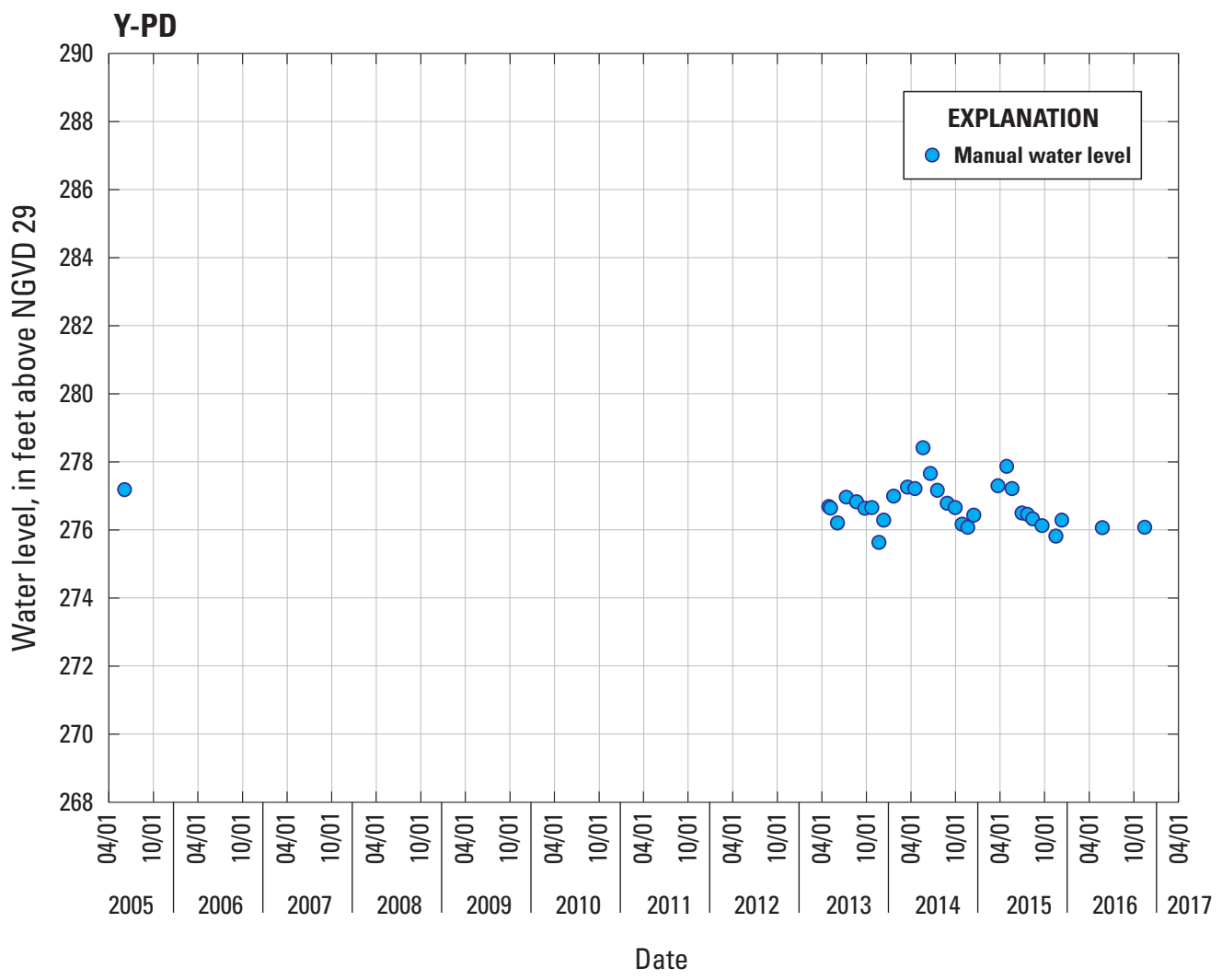

Figure 46. Discrete groundwater-level measurements for observation well Y-PD from an earthen dam site in southern Westchester County, New York. Gaps in groundwater-level record indicate no data or a dry measurement. Location of well shown on figure 1; details are listed in table 1. 


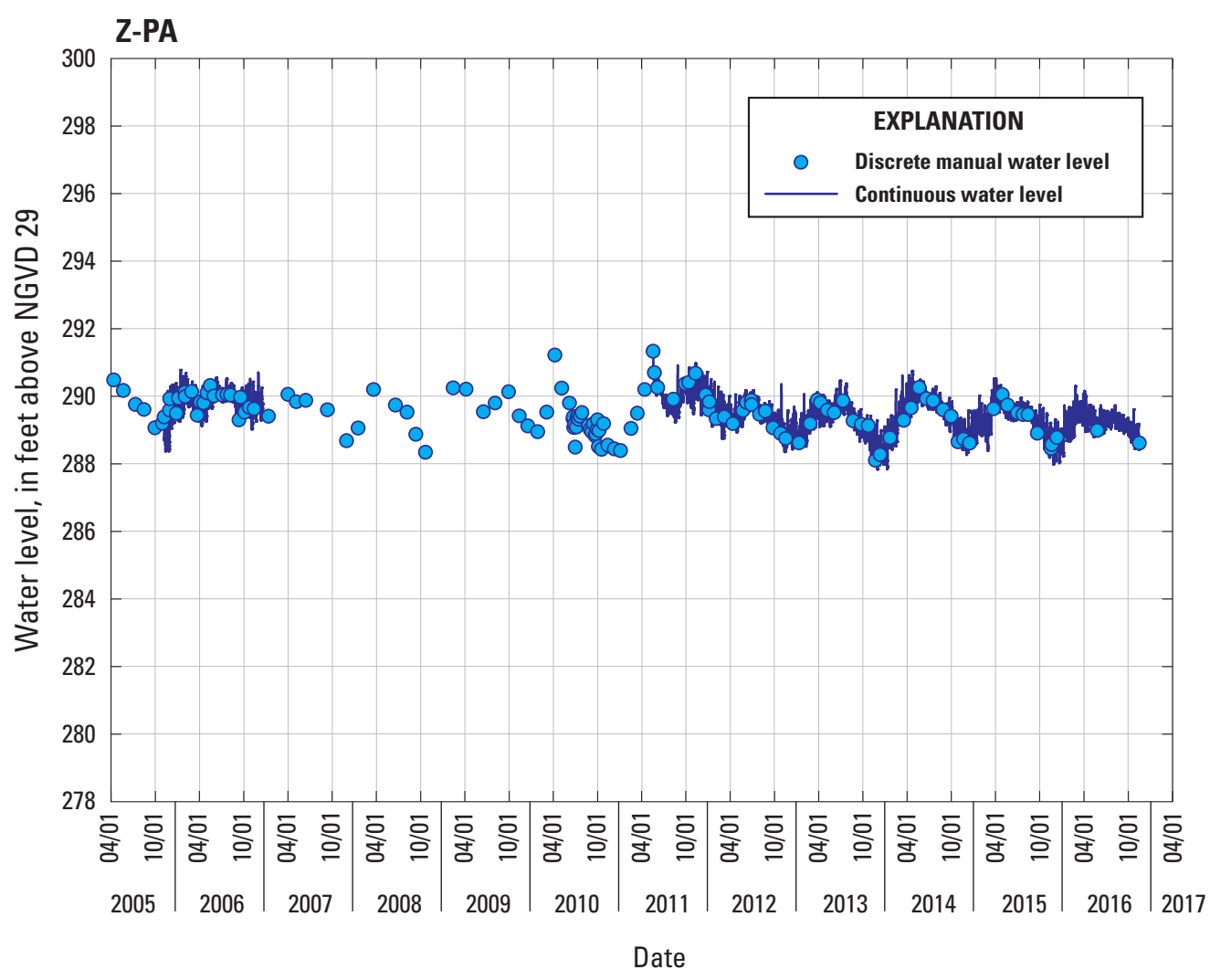

Figure 47. Discrete and continuous-record groundwaterlevel measurements for observation well Z-PA from an earthen dam site in southern Westchester County, New York. Gaps in groundwater-level record indicate no data or a dry measurement. Location of well shown on figure 1 ; details are listed in table 1.

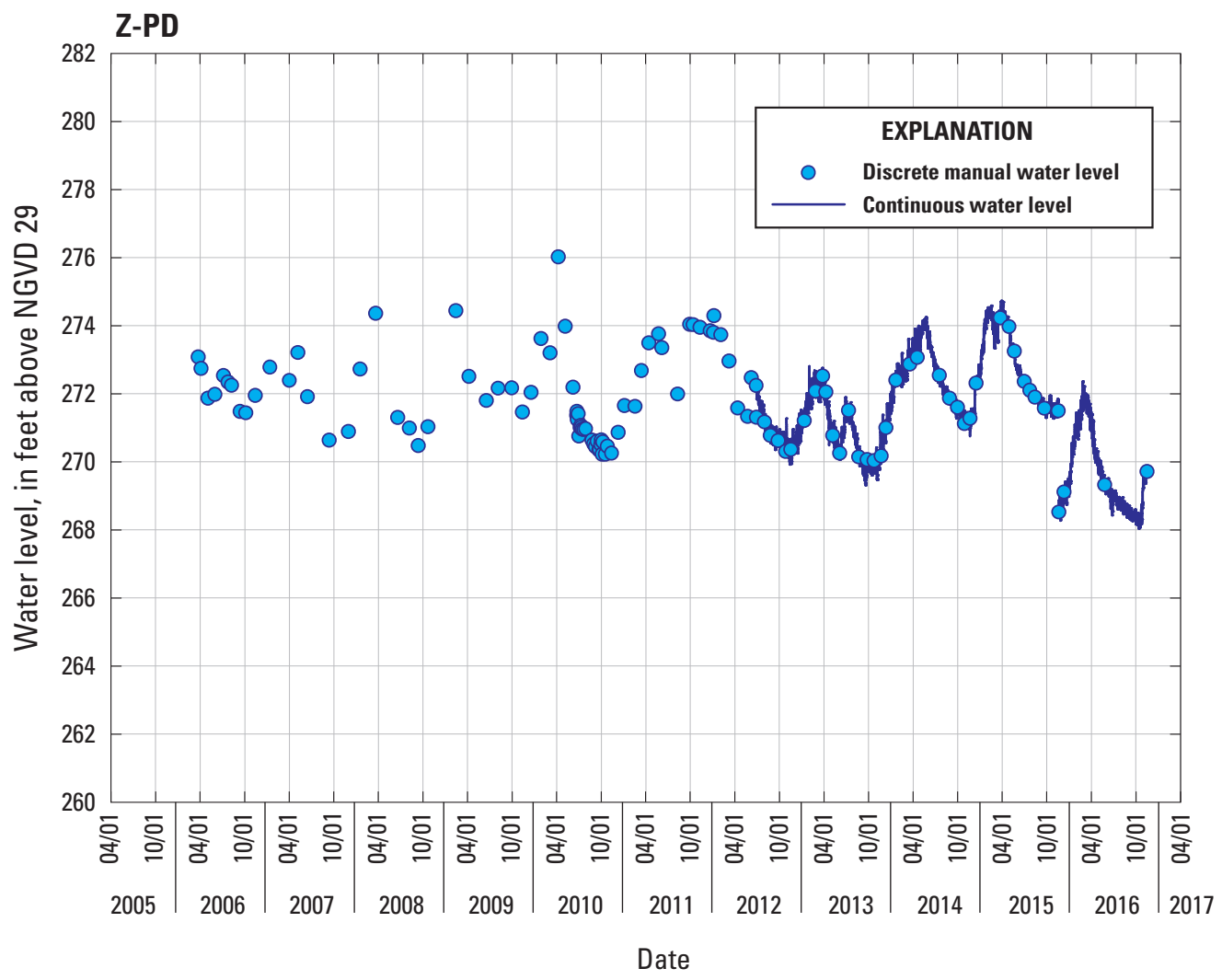

Figure 48. Discrete and continuous-record groundwaterlevel measurements for observation well Z-PD from an earthen dam site in southern Westchester County, New York. Gaps in groundwater-level record indicate no data or a dry measurement. Location of well shown on figure 1; details are listed in table 1. 


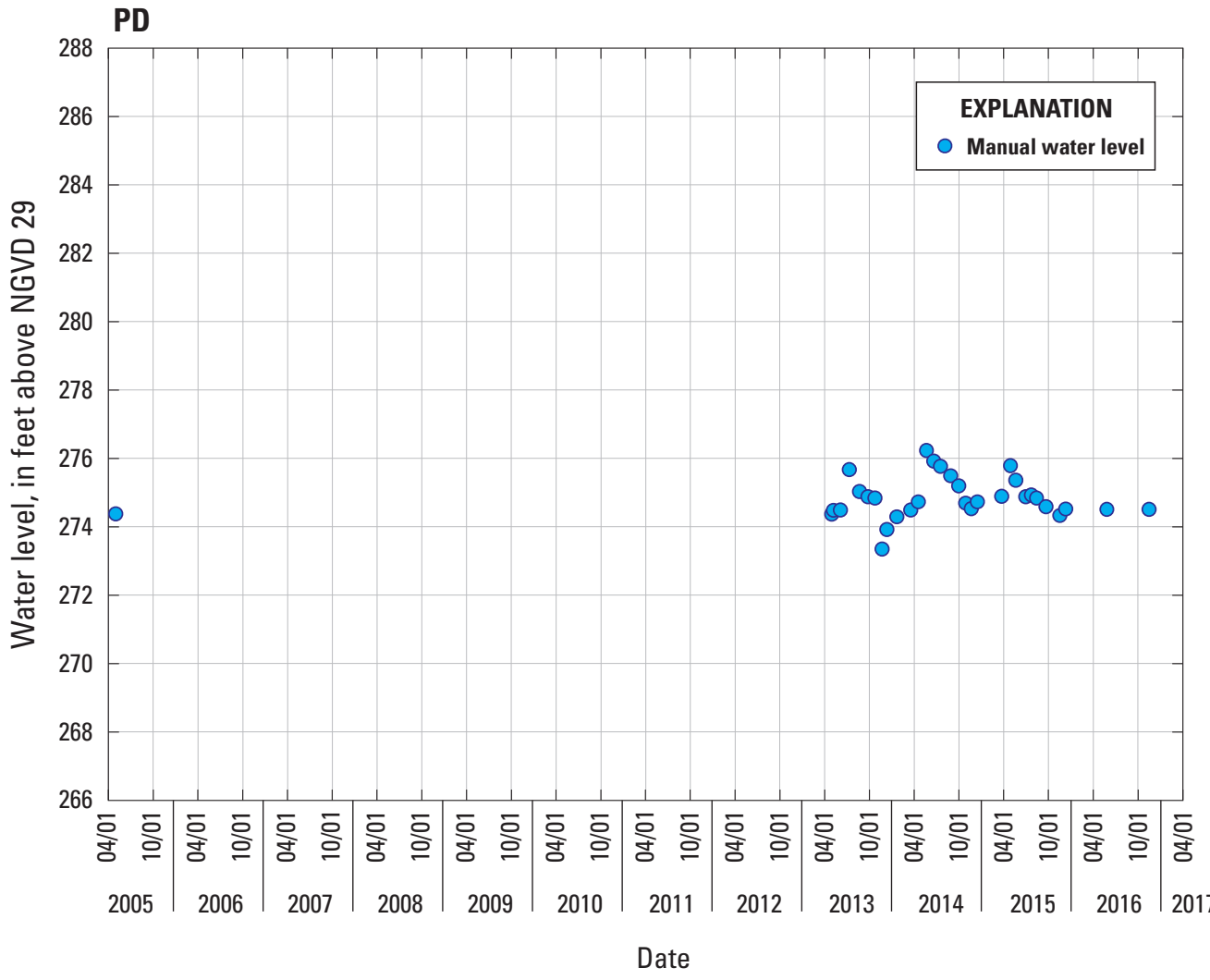

Figure 49. Discrete groundwater-level measurements for observation well PD from an earthen dam site in southern Westchester County, New York. Gaps in groundwaterlevel record indicate no data or a dry measurement. Location of well shown on figure 1; details are listed in table 1.

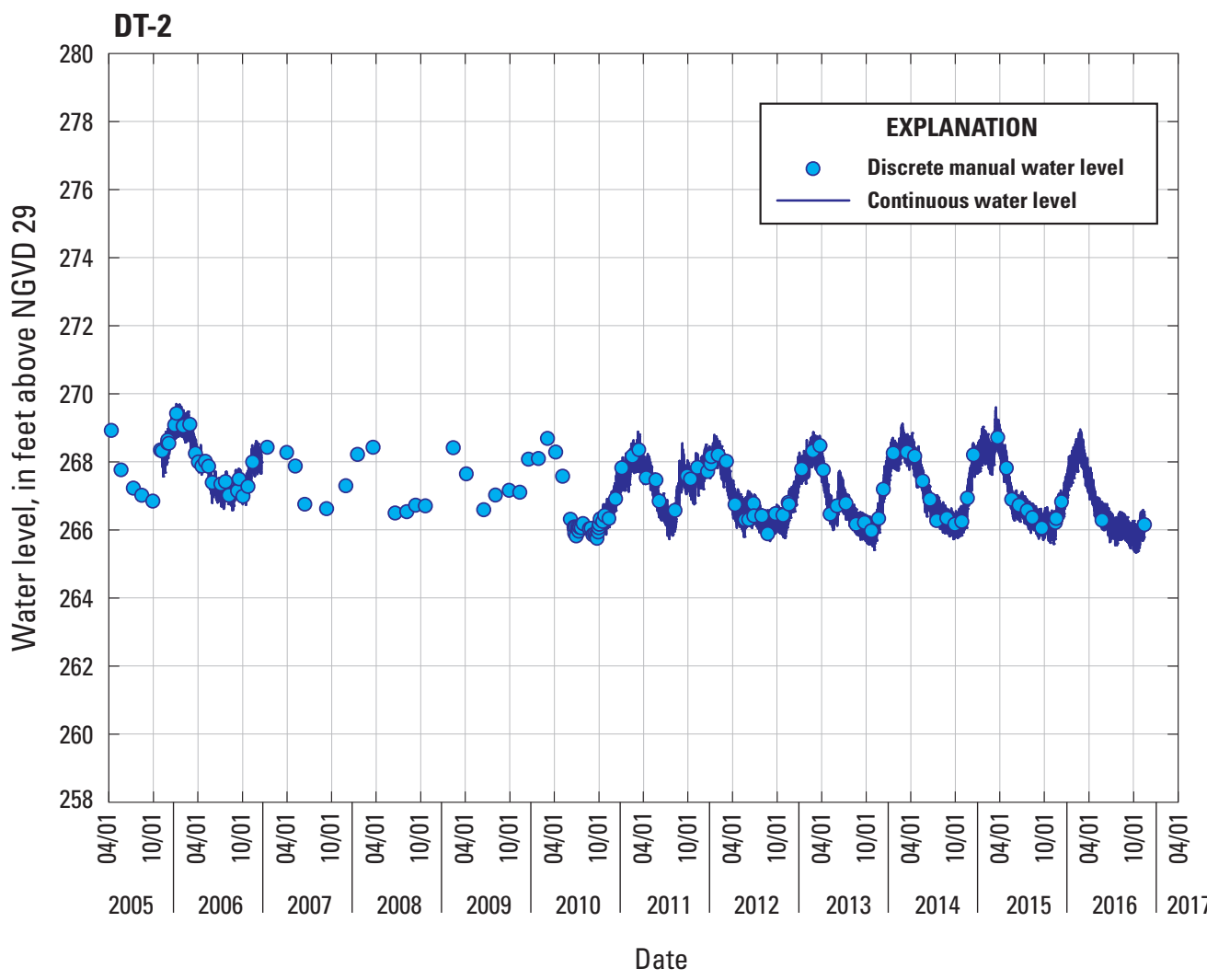

Figure 50. Discrete and continuous-record groundwaterlevel measurements for observation well DT-2 from an earthen dam site in southern Westchester County, New York. Gaps in groundwater-level record indicate no data or a dry measurement. Location of well shown on figure 1; details are listed in table 1. 


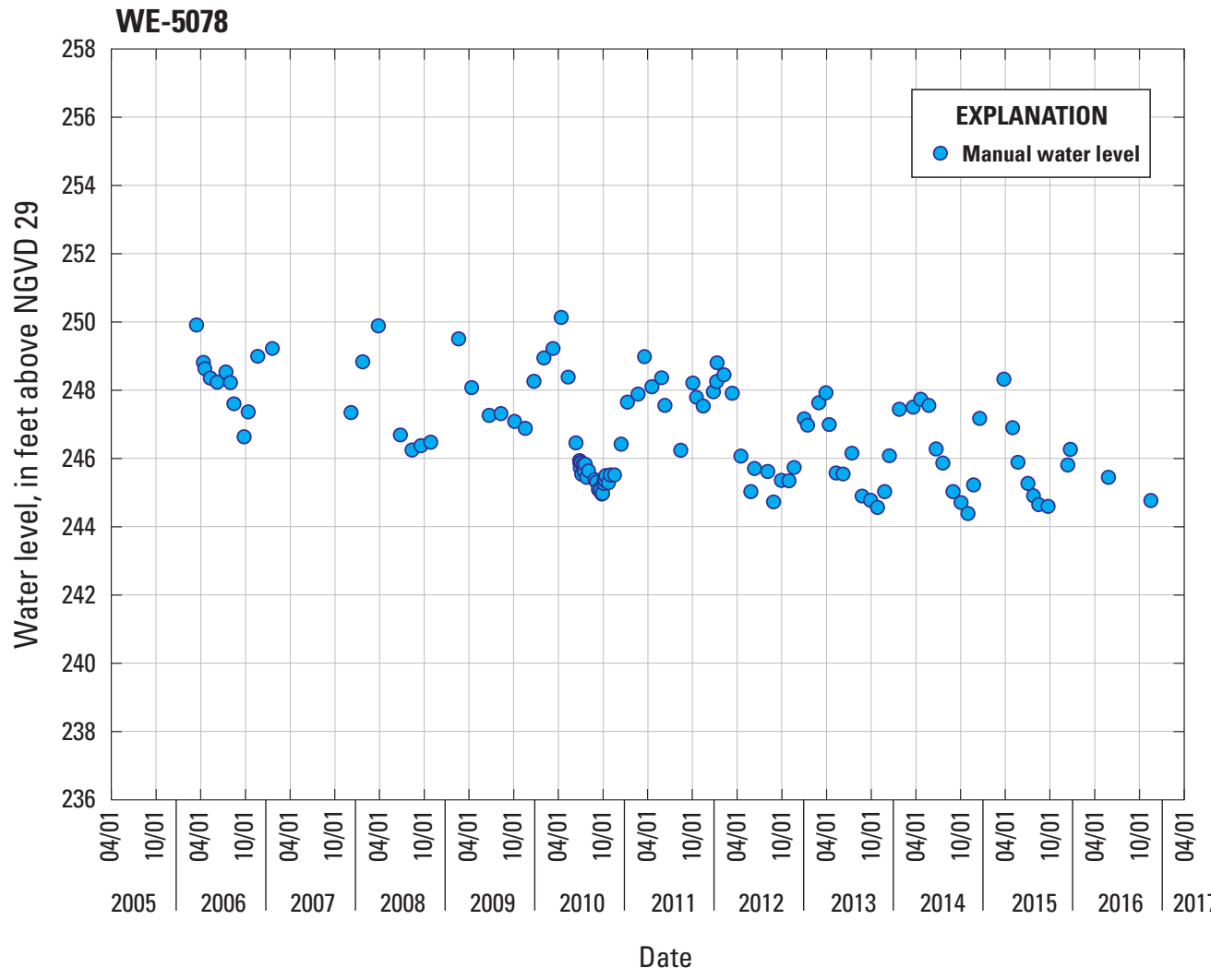

Figure 51. Discrete groundwater-level measurements for observation well WE-5078 from an earthen dam site in southern Westchester County, New York. Gaps in groundwater-level record indicate no data or a dry measurement. Location of well shown on figure 1 ; details are listed in table 1.

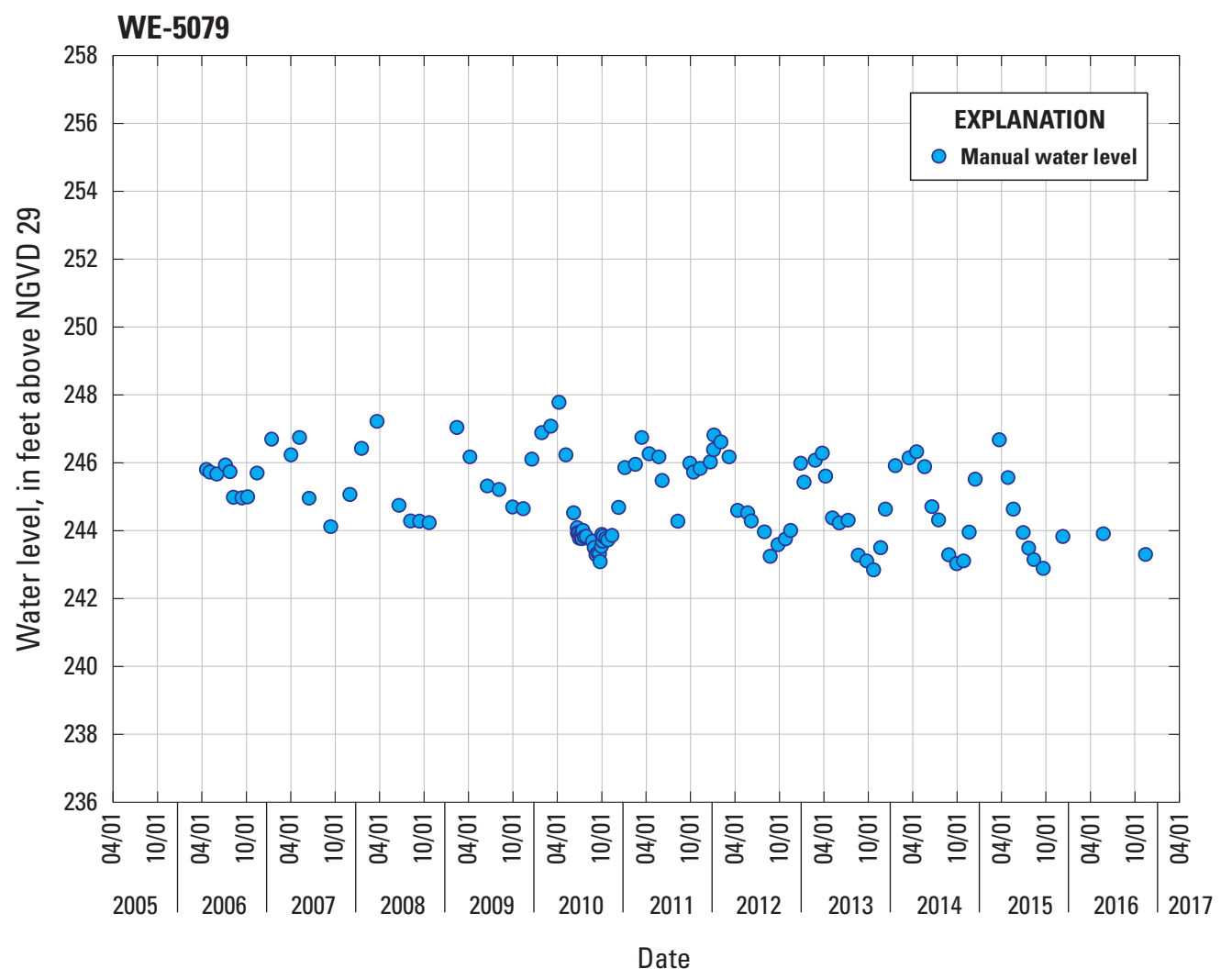

Figure 52. Discrete groundwater-level measurements for observation well WE-5079 from an earthen dam site in southern Westchester County, New York. Gaps in groundwater-level record indicate no data or a dry measurement. Location of well shown on figure 1; details are listed in table 1. 


\section{Appendix 1. Discrete and Continuous-Record Groundwater-Level Measurements for Observation Wells in Bronx and Westchester Counties, New York}

The data in tables 1.1 through 1.50 are replicated from the U.S. Geological Survey National Water Information System (U.S. Geological Survey, 2016) and can be downloaded at https://doi.org/10.3133/ds1075. 

For more information about this report, contact: Director, New York Water Science Center U.S. Geological Survey

2045 Route 112, Building 4

Coram, NY 11727

dc_ny@usgs.gov

(518) 285-5602

or visit our website at https://ny.water.usgs.gov

Publishing support provided by the

Pembroke Publishing Service Center 


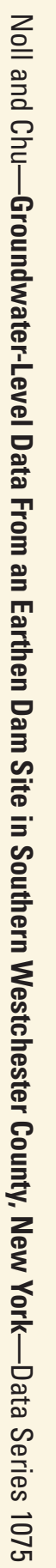

